\author{
UNIVERSIDADE DE SÃO PAULO \\ INSTITUTO DE ENERGIA E AMBIENTE \\ PROGRAMA DE PÓS-GRADUAÇÃO EM ENERGIA
}

THAINÁ RODRIGUES DE SÁ

O PROCESSO DE LICENCIAMENTO AMBIENTAL DE USINAS

SOLARES FOTOVOLTAICAS NO BRASIL

SÃO PAULO

2020 


\section{O PROCESSO DE LICENCIAMENTO AMBIENTAL DE USINAS SOLARES FOTOVOLTAICAS NO BRASIL}

Dissertação apresentada ao Programa de PósGraduação em Energia do Instituto de Energia e Ambiente da Universidade de São Paulo para a obtenção do título de Mestre em Ciências.

Orientador: Prof. Dr. Roberto Zilles

Versão Corrigida

\section{SÃO PAULO}


AUTORIZO A REPRODUÇÃO E DIVULGAÇÃO TOTAL OU PARCIAL DESTE TRABALHO, POR QUALQUER MEIO CONVENCIONAL OU ELETRÔNICO, PARA FINS DE ESTUDO E PESQUISA, DESDE QUE CITADA A FONTE.

FICHA CATALOGRÁFICA

Sá, Thainá Rodrigues de.

O processo de licenciamento ambiental de usinas solares fotovoltaicas no Brasil. / Thainá Rodrigues de Sá; orientador: Roberto Zilles.-- São Paulo, 2020.

105 f.: il., $30 \mathrm{~cm}$.

Dissertação (Mestrado em Ciências) - Programa de PósGraduação em Energia - Instituto de Energia e Ambiente da Universidade de São Paulo.

1. Sistemas fotovoltaicos. 2. Energia solar. 3. Licenciamento ambiental. I. Título 
Nome: SÁ, Thainá Rodrigues de

Título: O processo de licenciamento ambiental de usinas solares fotovoltaicas no Brasil

Dissertação apresentada ao Programa de PósGraduação em Energia do Instituto de Energia e Ambiente da Universidade de São Paulo para a obtenção do título de Mestre em Ciências.

Aprovada em: 10 de dezembro de 2020.

Banca Examinadora

Prof. Dr. Roberto Zilles

Instituição: Instituto de Energia e Ambiente IEE-USP

Profa. Dra. Virgínia Parente de Barros Instituição: Instituto de Energia e Ambiente IEE-USP

Prof. Dr. Tercio Ambrizzi

e Ciências Atmosféricas - IAG-USP

Prof. Dr. João Tavares Pinho UFPA
Instituição: Instituto de Astronomia, Geofísica Instituição: Universidade Federal do Pará - 


\section{AGRADECIMENTOS}

Aos meus pais, que com muita dedicação, carinho e esforço buscaram me proporcionar a melhor educação que puderam, que me apoiam em todas as dificuldades e alegrias da vida.

Aos meus irmãos, que fazem os dias serem mais leves e alegres e que sempre me apoiam em todas as situações.

Ao meu marido, que sempre me impulsiona a ser a melhor versão de mim mesma e me apoiou muito durante toda a graduação e pós-graduação, com muito carinho, honestidade e amor.

À coordenadora da área socioambiental da empresa Quadran Brasil Participações LTDA, Juliana Louyza de Souza Cavalquante Aquino, que me auxiliou muito para entender o processo de licenciamento ambiental no estado do Ceará.

Ao Prof. Dr. Roberto Zilles, por toda a dedicação, aprendizado, esforço e por ter contribuído muito para meu crescimento científico.

Ao Instituto de Energia e Ambiente, pela oportunidade de realização do curso de mestrado. 


\section{RESUMO}

A geração de energia elétrica a partir da fonte solar é bastante promissora. Isso se deve ao fato de que a busca por fontes renováveis é cada vez mais intensa, uma vez que os recursos finitos, como derivados de petróleo etc, estão se tornando mais escassos e novos projetos de hidrelétricas estão cada vez menos factíveis de serem desenvolvidos por questões ambientais. Diante dessas circunstâncias, o desenvolvimento de alternativas de menor impacto sobre o meio ambiente está na agenda da expansão do sistema de produção de energia elétrica. A produção de energia elétrica, através da conversão direta da radiação solar em eletricidade, com sistemas fotovoltaicos, apresenta-se como uma das alternativas. Contudo, a implantação e a operação de sistemas fotovoltaicos não estão livres de impactos ambientais associados com a adequação da área ocupada e com as movimentações logísticas da implantação e da operação dos sistemas. O processo de licenciamento ambiental para a implantação e operação de usinas fotovoltaicas não está amplamente estudado e há poucas referências. Nesse sentido, este trabalho faz uma análise do processo de licenciamento ambiental praticado no estado do Ceará, que possui um protocolo para o licenciamento ambiental de empreendimentos fotovoltaicos. A partir dessa análise, apresenta os principais obstáculos enfrentados, lacunas existentes e orientações para a elaboração de protocolos para licenciamento ambiental de usinas fotovoltaicas. Dentre os principais problemas encontrados, pode-se citar o conflito de competências, a ausência de normativa federal, deficiência de conhecimento técnico científico e a existência de um vínculo contratual entre a empresa executora do relatório ambiental e o interessado no empreendimento. Para que os obstáculos sejam resolvidos sugere-se a aprovação de normas que definam as competências atribuídas a cada esfera, regulamentação dos princípios do direito ambiental, criação de cursos específicos de tecnologia solar e passar o processo de licenciamento ambiental a um órgão independente, sem vínculo contratual com os interessados no empreendimento.

Palavras-chave: licenciamento ambiental, tecnologia solar fotovoltaica, usinas solares 


\begin{abstract}
The generation of electric energy from the solar source is very promising. This is due to the fact that the search for renewable sources is increasingly intense, since finite resources, such as oil products etc., are becoming scarcer and new hydroelectric projects are less and less feasible to be developed due to environmental issues. Under these circumstances, the development of alternatives with less impact on the environment is on the agenda for the expansion of the electricity production system. The production of electric energy, through the direct conversion of solar radiation into electricity, with photovoltaic systems, presents itself as one of the alternatives. However, the deployment and operation of photovoltaic systems are not free from environmental impacts associated with the adequacy of the occupied area and with the logistical movements of the implantation and operation of the systems. The environmental licensing process for the installation and operation of photovoltaic plants is not widely studied and there are few references. In this way, this work analyzes the environmental licensing process practiced in the state of Ceará, which has a protocol for the environmental licensing of photovoltaic projects. From this analysis, it presents the main obstacles faced, existing gaps and guidelines for the elaboration of protocols for environmental licensing of photovoltaic plant. Among the main problems encountered, it is mentioned the conflict of competences, the absence of federal regulations, deficiency of technical scientific knowledge and the existence of a contractual tie between the company that executes the environmental report and the person interested in the enterprise. In order for the obstacles to be resolved, it is suggested the approval of norms that define the competences attributed to each sphere, regulation of the principles of environmental law, creation of specific courses in solar technology and pass the process of environmental licensing to an independent agency, without contractual bond with those interested in the enterprise.
\end{abstract}

Keywords: environmental licensing, solar photovoltaic technology, solar plants 


\section{LISTA DE FIGURAS}

Figura 1 - Localização de empreendimentos de geração centralizada de energia solar

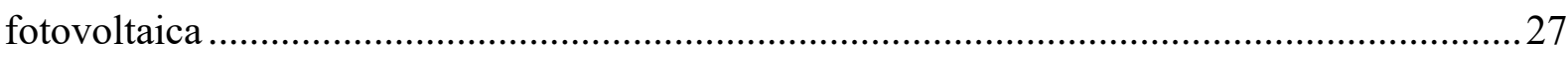

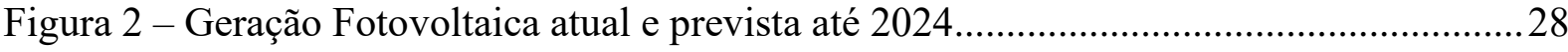

Figura 3 - Conteúdo mínimo do Estudo de Impacto Ambiental (EIA) ................................... 43

Figura 4 - Conteúdo mínimo do Relatório de Impacto ao Meio Ambiente (RIMA)................44

Figura 5 - Processo de Licenciamento Ambiental ..................................................................... 45

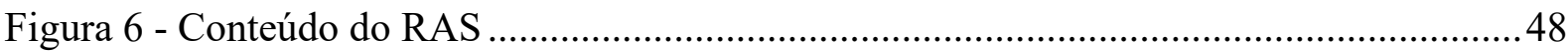

Figura 7 - Total diário da irradiação no plano inclinado na latitude - média anual ................ 61

Figura 8 - Total diário da irradiação no plano inclinado na latitude ........................................62

Figura 9 - Participação do Ceará no montante de potência instalada da fonte solar ................63 


\section{LISTA DE TABELAS}

Tabela 1 - Unidades Consumidoras com Geração Distribuída.............................................26

Tabela 2- Principais aspectos e impactos ambientais relacionados às usinas fotovoltaicas (UFV) 57

Tabela 3 - Usinas solares em operação no Ceará. 63

Tabela 4 - Instrumentos legais que embasam os processos de licenciamento para intervenção

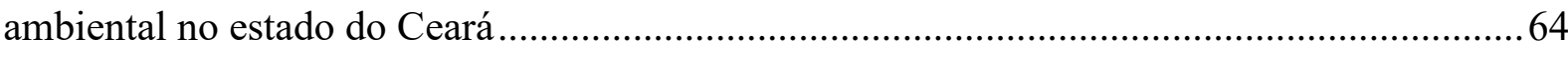
Tabela 5 - Critérios para o licenciamento ambiental de empreendimentos de micro e mini

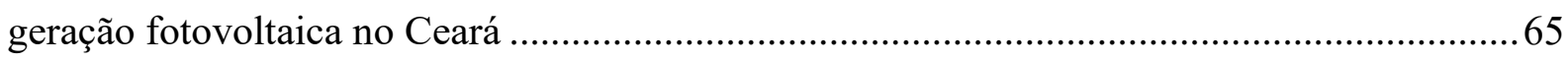

Tabela 6 - Potencial poluidor de empreendimentos de energia solar fotovoltaica ...................66 


\section{LISTA DE ABREVIATURAS, SÍMBOLOS E SIGLAS}

ACL Ambiente de Contratação Livre

ACR Ambiente de Contratação Regulada

ADA Área Diretamente Afetada

AIA Avaliação de Impacto Ambiental

AID Área de Influência Direta

AII Área de Influência Indireta

ANEEL Agência Nacional de Energia Elétrica

BNDES Banco Nacional de Desenvolvimento Econômico e Social

CCEE Câmera de Comercialização de Energia Elétrica

CEAA Canadian Environmental Assessment Agency

CEQ Council on Environmental Quality

CF Constituição Federal

CMSA Conselho Superior do Meio Ambiente

COEMA/CE Conselho Estadual do Meio Ambiente

CONAMA O Conselho Nacional do Meio Ambiente

CONPAM Conselho de Políticas e Gestão do Meio Ambiente

COSEMA Conselho Estadual de Meio Ambiente

EIA Estudo de Impacto Ambiental

EIA Environmental Impact Assessment

EIR Environmental Impact Report

EPA Environmental Protection Agency

EPE Empresa de Pesquisa Energética

EPBC Environment Protection and Biodiversity Conservation Act

FV Fotovoltaico

GAMA Gerência Adjunta do Meio Ambiente

GD Geração Distribuída

IBAMA Instituto Brasileiro do Meio Ambiente e dos Recursos Naturais Renováveis

ICMS Imposto sobre Circulação de Mercadorias e Prestação de Serviços

INCT-MC Instituto Nacional de Ciência e Tecnologia para Mudanças Climáticas

INPE Instituto Nacional de Pesquisas Espaciais

IPI Imposto sobre Produtos Industrializados

LER Leilão de Energia de Reserva 
LI Licença de Instalação

LO Licença de Operação

LP Licença Prévia

LRET Large-scale Renewable Energy Target

MIGDI Microssistema isolado de geração e distribuição de energia elétrica

MMA Ministério do Meio Ambiente

MME Ministério de Minas e Energia

MoEF Ministry of Environment, Forest

NEPA National Environmental Policy Act

OEMAs Órgãos Estaduais de Meio Ambiente

OMMAs Órgãos Municipais de Meio Ambiente

ONS Operador Nacional do Sistema Elétrico

PADIS Programa de Apoio ao Desenvolvimento Tecnológico da Indústria de Semicondutores

PCA Plano de Controle Ambiental

CPCB Conselho de Controle de Poluição

PNRS Política Nacional dos Resíduos Sólidos

PRODEEM Programa de Desenvolvimento Energético de Estados e Municípios

PROESCO Projetos de Eficiência Energética

PROINFA Programa de Incentivo às Fontes Alternativas de Energia Elétrica

RAS Relatório Ambiental Simplificado

REA Renewable Energy Approval

RIMA Relatório de Impacto ao Meio Ambiente

SEMACE Superintendência Estadual do Meio Ambiente

SILIS Sistema de Licenciamento Simplificado

SISNAMA Sistema Nacional de Meio Ambiental

SNUC Sistema Nacional de Unidades de Conservação

SUDAM Superintendência do Desenvolvimento da Amazônia

SUDECO Superintendência do Desenvolvimento do Centro-Oeste

SUDENE Superintendência do Desenvolvimento do Nordeste

TUSD Tarifas de Uso dos Sistemas de Distribuição

TUST Tarifas de Uso dos Sistemas de Transmissão

UCs Unidades de Conservação 
UFIRCE Unidade Federal de Referência

USEPA United States Environmental Protection Agency

ZCAS Zona de Convergência do Atlântico Sul

ZCIT Zona de Convergência Intertropical 


\section{SUMÁRIO}

1. INTRODUÇÃ

2. ENERGIA SOLAR FOTOVOLTAICA NO BRASIL .......................................... 24

2.1 Panorama Brasileiro de Energia Solar Fotovoltaica.......................................25

2.2 Influência da Meteorologia na Geração de Energia Fotovoltaica no Brasil ........ 28

2.3 Incentivos à Energia Solar Fotovoltaica no Brasil ......................................... 30

3. DIREITO NO BRASIL VOLTADO AO LICENCIAMENTO AMBIENTAL ........ 36

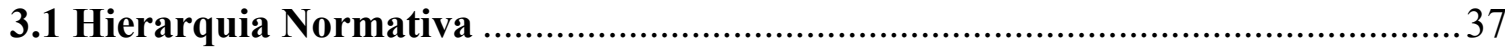

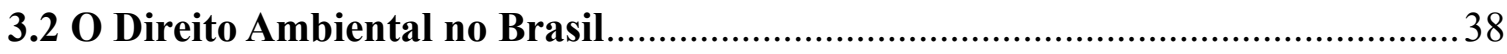

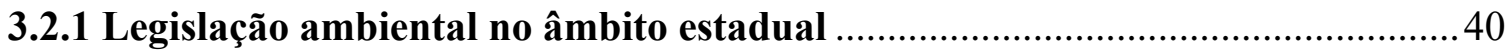

4. LICENCIAMENTO AMBIENTAL NO BRASIL ........................................ 41

4.1 Roteiro para Elaboração de Estudos Ambientais............................................ 49

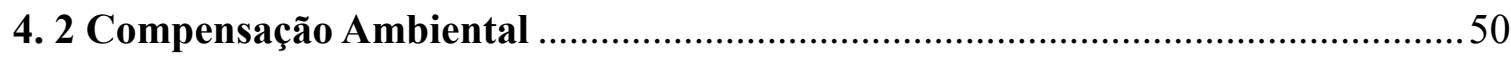

4.3 Os Impactos Ambientais Atrelados às Usinas Solares Fotovoltaicas ....................56

5. ESTUDO DE CASO: EMPREENDIMENTOS DE GERAÇÃO DE ENERGIA ELÉTRICA SOLAR FOTOVOLTAICA NO ESTADO DO CEARÁ........................... 60

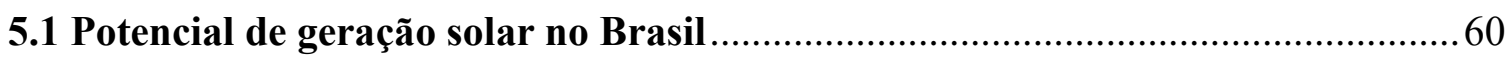

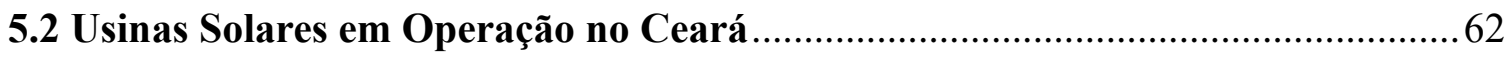

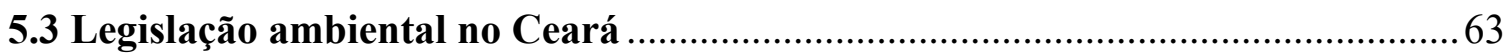

5.4 Resoluções Normativas para Licenciamento Ambiental no Ceará de projetos de

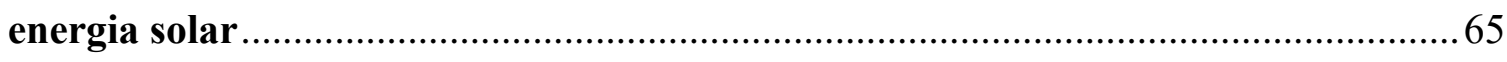

5.5 O Processo de Licenciamento de Usinas Solares Fotovoltaicas no Ceará .............68

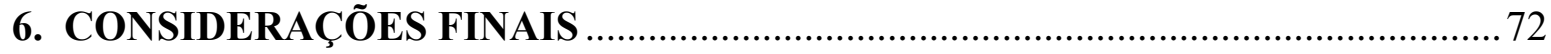

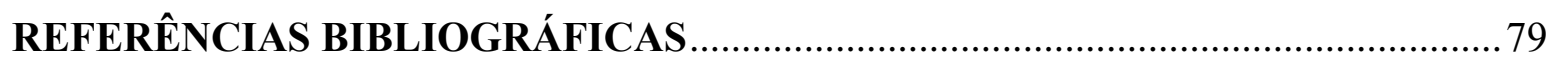

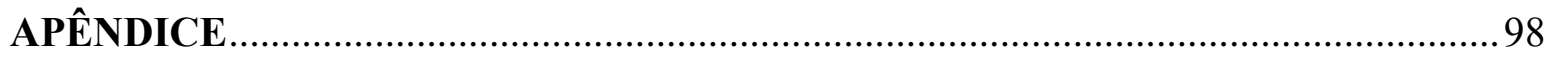




\section{INTRODUÇÃO}

O licenciamento ambiental é um tema que ainda se encontra em desenvolvimento no Brasil e gera muitos conflitos, além de haver problemas estruturais, de fiscalização e que necessitam de mais estudos e soluções (GOMES e SILVA, 2017).

É um processo administrativo pelo qual o órgão ambiental licencia a localização, instalação, ampliação, modificação e a operação de empreendimentos/atividades que utilizam os recursos ambientais e são considerados efetiva ou potencialmente poluidores ou àqueles que, sob qualquer forma, possam causar degradação ambiental. Com este instrumento, busca-se garantir que as medidas preventivas e de controle adotadas nos empreendimentos sejam compatíveis com o desenvolvimento sustentável (GOMES e SILVA, 2017).

A análise de processos de licenciamento ambiental em outros países é interessante de ser feita, para termos comparativos com o Brasil. Como exemplos foram analisados os processos de licenciamento na Alemanha, por conta de ser uma potência mundial, um dos países líderes e de referência do bloco europeu, engajado em questões ambientais e um dos principais expoentes da tecnologia fotovoltaica; os EUA, outra grande potência mas com perfil mais pragmático em muitos estados em relação às questões ambientais, além de possuir uma parcela significativa da tecnologia no país, mesmo sendo um dos países mais poluidores de todos; Canadá, China, Austrália e Índia também, para entender os desafios que são enfrentados nesse processo em expansão em diferentes países.

- Alemanha:

Na Alemanha, a proteção ambiental começou a ser visada por volta dos anos 1970, com a criação de diversos departamentos de meio ambiente em alguns ministérios até que tudo fosse unificado com o Ministério do Meio Ambiente, em 1986. Mais tarde, em 1990, muitas leis para a defesa do meio ambiente, das águas, controle de resíduos e licenciamento ambiental foram aprovadas. Nos dias atuais, como a Alemanha está inserida na União Europeia, também está absorvendo as leis do bloco, além das nacionais. Entretanto, as normas do país para emissões de licenças ambientais são mais rígidas do que as do bloco europeu (REIS, 2015). 
Como orientações da política ambiental na República Federal da Alemanha estão inclusos alguns princípios: a) da prevenção, buscando evitar o impacto, dano ou perigo ambiental ao invés de repará-lo através de normas e limites de emissões para assegurar a qualidade ambiental, de modo que tais impactos não atinjam ou prejudiquem o homem e a natureza como um todo, sendo então considerados como um conjunto, não separadamente; b) da cooperação, como o nome diz visa a colaboração dos agentes interessados na atividade, de modo a evitar degradação e danos ambientais; c) e do poluidor-pagador, sendo que independente de quem tenha causado impacto ambiental deve pagar pelas consequências (CARVALHO, 1998).

A Lei de Avaliação de Impacto Ambiental define os casos para os quais uma AIA (Avaliação de Impacto Ambiental) é necessária e regula as leis federais de licenciamento ambiental. A lei é aplicável a projetos de energia renovável envolvendo energia eólica e biogás, entre outros projetos. Entretanto, a geração de energia solar fotovoltaica não é mencionada. Para este tipo de empreendimento, a aprovação é realizada pelo respectivo município, que vai determinar se o projeto não viola nenhuma de suas restrições de zoneamento (HOFFMANN et al. 2019).

Para que se evite conflitos com áreas protegidas ambientalmente, já que a fauna e a flora podem ser significativamente afetadas, os municípios são incentivados a priorizar algumas áreas para a instalação de usinas solares fotovoltaicas, avaliando fatores locais. Para isso, é exigido que o município faça uma avaliação do impacto ambiental da atividade, para o zoneamento da instalação de usinas solares fotovoltaicas. Tais empreendimentos podem ser instalados e operados em áreas prioritárias com apenas uma licença municipal simplificada (HOFFMANN et al. 2019).

Entretanto, há cláusulas específicas que fazem a exigência de compensação ambiental por perturbar o meio de alguma forma, aplicadas assim dependendo do caso específico e de acordo com as condições locais (HOFFMANN et al. 2019).

Para garantir a segurança do meio ambiente, a competência é dividida entre os entes federal, regional e municipal. A Agência Ambiental Alemã é a responsável pela avaliação dos impactos ambientais, entretanto grande parte dos projetos tem a condução dos agentes regionais (REIS, 2015). 
A definição de procedimentos das atividades, normas de emissões e padrões de qualidade está sob responsabilidade do ente federal, ou seja, é responsável pela organização legislativa, enquanto os estados são os executores (REIS, 2015).

Para pedir uma licença deve-se seguir alguns procedimentos, tais como: o pedido por escrito; elaboração de documentos técnicos; publicação no Diário Oficial e jornal diário; apresentação para inspeção durante dois meses para os interessados; e aviso por escrito da autorização (CARVALHO, 1998).

Para empreendimentos que apresentam um menor potencial de impacto, como instalações menores e baixos níveis de emissões aplica-se um licenciamento simplificado (REIS, 2015).

De modo a assessorar o processo, há alguns órgãos técnicos e científicos do Ministério Ambiental: a agência federal de Proteção Ambiental e as instituições estatais de proteção ambiental, que concedem pareceres científicos para o ministério, como para o licenciamento ambiental e a supervisão dos órgãos. Ainda, para suportar os estudos de licenciamento para essas instituições, há algumas organizações como a TÜV ou mesmo peritos independentes, aceitos e reconhecidos pelo governo, especializados e qualificados e que não possuem então vínculo com o empreendedor, garantindo então imparcialidade no processo (REIS, 2015).

\section{- Estados Unidos}

Nos EUA, uma análise crítica sobre a forma como trata das questões ambientais é muito interessante de ser feita, uma vez que é um país altamente industrializado e poluidor. Apesar disso, o país não é signatário do protocolo de Kyoto e saiu do acordo de Paris. Entretanto, por ser uma república federativa, os estados possuem regulamentação própria e podem então ter mais controle sobre eles mesmos, portanto muitos estados estão adotando, voluntariamente, metas e medidas para redução de gases que contribuem para o aquecimento global.

No âmbito federal, o órgão responsável pelas questões ambientais é a Agência de Proteção Ambiental (EPA), já no âmbito estadual muitos estados possuem suas próprias agências com o mesmo objetivo, com funções executoras. Ou seja, as questões ambientais são divididas entre os âmbitos federal, estadual e municipal. Baseada na Lei de Proteção Ambiental de 1969, a legislação ambiental dos EUA é complementada por outras, como em 1970 pela lei do Ar 
Limpo, em 1976 pela lei da gestão florestal e da Conservação dos Recursos e Recuperação e em 1977 pela lei da Água Limpa, entre muitas outras (REIS, 2015).

A Política Nacional de Meio Ambiente (National Environmental Policy Act - NEPA) foi instituída pelo ato $\mathrm{n}^{\mathrm{o}} 49$ e marcou assim o efetivo início dos atos para proteção ao meio ambiente. Como suas principais funções pode-se destacar: descrição de políticas e dos objetivos para regulamentação nacional das questões ambientais; exigência de que nas tomadas de decisões as agências federais considerem os impactos ambientais e seus efeitos (PERCIVAL, 2020).

Através do mesmo decreto, criou-se também o Conselho de Qualidade Ambiental dos EUA (Council on Environmental Quality - CEQ), supervisionando a avaliação dos impactos ambientais pelas agências federais, atuando como árbitro em situações de discordância. Além deste, criou-se também a Agência de Proteção Ambiental Americana (United States Environmental Protection Agency - USEPA), que é responsável por: estabelecer padrões de qualidade; comandar o desenvolvimento técnico através de financiamento; elaborar e analisar os Relatórios de Impactos Ambientais a nível federal; acompanhar leis e regulamentações ambientais (REIS, 2015).

Em situações de impactos ambientais significativos, a NEPA exige que as agências federais tomem frente do problema, avaliando-os e informando ao público, que pode manifestar sua opinião sobre o licenciamento da atividade antes da tomada de decisão, sobre os possíveis impactos (REIS, 2015).

Há duas categorias de sistema legal na área ambiental: controle da poluição e outra de conservação dos recursos naturais, que são derivadas de muitos tratados internacionais. Para que haja um controle de emissões e para punir qualquer atividade de impacto ambiental além do permitido, utilizam-se as multas e punições no âmbito civil. Já existem diversas leis que criminalizam tais ações, por isso elas são demasiadamente importantes para a preservação do meio ambiente, mantendo um limite de degradação permitido e delimitando as formas como serão implementados tais empreendimentos que possam causar impactos negativos sobre o meio ambiente (HG LEGAL RESOURCES, 2013). Para isso, o governo americano implementa incentivos e cobra taxas, como recompensa e punição para as decisões tomadas. 
Em relação à projetos de energia, a autoridade responsável pela condução do processo de revisão ambiental é o Departamento de Energia, que avalia a necessidade de licenciamento e define os estudos ambientais aplicável às empresas (HOFFMANN et al. 2019).

Segundo a legislação, o licenciamento é desnecessário para empreendimentos de geração de energia solar que exigem uma área inferior ou igual a 4 hectares, quando as instalações se localizam em áreas antropizadas e aderem zoneamento local. Tais projetos fazem parte de um processo que é conhecido como Exclusão categórica (CATEX). Quando este não é aplicável, a área em questão é visitada para análise e então estima-se o impacto potencial nos meios social, biológico, geológico, hídrico e da qualidade do ar. Dessa forma, uma Avaliação Ambiental é feita e financiada pelo interessado no projeto. Caso feita a análise e constate que não há impacto significativo, emite-se uma Constatação de Não Significativa Declaração de Impacto. Caso contrário, uma Declaração de Impacto Ambiental (semelhante ao Estudo de Impacto Ambiental) é feita. Assim, a área da atividade é definida com relação à localização e extensão da área, sendo esses os principais critérios para os estudos ambientais (HOFFMANN et al. 2019).

Uma Declaração de Impacto Ambiental conjunta foi feita por instituições federais de seis estados dos Estados Unidos: Arizona, Colorado, Novo México, Califórnia, Nevada e Utah que são os mais adequados para a instalações de projetos de geração de energia solar, considerando seus índices solares. Tal Declaração define áreas que teriam um impacto ambiental menor associado à instalação de projetos de geração de energia solar, levando em conta os recursos naturais e sociais. Este projeto tem o objetivo de facilitar o desenvolvimento deste tipo de empreendimento no país (SOLAR ENERGY DEVELOPMENT PROGRAMMATIC EIS, 2018).

\section{- Canadá}

No Canadá, o processo de avaliação de projetos é realizado pela Canadian Environmental Assessment Agency (CEAA - Agência Canadense de Avaliação Ambiental), classificando projetos baseados na descrição, nas contribuições da sociedade civil, além de outros estudos que sejam relevantes. Assim, a agência decide se há a necessidade de um Environmental Impact Assessment (EIA - Avaliação de Impacto Ambiental) para o projeto. Caso haja, há dois tipos que podem ser realizados: uma avaliação padrão por um órgão responsável ou uma avaliação 
mais abrangente composto por uma série de especialistas que não têm conflitos de interesse (HOFFMANN et al. 2019).

Em relação aos projetos de energia renovável, estes não estão mais sujeitos à legislação vigente no país, mas sim à legislação específica de cada província. Segundo Bryansky et al., (2018), os projetos de energia solar e eólica no Canadá são regidos de acordo com diferentes níveis de regulamentação e critérios ambientais em todo o país. Como exemplo, a província de Ontario introduziu a Lei da Energia Verde, através da qual estabeleceu a Renewable Energy Approval (REA - Aprovação da Energia Renovável), aplicável a alguns projetos solares. De acordo com essa lei, instalações solares montadas no solo com capacidade superior a $10 \mathrm{~kW}$ necessitam de uma REA, consulta ao público e às comunidades indígenas, e avaliação e mitigação de seu impacto.

- China

$\mathrm{Na}$ China, os estudos ambientais são agrupados em três categorias: Environmental Impact Report (EIR - Relatório de Impacto Ambiental), aplicável a projetos com alto grau de impacto; um formulário EIR, aplicável a projetos de grau moderado de impacto; e um formulário de registro de impacto ambiental, aplicável a projetos com baixo grau de impacto. Cabe ao empreendedor contratar uma agência competente para definir a necessidade de um EIR completo. De modo geral, grandes projetos com impacto significativo ou projetos menores em uma área ambiental sensível requerem uma avaliação mais aprofundada (WANG et al., 2003).

Depois de feito o processamento do formulário de impacto ambiental, a agência responsável pelo processo de estudos ambientais realiza um estudo preliminar para saber qual tipo de análise deve ser realizada. Tal análise é feita com base em dois critérios principais: descarga de poluentes, analisando o volume, tipo e complexidade das substâncias em questão e possíveis sugestões para minimizar os impactos; e as áreas sensíveis existentes com base nas características ecológicas, arqueológicas e de importância cultural. Demais considerações como tamanho, produto e parâmetros ambientais do projeto são usadas para classificá-las em categorias de alto, moderado e baixo impacto (HOFFMANN et al. 2019).

- Austrália: 
De acordo com Martin e Rice (2015), a Austrália enfrenta desafios com relação à projetos de energia renovável, uma vez que não há uma abordagem política única para aprovações, autorizações e implementações de projetos. A permissão envolve os governos federal, estadual e municipal. O requerente deve enviar a atividade proposta para a autoridade responsável, que irá então encaminhar para o Ministro de Planejamento. Tal procedimento é regulado por um grande número de políticas e regulamentos dos âmbitos federal, estadual e municipal, além de legislação diversificada, como Large-scale Renewable Energy Target (LRET) e a Environment Protection and Biodiversity Conservation Act (EPBC)

O departamento de meio ambiente da Austrália gerencia a Lei EPBC, que descreve o processo de avaliação dos recursos ambientais e culturais, principalmente quando o local é de significativa importância ambiental para o país, como patrimônio mundial e nacional, habitats de espécies ameaçadas ou migratórias, áreas marinhas federais, entre outros. Caso o impacto seja apenas local, as licenças podem ser emitidas por governos estaduais ou municipais (HOFFMANN et al. 2019).

- Índia:

Em relação à Índia, na fase de planejamento todos os projetos de energia renovável devem ser relatados ao Ministry of Environment, Forest (MoEF - Ministério do Meio Ambiente e Florestas) e ao Pollution Control Board (PCB - Conselho de Controle de Poluição), correspondente ao âmbito estadual (HOFFMANN et al. 2019).

Na fase inicial de um projeto, a notificação da AIA (2006) e suas emendas devem ser aplicadas de modo que se avalie a necessidade de autorização ambiental (CE, licença ou permissão). O MoEF, em 2016, em consulta com o Conselho Central de Controle de Poluição, reclassificou as indústrias, definindo um índice de poluição: vermelho, laranja, verde ou branco. Os projetos de energia eólica e solar são classificados como indústrias "brancas" e não necessitam de uma licença, uma vez que os impactos ambientais adversos a longo prazo são considerados de menor relevância. Permissões específicas, contudo, podem ser necessárias se o projeto estiver localizado em áreas sob a Lei da Conservação Florestal, em limites de um santuário de vida selvagem ou em parques nacionais (HOFFMANN et al. 2019). 


\section{JUSTIFICATIVA}

Tendo em vista a atual situação mundial, em que se espera diminuir cada vez mais as formas de obtenção de energia provenientes de fontes não renováveis e impactantes ao meio ambiente, é essencial a promoção de energias de fontes que sejam renováveis no Brasil, de forma que estas fiquem inseridas na matriz de eletricidade do país. Além disso, apesar de grande parte do fornecimento de energia elétrica no país ser proveniente de recursos hídricos, até então abundantes no Brasil, em virtude da situação crítica em muitos períodos de seca em regiões do país, é necessário que se tenham outras alternativas renováveis de fontes energéticas. A energia fotovoltaica é uma destas pois, atrelado ao fato de que se tem uma grande abundância de dias ensolarados e propícios para a utilização dessa tecnologia, tem-se ainda outros benefícios, como a possibilidade de produção de energia no próprio local de consumo. E, para que se assegure a sustentabilidade da utilização desse tipo de fonte para geração de energia elétrica, é necessário que se tenha um licenciamento ambiental bem estruturado, de forma a solucionar ou reduzir os impactos negativos.

\section{OBJETIVO}

O presente trabalho tem o objetivo de analisar o processo de licenciamento ambiental de usinas solares fotovoltaicas no Brasil, de maneira crítica e de forma que se avalie o processo de aquisição das licenças.

\section{Objetivos Específicos}

- Analisar no âmbito estadual o licenciamento ambiental voltado para usinas solares fotovoltaicas no estado do Ceará;

- Identificar os obstáculos enfrentados para o processo de licenciamento ambiental em usinas solares e analisar quais dificuldades poderiam ser minimizadas e solucionadas;

- Fazer uma análise crítica dos problemas que são recorrentes no processo de licenciamento ambiental. 


\section{METODOLOGIA}

A metodologia utilizada para a realização desta dissertação iniciou-se com uma pesquisa bibliográfica seguida de uma revisão sistemática sobre o processo de licenciamento ambiental de uma usina solar fotovoltaica, em bases de artigos científicos, a fim de analisar como é o processo de licenciamento ambiental desse tipo de empreendimento, quais os seus potenciais impactos em cada etapa de aquisição de licenças, obstáculos a serem enfrentados no processo de licenciamento, como está atualmente a legislação ambiental para esse determinado tipo de fonte e leis nos âmbitos federal e estadual relacionadas a usinas fotovoltaicas.

Além disso, seguiu-se para a busca de informações acerca do panorama nacional da energia solar fotovoltaica, através de pesquisa na Agência Nacional de Energia Elétrica (ANEEL), para verificar o potencial já disponível desse tipo de fonte no Brasil, assim como usinas a serem instaladas num futuro próximo.

Para uma análise mais detalhada, o estado do Ceará foi selecionado como um estudo de caso, por já ter algumas usinas instaladas e por ter uma legislação estadual direcionada para esse tipo de fonte. Assim, realizou-se uma entrevista não estruturada com uma pessoa técnica que atua como advogada na área de licenciamento ambiental no Ceará, para avaliar suas perspectivas e o processo de forma mais detalhada. Dessa forma, é possível analisar no âmbito estadual o licenciamento ambiental voltado para usinas solares fotovoltaicas no estado.

Com isso, é possível analisar os impactos envolvidos de cada etapa da aquisição das licenças prévia, de instalação e de operação, o complexo normativo que regula as questões ambientais legais existentes no país para esse tipo de empreendimento e os demais aspectos legais relacionados, com uma revisão narrativa. Ainda, é possível identificar os obstáculos enfrentados para o processo de licenciamento ambiental em usinas solares e analisar quais dificuldades poderiam ser minimizadas e solucionadas.

\section{ESTRUTURA DA DISSERTAÇÃO}

A dissertação está dividida em 6 capítulos, sendo o segundo relacionado à energia solar fotovoltaica no Brasil, comentando inicialmente um pouco do histórico do setor elétrico brasileiro. Adiante, é mostrado o panorama de energia solar fotovoltaica no Brasil, a influência 
da meteorologia nesse tipo de fonte e os incentivos que foram fornecidos para o avanço desse tipo de fonte de geração elétrica no Brasil.

O terceiro capítulo direciona-se ao direito no Brasil, sua hierarquia normativa e mais especificamente ao direito ambiental no país, tanto nos âmbitos federal como estadual.

Já o quarto capítulo foca no licenciamento ambiental, desde seu conceito, complexo normativo envolvido até os estudos e relatórios que são feitos. Ainda, são comentados os impactos ambientais que estão atrelados às usinas solares fotovoltaicas.

No quinto capítulo, é realizado um estudo de caso sobre empreendimentos de geração de energia elétrica solar fotovoltaica no estado do Ceará, comentando sobre o potencial de geração solar no Brasil, usinas solares em operação no estado, legislação ambiental no Ceará assim como resoluções normativas estaduais para licenciamento ambiental desse tipo de empreendimento. Ainda, é discorrido de maneira mais detalhada o processo de licenciamento de usinas solares fotovoltaicas no estado através de entrevista não estruturada.

Por fim, é feita uma análise dos desafios e problemas enfrentados, além de orientações e sugestões para possíveis soluções, a fim de consistir todas as informações relevantes que possam auxiliar no procedimento de licenciamento ambiental para esse tipo de fonte no Brasil. 


\section{ENERGIA SOLAR FOTOVOLTAICA NO BRASIL}

O setor elétrico no Brasil, antes dos anos 90, era operado majoritariamente por empresas estatais que apresentavam tarifas uniformes regionalmente. Através do Programa Nacional de Desestatização houve a privatização muitas empresas do setor, majoritariamente distribuidoras, além da criação da Agência Nacional de Energia Elétrica (ANEEL), para desenvolver um regime de regras e fiscalizar o setor, para seu bom funcionamento (FERNANDINO \& OLIVEIRA, 2010).

Criado no Governo de Fernando Henrique Cardoso pela lei 9.074, em 1995, o mercado livre de energia visava a livre concorrência e o estímulo à competitividade entre as empresas do setor, além de redução de custos com energia elétrica e incentivos ao desenvolvimento de novas fontes de geração de energia elétrica (CCEE, 2018).

Em 2000, a Lei ${ }^{\circ}$ 9.991, promulgada pelo Governo Federal, exigia que as empresas do setor direcionassem $1 \%$ da sua receita operacional líquida para desenvolvimento de pesquisas e projetos da área de tecnologia. Ainda, para as concessionárias, ocorreu um maior investimento para que estas desenvolvessem uma visão voltada para o longo prazo, para aumentar a competitividade, possibilitar estudos e pesquisas diversificadas e aumentar a interação com a população e com as universidades (FERNANDINO \& OLIVEIRA, 2010).

Os anos 90 estavam apresentando riscos de não suprimento de demanda energética, em função do esgotamento de capacidade de geração proveniente de fontes hidráulicas e do aumento de carga energética, provocada pela melhora na economia em função do Plano Real. Com isso surgiu então a necessidade de procurar outras fontes de energia. Com o Projeto de Reestruturação do Setor Elétrico Brasileiro (Projeto RE-SEB), houve então uma reforma e expansão no setor, para atrair capitais privados e aprimorar o mesmo. Desverticalizou-se assim o setor, separando os segmentos de geração, transmissão e distribuição de energia elétrica, sendo que estes últimos dois sob regulação do Estado (SALGADO \& MOTTA, 2005).

Com os riscos de não suprimento da demanda, sentiu-se a necessidade de um melhor acompanhamento e adequação do setor para evitar esse tipo de situação. Assim, foi criado o Operador Nacional do Sistema Elétrico (ONS), em 1998, e o Mercado Atacadista de Energia Elétrica (MAE), em 2002. Posteriormente, foi criado um órgão que iria ser responsável pelo 
planejamento do setor elétrico a longo prazo, a Empresa de Pesquisa Energética (EPE). Ainda, foi criada também a Câmera de Comercialização de Energia Elétrica (CCEE), responsável pela parte financeira e de mercado do setor, dando continuidade às tarefas exercidas pelo MAE (FERNANDINO \& OLIVEIRA, 2010).

O mercado de energia elétrica está dividido em dois ambientes: o de contratação regulada (ACR) e o de contratação livre (ACL). No ambiente regulado participam os agentes de geração e distribuição de energia elétrica e onde estão os consumidores cativos, que são os que compram energia através das concessionárias de distribuição às quais estão ligados. No ambiente livre participam os agentes de geração, comercialização, assim como os consumidores livres, que compram energia diretamente dos geradores ou de empresas comercializadoras, a partir de contratos bilaterais, sendo as condições destes acordadas entre ambas as partes (ABRACEEL, 2016).

O ambiente físico de energia é o mesmo para ambos os ambientes de contratação, mas no livre os consumidores podem escolher sua fonte de geração e negociar preço, prazo etc. $\mathrm{O}$ requisito para ser consumidor livre é de que a unidade consumidora deve conter uma demanda contratada a partir de $500 \mathrm{~kW}$, para adquirir energia gerada a partir de fontes renováveis, como pequenas centrais hidrelétricas, termelétricas a biomassa, eólica, solar, entre outras, ou igual ou acima de $3.000 \mathrm{~kW}$ para qualquer fonte de geração (ABRACEEL, 2016).

Outro benefício desse tipo de mercado é que a energia contratada pode ser convencional ou incentivada. Com o objetivo de estimular a expansão de geradores de fontes renováveis, como pequenas centrais hidrelétricas, de biomassa, eólica ou solar, o Governo Federal criou alguns benefícios para quem fizesse uso da energia incentivada. Para os mesmos serem mais competitivos, o comprador de energia proveniente dessas fontes recebe descontos na tarifa de uso do sistema de distribuição. A energia convencional é proveniente de outros tipos de geradores, como térmicas a gás, nucleares ou grandes hidrelétricas (ABRACEEL, 2016).

\subsection{Panorama Brasileiro de Energia Solar Fotovoltaica}

No Brasil, assim como em muitos outros países, vem se tornando crescente a procura por energia solar, em função da atual situação mundial de escassez de recursos, além do fato de ser 
uma energia renovável, não degradando de forma significativa o meio ambiente, já tão deteriorado pelo ser humano.

A disseminação dessa tecnologia surgiu com sistemas isolados, com o objetivo de fornecer eletricidade para locais distantes da rede de distribuição elétrica, sistemas esses que continuam a exercer sua função. Nos centros urbanos, o sistema fotovoltaico pode ser implantado em áreas já ocupadas, em telhados de residências, coberturas de prédios, entre outros exemplos, para então não ocupar outro espaço e reaproveitar o já existente. Um ótimo exemplo é a utilização desses sistemas em prédios públicos, que exercem a maior parte de suas atividades no período diurno, ou seja, coincidindo então com o período de produção de energia solar, reduzindo assim a necessidade por outras fontes de energia (ZILLES, 2012).

Como consequência de ser possível o aproveitamento de espaços já existentes para implantação de um sistema fotovoltaico, como mencionado anteriormente, a participação da energia solar fotovoltaica na geração distribuída de energia elétrica no Brasil é bastante significativa, com uma participação de cerca de $96,7 \%$, conforme é mostrado na tabela a seguir:

\section{Tabela 1 - Unidades Consumidoras com Geração Distribuída}

\begin{tabular}{|c|c|c|c|c|}
\hline Tipo & Quantidade & $\begin{array}{c}\text { Quantidade de Ucs que recebem } \\
\text { créditos }\end{array}$ & $\begin{array}{c}\text { Potência Instalada } \\
(\mathbf{k W})\end{array}$ & $\%$ \\
\hline CGH & 41 & 6.338 & $35.065,84$ & $0,88 \%$ \\
\hline EOL & 65 & 128 & $14.913,36$ & $0,37 \%$ \\
\hline UFV & 317.863 & 396.318 & $3.856 .702,57$ & $96,70 \%$ \\
\hline UTE & 265 & 4.741 & $81.819,65$ & $2,05 \%$ \\
\hline
\end{tabular}

Fonte: autoria própria com base na ANEEL - outubro de 2020. Sendo: CGH = Central Geradora Hidrelétrica; EOL = Eólica; UFV = Fotovoltaica; UTE $=$ Termelétrica.

A geração distribuída é contemplada de duas formas, geração off-grid e on-grid, sendo desconectadas da rede elétrica de distribuidora ou conectadas a rede elétrica (gerando crédito 
de energia com a distribuidora), respectivamente.

Já em relação à geração centralizada de energia elétrica, que contempla as usinas solares fotovoltaicas, há no Brasil 9925 empreendimentos em operação, totalizando 173.521.386,84 kW de potência instalada fiscalizada. Destes, 3.113.946,25 kW são de empreendimentos de geração solar fotovoltaica, o que corresponde a 1,79\% do total. Deste total de usinas, podem ser observadas suas localizações no Brasil pela Figura 1:

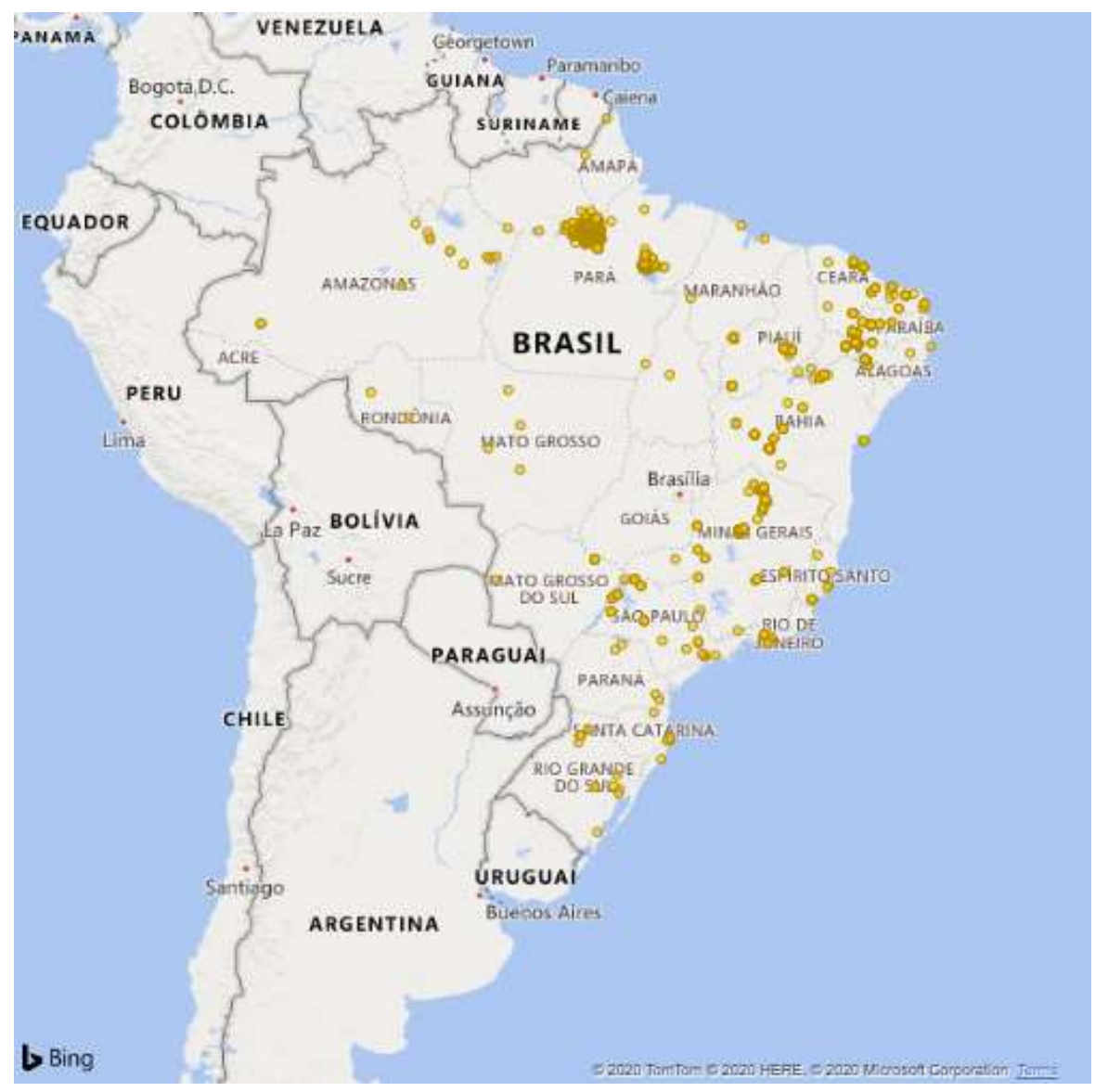

Figura 1 - Localização de empreendimentos de geração centralizada de energia solar fotovoltaica

Fonte: ANEEL, 2020.

Ainda em relação à geração centralizada, é esperado um incremento significativo até 2024, como visto pela Figura 2, o que irá contribuir para a evolução dessa fonte no país, totalizando assim 4,2 GW de potência instalada. Com isso, a geração fotovoltaica irá ter uma contribuição 
mais significativa na matriz de eletricidade brasileira.

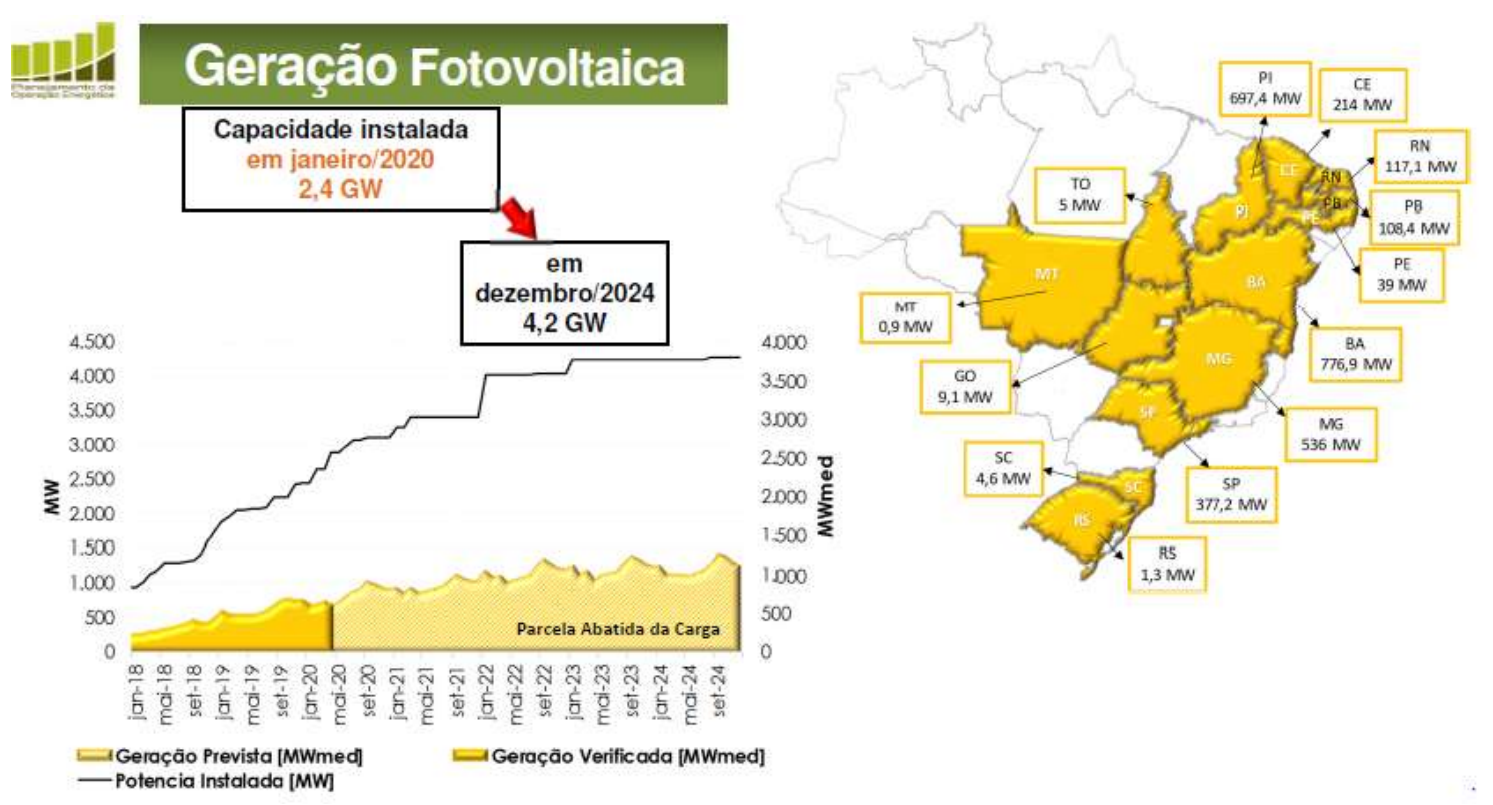

Figura 2 - Geração Fotovoltaica atual e prevista até 2024

Fonte: ONS - PEN 2020 - Condições Hidroenergéticas Futuras, julho de 2020

\subsection{Influência da Meteorologia na Geração de Energia Fotovoltaica no Brasil}

As informações acerca da meteorologia são fundamentais quando se planeja a implementação de uma usina solar, visto que a geração de energia vai depender da luz solar em abundância na superfície do local a serem colocados os módulos fotovoltaicos (PEREIRA, 2019).

No Brasil e no mundo já se tornou importante o aprimoramento de informações meteorológicas para controle e planejamento da inserção de sistemas fotovoltaicos, de forma que haja a expansão destes com base nas condições ambientais que favoreçam esses sistemas (LIMA, 2015).

De acordo com Lima (2015), o interesse por tais estudos relacionados ao clima e tempo estão intrinsicamente ligados à variabilidade do recurso energético solar. Segundo o autor, o resultado do processo é afetado por alterações como nebulosidade e concentrações de gases aerossóis causados por sistemas meteorológicos, afetando dessa forma a radiação solar na atmosfera. 
Ainda, segundo Pereira (2018), locais mais elevados são normalmente mais frios, ou seja, o relevo também possui influência sobre as condições meteorológicas. Além disso, os locais frios são mais susceptíveis a apresentarem formação de nebulosidade, em virtude da condensação de encostas.

Contudo, o Brasil apresenta em boa parte de sua extensão climas tropicais e subtropicais. Como o país possui uma proporção continental, abrange então áreas de baixas e altas latitudes, com diferentes índices de precipitação (VIANELLO \& ALVES, 2013).

A região que abrange a Amazônia possui precipitações entre médias e elevadas. As regiões Sudeste e Sul, segundo Pereira (2017), estão em uma área de transição entre os climas quentes de baixas latitudes, temperado de latitudes médias e subtropical.

Dessa forma, o Brasil apresenta um regime de chuvas bem significativo, como a ZCAS (Zona de Convergência do Atlântico Sul), que é caracterizada por uma banda de nebulosidade persistente e organizada com orientação noroeste-sudeste, que se estende desde a Amazônia até o oceano Atlântico, influenciando significativamente as chuvas nas regiões Centro-Oeste, Sudeste, extremo norte da região Sul e centro-sul das regiões Norte e Nordeste (PEREIRA, 2019).

A região Centro-Oeste apresenta um padrão semelhante à região Sudeste, com influência de ZCAS e da Alta da Bolívia (PEREIRA, 2017).

A região Nordeste possui áreas que apresentam características distintas, com a porção sul sofrendo mais influência de sistemas pré-frontais, sistemas frontais semi-estacionários, convecção local e brisas de mar. Ainda, pode ser observada a ZCIT (Zona de Convergência Intertropical) na costa leste da região Nordeste (PEREIRA 2019 apud MENEGHETTI 2009).

Já a região Norte, que apresenta muita influência da região Amazônica, também é afetada pela ZCIT e por sistemas frontais. A região tem uma atividade convectiva bastante presente ao longo do ano (PEREIRA, 2019).

Ainda, Lima (2015) afirma que existe uma variação na radiação solar incidente sobre a superfície em virtude dos aerossóis atmosféricos, sendo estes produzidos nas grandes cidades 
ou provenientes de queima de biomassa, podendo causar uma forte atenuação, principalmente direta, da incidência de radiação solar.

\subsection{Incentivos à Energia Solar Fotovoltaica no Brasil}

Como primeira iniciativa de âmbito nacional para incentivo da utilização da energia solar fotovoltaica tem-se o Programa de Desenvolvimento Energético de Estados e Municípios, ou PRODEEM, estabelecido em dezembro de 1994 pelo governo brasileiro, que instalou aproximadamente 9 mil sistemas fotovoltaicos em cinco fases de geração energética e uma de bombeamento de água. Esses sistemas tiveram suas instalações em 1996 mas efetivamente implantados em 2001 em todos os estados do país, principalmente nas regiões Norte e Nordeste (VARELLA et al.. 2008 apud GALDINO \& LIMA, 2002).

Em abril de 2002, oito anos depois, através da Lei $n^{\circ} 10.438$, revisada pela Lei $n^{\circ} 10.762$, de novembro de 2003, foi formado o Programa de Incentivo às Fontes Alternativas de Energia Elétrica (PROINFA), pelo Ministério de Minas e Energia - MME, programa que foi considerado o maior na época em território brasileiro em termos de incentivo a essas fontes (MME, 2006).

Entretanto, a energia solar fotovoltaica não foi incluída como uma das fontes incentivadas pelo Programa, em função de seu alto custo, o que a tornava apenas atrativa em localidades mais isoladas, por conta do baixo consumo local e dificuldade de acesso às redes elétricas, além da dispersão dos usuários (PORTO, 2007).

Em 2007 foi impulsionado um incentivo para fabricação de módulos fotovoltaicos nacionais, através de um acordo técnico-científico para a implementação do Centro Brasileiro para o Desenvolvimento de Energia Solar Fotovoltaica - CB-SOLAR, assinado pelo Ministério da Ciência e Tecnologia - MCT, sendo resultado de uma parceria entre os três âmbitos de governo: federal, estadual e municipal (PUCRS, 2007). O mesmo foi implantado no Núcleo Tecnológico de Energia Solar - NT-Solar, pertencente à Pontifícia Universidade Católica do Rio Grande do Sul - PUCRS (CRESESB, 2007).

No ano de 2011, através do edital 013/2011 ocorreu o evento de Projetos de Pesquisa e Desenvolvimento (P\&D) Estratégico - Arranjos Técnicos e Comerciais para Inserção da 
Geração Solar Fotovoltaica na Matriz Energética Brasileira, envolvendo 62 instituições, 584 pesquisadores e 96 empresas, no qual dos 18 projetos que foram candidatados, 17 foram aprovados, o que corresponde a uma capacidade de 24,578 MWp (EPE, 2014). Tal programa alavancou um grande avanço para a inserção dessa fonte no país.

O Programa Luz para Todos (LPT) é uma iniciativa que promove a instalação de módulos fotovoltaicos para comunidades em locais remotos, sem acesso à energia elétrica. A revisão dos planos de universalização para distribuição de energia elétrica em áreas rurais foi estimulada pelas condições estabelecidas pela Resolução Normativa n 488/2012 da ANEEL. Foi criada também, em 5 de junho de 2012, a Resolução Normativa $n^{\circ}$ 493, da ANEEL, que visava estabelecer procedimentos e as condições de fornecimento de energia elétrica por meio de microssistema isolado de geração e distribuição de energia elétrica - MIGDI ou sistema individual de geração de energia elétrica com fonte intermitente - SIGFI (SILVA, 2015).

Para o desenvolvimento da micro $(\leq 100 \mathrm{~kW})$ e minigeração $(\leq 1 \mathrm{MW})$ distribuídas de energia elétrica foi desenvolvida a resolução normativa da ANEEL $n^{\circ} 482$, de 2012, que permitiu o direito dos consumidores brasileiros em gerarem sua própria energia elétrica a partir de fontes renováveis. Além disso, o excedente energético poderia ser vendido para as distribuidoras locais, gerando assim créditos para futuras cobranças ou para outros imóveis pertencentes ao mesmo proprietário. Caso não houvesse excedente, o consumidor apenas pagaria a diferença entre o injetado e consumido na rede (ANEEL, 2017).

Para fins de melhoramento do planejamento, foi revisada em 2015 essa resolução a partir da Resolução Normativa $n^{\circ}$ 687/2015 da ANEEL, a fim de reduzir custos e tempo para a conexão da microgeração e minigeração, expandir o público alvo, tornar compatível o Sistema de Compensação de Energia Elétrica com as Condições Gerais de fornecimento (Resolução Normativa $n^{\circ} 414 / 2010$ ) e aprimorar as informações na fatura. Dentre essas mudanças estão: aumento do tempo de viabilidade de créditos de excedente energético, de 36 para 60 meses, podendo abater o consumo de outras unidades consumidoras sob o nome do mesmo proprietário; possibilidade de instalação de geração distribuída em condomínios, sendo a energia repartida da maneira desejada pelos próprios consumidores; possibilidade de geração compartilhada por interessados unidos em um consórcio ou cooperativa, para redução de suas faturas; e simplificação no processo de conexão da micro ou minigeração distribuída à rede distribuidora, reduzindo o prazo, de 82 para 34 dias, para a distribuidora conectar usinas de até 
$75 \mathrm{~kW}$ e pelo fato de deixar disponível um formulário padrão para solicitação de acesso pelo consumidor (ANEEL, 2017).

Posteriormente, a resolução 482 da ANEEL foi revisada novamente pela resolução 786 em outubro de 2017, a fim de alterar o limite de potência para minigeração maior que $78 \mathrm{~kW}$ e menor ou igual a $5 \mathrm{MW}$ para todas as fontes. Esta resolução vedou o enquadramento como geração distribuída (GD) das centrais que já tiveram registro, concessão, permissão ou autorização ou tenham entrado em operação comercial ou, ainda, contabilizado no âmbito da CCEE.

Para o ano de 2020 há uma nova resolução da REN 482 a entrar em vigor. Segundo a ANEEL, é necessária uma avaliação e revisão frequente por este ser um setor recente, de forma que as reais necessidades do mercado de energia solar sejam refletidas pela regulação.

A resolução começou a ser discutida por motivação dos distribuidores de energia, que alegam que o sistema que está em vigor impede a remuneração adequada da rede de distribuição. Tal afirmação se deve ao fato de que o excedente gerado em uma unidade consumidora de micro ou minigeração injetado na rede abate integralmente o mesmo montante de energia consumida. Assim sendo, a tarifa injetada na rede por esses consumidores é valorada pela tarifa de energia elétrica estabelecida por esses consumidores (ANEEL, 2019).

Portanto, a nova revisão propõe que a energia injetada na rede por esse consumidor não seja recuperada de maneira integral em datas futuras, de forma que a cada $1 \mathrm{~W}$ injetado este receba o crédito proporcional a $0,8 \mathrm{~W}$ por exemplo. Muitos agentes alegam, no entanto, que tal medida irá prejudicar o avanço da energia solar, impedindo sua consolidação no mercado.

Ainda como vantagem para a utilização desse tipo de fonte, há descontos nas Tarifas de Uso dos Sistemas de Transmissão (TUST) e de Distribuição (TUSD). Para empreendimentos em que sua potência injetada nos sistemas de distribuição e de transmissão seja equivalente ou menor do que $30.000 \mathrm{~kW}$, e que entraram em operação até 31 de dezembro de 2017, o desconto sobre essas tarifas é de $80 \%$. Esse desconto passa a ser de $50 \%$ a partir do $11^{\circ}$ ano de operação da usina solar e se o empreendimento tiver início a partir de $1^{\circ}$ de janeiro de 2018. Além disso, há a possibilidade de venda direta, sem intermediação de distribuidoras, de geradores de fontes alternativas como a solar, cuja potência injetada seja inferior a $50.000 \mathrm{~kW}$, para consumidores 
especiais que detenham uma carga entre $500 \mathrm{~kW}$ e $3.000 \mathrm{~kW}$, que acabam por se beneficiar com o desconto na TUSD (ANEEL, 2017).

Em relação aos materiais utilizados nos painéis, há um programa que auxilia na redução de custos de semicondutores e produção de células de filme fino, o Programa de Apoio ao Desenvolvimento Tecnológico da Indústria de Semicondutores (PADIS), de forma que torne mais acessível a utilização de tais materiais (ROSA \& GASPARIN, 2016).

Ainda como incentivo, há redução de imposto de renda para projetos prioritários que têm sua implementação nas áreas da Superintendência do Desenvolvimento do Nordeste (SUDENE), da Superintendência do Desenvolvimento da Amazônia (SUDAM) e da Superintendência do Desenvolvimento do Centro-Oeste (SUDECO), sendo que o setor de energia elétrica é um dos considerados mais importantes. Vale destacar que as regiões da Sudam e da Sudene são regiões em que há grande incidência de irradiação solar propícia para a utilização de módulos fotovoltaicos (SILVA, 2015).

O Banco Nacional de Desenvolvimento Econômico e Social (BNDES) também estimulou a evolução da fonte solar, apoiando Projetos de Eficiência Energética (PROESCO), cedendo financiamento a projetos que contribuam de alguma forma para a eficiência energética, substituindo as fontes térmicas oriundas da utilização de combustíveis fósseis por fontes renováveis (ROSA \& GASPARIN, 2016).

Ainda, promove condições diferenciadas a essas fontes, com baixas taxas de juros e permitindo um prazo de 20 anos de amortização. Demais condições benéficas foram concedidas à fonte solar pelo Leilão de Energia de Reserva (LER) de 2014, estimulando inclusive a produção nacional de equipamentos (ROSA \& GASPARIN, 2016). Anteriormente à esse leilão ocorreram dois leilões em 2013 em que houve a participação da fonte solar, porém nenhum projeto contratado, já que a fotovoltaica estava competindo com projetos de outras fontes com custo mais baixo, portanto mais competitivos. Entretanto foi um marco importante, uma vez que sinalizou aos empreendedores e investidores a intenção de se inserir a fonte solar na matriz de eletricidade brasileira.

No LER de 2014, em que só havia projetos de energia solar, 400 estavam cadastrados, totalizando uma potência de $10.790 \mathrm{MWp}$. Desses, 31 foram contratados, totalizando uma 
potência de 1048,2 MWp, chegando a preço médio de R\$215,12/MWh. Tudo isso envolveu um investimento de $\mathrm{R} \$ 4,1$ bilhões (EPE, 2014).

Após um ano ocorreu o $1^{\circ}$ Leilão de Reserva de 2015, com um total de 30 empreendimentos de energia fotovoltaica, totalizando uma capacidade de $1043 \mathrm{MWp}$, sendo que preço médio ficou em torno de R \$301,79/MWh e o investimento cerca de R \$ 4,3 bilhões (EPE, 2015). No mesmo ano aconteceu o $2^{\mathrm{a}} \mathrm{LER}$, que contou com 33 projetos, totalizando $1115 \mathrm{MWp}$ e um preço médio de R\$297,75/MWh (EPE, 2015).

Em 2017, o leilão A-4 terminou com o domínio da fonte solar no certame, viabilizando 20 projetos, com menor preço por usina cotado a R\$143/MWh e o maior a R\$ 146/MWh, totalizando 574 MW (CANAL ENERGIA, 2017). Já em 2018, novamente a maior vendedora foi a fonte solar, viabilizando 29 usinas, com 806,66 MW em nova capacidade e 228,5 MWm. Isso mostra como a redução dos preços da fonte solar acabou aumentando sua atratividade, aumentando assim o número dos projetos viabilizados em leilões (ABSOLAR, 2018).

A Caixa Econômica Federal também forneceu incentivos para promover o desenvolvimento de empreendimentos que se interessassem pela utilização de energia solar. Através do Construcard, que oferecia financiamento para equipamentos diversos, inclusive de energia solar fotovoltaica e aerogeradores. A pessoa física tem de 2 a 6 meses para comprar todo o material necessário, pagando apenas os juros referentes aos valores utilizados. Posteriormente, tem até 238 meses para retornar o valor do investimento a uma taxa de variação de $1,4 \%$ mais $2,33 \%$ de taxa de referência, não podendo ultrapassar 240 meses a soma entre a utilização e o prazo de amortização (Caixa Econômica Federal, 2015).

Outro incentivo foi o Fundo Clima, vinculado ao Ministério de Minas e Energia, que oferecia financiamento para pesquisa e projetos que influenciassem na redução de impactos voltados ao aquecimento global, o que engloba projetos com a temática da energia solar (ROSA \& GASPARIN, 2016).

Ainda na área de pesquisa há o programa Inova Energia, em que são oferecidos recursos para aprimoramento de problemas ou ineficácias relacionadas aos equipamentos e tecnologia relacionados ao sistema fotovoltaico ou termossolar, além das demais fontes de energia renovável (SILVA, 2015). 
Em 2014, no dia 8 de agosto em Campinas, o CTI Renato Archer inaugurou o Laboratório de Energia Fotovoltaica Richard Louis Anderson, a partir de recursos do Ministério da Ciência, Tecnologia e Inovação, via FINEP (Financiadora de Estudos e Projetos). Com o objetivo de incentivar esse tipo de tecnologia para microgeração em edifícios integrados, o laboratório, que é o primeiro dentro de uma instituição federal voltado para tal finalidade, conta com pesquisas diversas no ramo, desenvolvendo módulos customizados (ROSA \& GASPARIN, 2016). 


\section{DIREITO NO BRASIL VOLTADO AO LICENCIAMENTO AMBIENTAL}

Existem direitos individuais e coletivos, que também podem ser chamados de trans-individuais. O direito coletivo pode se dividir em direito difuso, aquele que está presente em toda a sociedade sem distinção de grupos ou individualidades; coletivo, no qual se determina a existência de uma coletividade dentro da sociedade; individual homogêneo, no qual passa a existir um grupo determinado após a ocorrência de um fato jurídico; e indisponível, que abrange a evolução da predominância dos direitos sociais sobre os individuais. O direito ambiental é essencialmente classificado como difuso, mas dependendo das características do dano ambiental pode ser tratado como coletivo (ARAUJO, 2002).

No direito ambiental há princípios, que servem como norteadores, dando sustentação às leis e normas. É interessante serem mencionados tais princípios para que se compreenda a relação da responsabilidade com possíveis danos que determinada atividade possa exercer sobre o meio ambiente. Com base às suas classificações, tem-se:

- o princípio da precaução: o qual esclarece se deve agir ou não antes que o dano se concretize, ou seja, se não tiver certeza científica dos danos e como repará-los, não se deve executar tal atividade relacionada ao meio ambiente (MACHADO, 2005);

- o princípio da prevenção: muitas vezes confundido com o princípio da precaução, sua aplicação ocorre quando já existe conhecimento de um provável dano ambiental e suas consequências, mesmo que parciais, fornecendo sustentação ao estudo do impacto ambiental e ao relatório do meio ambiente, ou seja, é este princípio que obriga o licenciamento ambiental, dando também base ao poder de polícia, uma vez que trata da capacidade da fiscalização e aplicação de sanções pelo órgão público (FIORILLO, 2005);

- o princípio da responsabilidade: por este princípio, o poluidor responde por suas ações ou omissões, neste caso as sanções ocorrem nas esferas civil, penal e/ou administrativa, tendo por base a responsabilidade civil objetiva (MACHADO, 2005);

- o princípio do usuário pagador: este princípio retrata que os bens ambientais são de todos e, portanto, pode a coletividade estabelecer valores à eles, retrata que como os recursos não são abundantes devem ser utilizados de maneira razoável (MILARÉ, 2014); 
- o princípio do poluidor pagador: este princípio obriga o pagamento pela poluição causada através de indenização e/ou recuperação, sendo regido pela responsabilidade civil objetiva, mas não deve ser confundido com autorização para poluir (MACHADO, 2005);

- o princípio da educação ambiental: efetiva a prevenção e deve ser aplicado em todos os níveis de ensino, inclusive na comunidade, é um princípio que é parte integrante do gerenciamento ambiental (ARAUJO, 2002);

- o princípio da participação ambiental: este princípio elenca que a sociedade deve participar no processo de tomada de decisões em questão ambientais, dando substância ao licenciamento ambiental quando este realiza audiências públicas (MILARÉ, 2014);

- o princípio da informação ambiental: faz parte do princípio da participação e consiste no direito de ser informado, significa o acesso público aos dados e informações ambientais (MILARÉ, 2014);

- o princípio do desenvolvimento sustentável: tem por base que todos têm direito ao ambiente ecologicamente equilibrado e estabelece uma relação de equilíbrio entre a preservação do meio ambiente e o desenvolvimento econômico e social (ARAUJO, 2002).

\subsection{Hierarquia Normativa}

Em todos os ramos do direto existe uma hierarquização normativa a se seguir, não podendo uma norma inferior contrariar uma superior, invalidando a mesma. É necessário seguir a hierarquia da seguinte maneira:

\section{Constituição Federal}

2. Leis complementares

3. Leis Ordinárias

4. Medidas Provisórias

5. Atos Normativos (Regulamentos, Decretos, Portarias, Resoluções e Deliberações)

A Constituição Federal de 1988 está no topo do sistema legal, sendo a mais importante das normas, e serve como fundamento das demais regulamentações. Nela, estão inseridos todos os 
princípios básicos da nação. O Art. 225 da CF/88 é considerado fundamental no direcionamento da criação e aplicação da legislação ambiental brasileira, uma vez que se refere à preservação ambiental e ao direito de todos ao meio ambiente ecologicamente equilibrado, bem de uso comum do povo e essencial à qualidade de vida. Além do Art. 225 deve-se mencionar também o Art. 170 da CF/88, que trata do desenvolvimento sustentável. Ambos os artigos são base da proteção ambiental.

As Leis Complementares são complementares à $\mathrm{CF} / 88$, cujas finalidades são de detalhamento e esclarecimentos da Constituição. As leis Ordinárias podem abordar qualquer assunto que não exija Lei Complementar. Inclusive, uma grande parte do Direito Ambiental é constituído de Leis Ordinárias (federais, estaduais e municipais), como a Política Nacional do Meio Ambiental, a Lei Ordinária Federal no 6.938/81.

As Medidas Provisórias estão sob comando do Presidente da República, possuem a mesma importância das Leis Ordinárias e têm um perfil de urgência e relevância a serem cumpridos para sua edição.

Já os Atos Normativos apresentam força semelhante às leis, embora não obtenham posição de destaque na hierarquia, e precisam estar alinhados com a estrutura normativa. Estes têm efeitos legais que regulamentam questões ambientais em forma de Decretos, Resoluções, Portarias e Instruções (REIS, 2015).

\subsection{O Direito Ambiental no Brasil}

O direito ambiental no Brasil é relativamente recente. Anteriormente ao seu início, as questões ambientais eram resolvidas pelo código civil. Havia preocupação pontual, cujos objetivos eram de conservação e não de preservação, portanto era um período marcado pela exploração do mesmo (SIRVINSKAS, 2018).

Com a criação da Lei da Política Nacional do Meio Ambiente (1981), a preocupação passou a ser a proteção de maneira integral do meio ambiente, por meio de um sistema ecológico integrado, ou seja, a proteção de partes a partir de um todo, de modo a harmonizar o desenvolvimento econômico e social com a proteção do meio ambiente, promovendo o uso racional dos recursos naturais. Esta lei foi uma norma ambiental muito importante no país, uma vez que 
definiu conceitos básicos como poluição, degradação e meio ambiente, entre outros, além de desenvolver diretrizes e instrumentos e da criação da teoria da responsabilidade (REIS, 2015).

Ainda, descreveu o SISNAMA (Sistema Nacional de Meio Ambiente), que congrega órgãos e entidades de âmbitos federal, estadual e municipal, visando a proteção e qualidade do meio ambiente, sendo estruturados da seguinte maneira: Órgão Superior do Meio Ambiente (CMSAConselho Superior do Meio Ambiente), assessorando o Presidente da República nas diretrizes governamentais e formulação da política nacional; o Conselho Nacional do Meio Ambiente (CONAMA), órgão consultivo e deliberativo, estudando e propondo ao Conselho do Governo normas e padrões compatíveis com o meio ambiente ecologicamente equilibrado; Ministério do Meio Ambiente (MMA), órgão central que planeja, comanda, coordena e supervisiona a implementação da política nacional e das diretrizes direcionadas para o meio ambiente; o Instituto Brasileiro do Meio Ambiente e dos Recursos Naturais Renováveis (IBAMA), órgão executor que tem poder de polícia ambiental, onde atua no licenciamento ambiental, fiscalizando e assegurando o desenvolvimento sustentável; os órgãos seccionais, entidades estaduais que têm responsabilidade por executar projetos além do controle e fiscalização de atividades com potencial de degradação ambiental; e os órgãos locais, que são entidades municipais cujas responsabilidades estão atreladas à fiscalização e controle em suas respectivas jurisdições (REIS, 2015).

Nesse período posterior à lei n. 6938/81, da Política Nacional do Meio Ambiente, podem ser citadas algumas normas: a Lei n. 7347/85, que dispõe sobre a Ação Civil Pública; a Constituição Federal de 1988; a Lei n. 8171/91, que aborda a política agrícola; a Lei n. 9605/98, que aborda sanções administrativas e penais acerca de atividades nocivas ao meio ambiente; a Lei n. 9985/2000, sobre as Unidades de Conservação; a Lei n. 10.257/2001, que aborda o Estatuto da cidade; a Lei 11.445/2007, sobre a Política Nacional de Saneamento Básico; a Lei n. 12.305/2010, que aborda a Política Nacional dos Resíduos Sólidos (PNRS); e a lei n. 12.651/2012, que aborda o novo Código Florestal (SIRVINSKAS, 2018).

Com a criação da $\mathrm{CF} / 88$, as questões ambientais foram trazidas de maneira mais gerais e centralizadas. Ao longo dela, tem-se diversos trechos que discorrem sobre os deveres do governo e da sociedade para o meio ambiente, mencionando repartições de competências entre os âmbitos federal, estadual e municipal para defesa do meio ambiente. Introduziu, pela primeira vez na história do país, um capítulo específico sobre meio ambiente, considerando-o como um bem comum do povo e essencial à sadia qualidade de vida, impondo ao Poder Público 
e à coletividade o dever de preservá-lo para as gerações presentes e futuras. A lei complementar n. 140/11 também menciona tal aspecto, levando em consideração a localização do empreendimento, fixando normas entre as entidades dos âmbitos federal, estadual e municipal (BRASIL, 1988).

\subsubsection{Legislação ambiental no âmbito estadual}

O processo de legislação ambiental no âmbito estadual é complementar à federal, não podendo haver discordância entre estes, de forma que o estadual pode vir a surgir como um complemento ao que foi estabelecido pela União, quando necessário. Além disso, os estados devem respeitar o que foi estabelecido pelo CONAMA. De acordo com o Art. 23 e o Art. 18 da CF/88 a União, os estados, o Distrito Federal e os municípios são autônomos, contanto que seja respeitada a hierarquia dos âmbitos que estão acima. Para regulamentação de peculiaridades do estado, ele possui competência para isso, através das Comissões Organizadoras, respeitando o Regulamento Nacional.

Em relação à estrutura do SISNAMA, a autonomia dos estados estará garantida pelos órgãos seccionais que, conforme o Decreto n ${ }^{\circ}$ 99274/90, são responsáveis pela fiscalização de projetos potencialmente poluidores e/ou degradantes e pela execução de projetos, por exemplo o COSEMA (Conselho Estadual de Meio Ambiente) e GAMA(Gerência Adjunta do Meio Ambiente) (REIS, 2015). 


\section{LICENCIAMENTO AMBIENTAL NO BRASIL}

O licenciamento ambiental é o instrumento estatal mais importante na defesa do meio ambiente, assegurando o desenvolvimento, mas de forma sustentável. É um processo administrativo no qual o órgão ambiental concede as licenças para a localização, instalação, ampliação, modificação e operação de empreendimentos/atividades que façam uso de recursos ambientais e são considerados efetiva ou potencialmente poluidores ou que posam causar algum dano ambiental (MMA, 1997).

A partir deste instrumento, buscam-se medidas preventivas, de controle e mitigatórias nos empreendimentos/atividades, de forma a assegurar o desenvolvimento sustentável do mesmo, ou seja, não de apenas proteção ao meio ambiente, mas também garantir a atratividade do país a investimentos, com o mínimo de impacto ambiental negativo (MME, 2013).

A lei n. 6938/81 definiu que essas atividades (efetiva ou potencialmente poluidoras) deviam ser licenciadas, como está em seu artigo 10:

Art. 10. A construção, instalação, ampliação e funcionamento de estabelecimentos e atividades utilizadores de recursos ambientais, efetiva ou potencialmente poluidores ou capazes, sob qualquer forma, de causar degradação ambiental dependerão de prévio licenciamento ambiental (BRASIL, 1981).

Para o processo do licenciamento, o primeiro passo para seu início é a definição do órgão ambiental que será responsável por emitir a licença, que irá verificar a necessidade da mesma e quais os processos que irão dar continuidade para a obtenção de cada uma delas.

As obrigações de cada órgão federativo, sendo este o IBAMA, os Órgãos Estaduais do Meio Ambiente (OEMAs) ou Órgãos Municipais do Meio Ambienta (OMMAs), são definidas pelo complexo normativo brasileiro. Para o processo de licenciamento, deve-se definir qual destes é responsável por emitir a licença.

A função de proteger e preservar o meio ambiente é uma tarefa que diz respeito à todos, conforme é estipulado pela $\mathrm{CF} / 88$, que determina também que é uma obrigação dos estados, podendo o IBAMA atuar em sua ausência ou omissão, de acordo com a lei 6.938/81, que concedeu competência para licenciar obras de potencial impacto negativo no âmbito nacional ou 
regional (impacto sobre dois ou mais estados). Além disso, possuem função supletiva definida pela lei $\mathrm{n}^{\mathrm{o}}$ 6.938/81 de o órgão ser solicitado nas seguintes situações: por mandato judicial; por decisão do CONAMA; por solicitação do órgão ambiental competente; por descumprimento dos prazos estipulados na Resolução CONAMA n ${ }^{\circ}$ 237/97, referente aos artigos 14 e 15, pelo órgão ambiental encarregado; e por diploma legal específico (ARAUJO, 2002).

Já os órgãos ambientais municipais, cabe a estes atuar em licenciamento ambiental de impacto local, após consultar órgãos da União, dos estados e do Distrito Federal. O licenciamento ambiental não é feito por mais de um órgão, podendo haver apenas consulta dos demais.

Durante o processo de licenciamento, é possível que sejam solicitados estudos complementares acerca de impactos ambientais, além de impactos na saúde da população próxima ao empreendimento ou atividade e demais impactos socioeconômicos. Os responsáveis por providenciar esses estudos são os solicitantes da licença e devem ser realizados por profissionais qualificados. Os estudos possuem o objetivo de prever possíveis impactos causados pela implantação do empreendimento, elaborar forma de mitigá-los e propor medidas compensatórias.

Na Resolução CONAMA nº 237/97 já há uma lista de atividades consideradas potencialmente poluidoras em seu anexo I, que necessitam então de licenciamento ambiental. Já os empreendimentos que não demonstram acarretar grandes impactos podem exigir outros estudos a serem feitos, mais simples, que pode ser mostrado pelo artigo $3^{\circ}$ da Resolução 237/97:

Art. $3^{\circ}$ - A licença ambiental para empreendimentos e atividades consideradas efetiva ou potencialmente causadoras de significativa degradação do meio dependerá de prévio estudo de impacto ambiental e respectivo relatório de impacto sobre o meio ambiente (EIA/RIMA), ao qual dar-se-á publicidade, garantida a realização de audiências públicas, quando couber, de acordo com a regulamentação.

Parágrafo único. O órgão ambiental competente, verificando que a atividade ou empreendimento não é potencialmente causador de significativa degradação do meio ambiente, definirá os estudos ambientais pertinentes ao respectivo processo de licenciamento. (BRASIL, 1997) 
A Resolução CONAMA nº 001 de 1986 em conjunto com a Resolução CONAMA n ${ }^{\circ}$ 237/1997 dispõe sobre critérios básicos e diretrizes gerais para a avaliação do impacto ambiental (AIA). A AIA tem como objetivo identificar as consequências futuras que um determinado empreendimento pode gerar. Os procedimentos de investigação são diferentes, pois não se trata de antecipar uma situação futura, mas de tentar medir o dano ambiental e, ocasionalmente, de valorar economicamente as perdas (passivos ambientais) (OLIVEIRA, 2012).

Para empreendimentos de baixo potencial ambiental negativo o licenciamento é simplificado (SILIS - Sistema de Licenciamento Simplificado), com um respectivo relatório ambiental simplificado (RAS). Em empreendimentos de significativo impacto ambiental, deverá ser feito um Estudo de Impacto Ambiental (EIA) e correspondente Relatório de Impacto ao Meio Ambiente (RIMA). Como antecedente à esses estudos, é apresentado um Relatório Ambiental Prévio (RAP).

O EIA e seu respectivo RIMA são instrumentos essenciais na AIA. Através destes, é possível garantir que haja uma manutenção da sustentabilidade dos empreendimentos a serem licenciados. Para isso, conforme é mostrado nas Figuras 3 e 4 a seguir, é feito um diagnóstico ambiental da área que irá ser afetada pelo projeto (meios físico, biológico e socioeconômico), uma análise dos impactos ambientais e suas alternativas tecnológicas e locacionais, caracterização da qualidade ambiental futura da área de influência após a implementação do projeto, definição de medidas mitigadoras dos impactos negativos e assim a elaboração de um programa de acompanhamento e monitoramento.

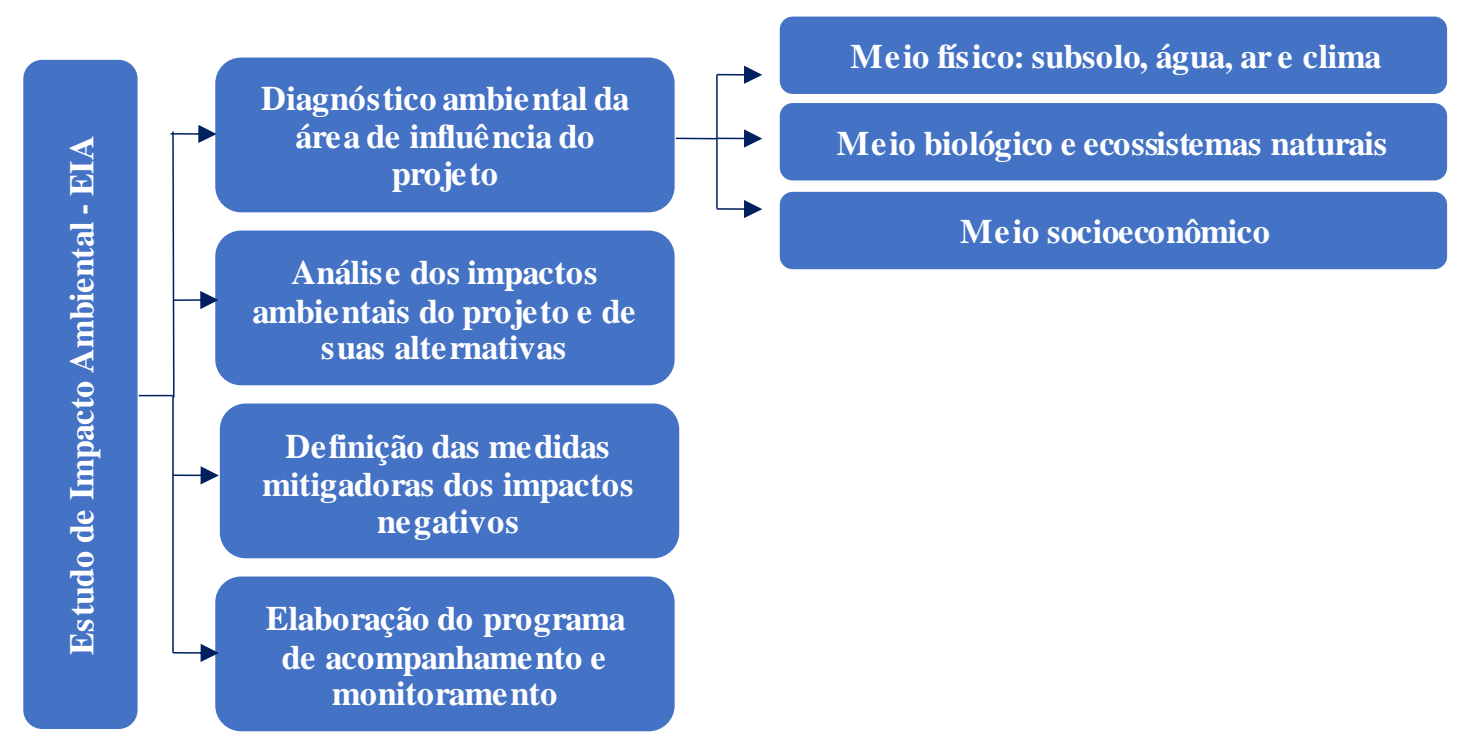

Figura 3 - Conteúdo mínimo do Estudo de Impacto Ambiental (EIA)

Fonte: Reis, 2012-adaptado 


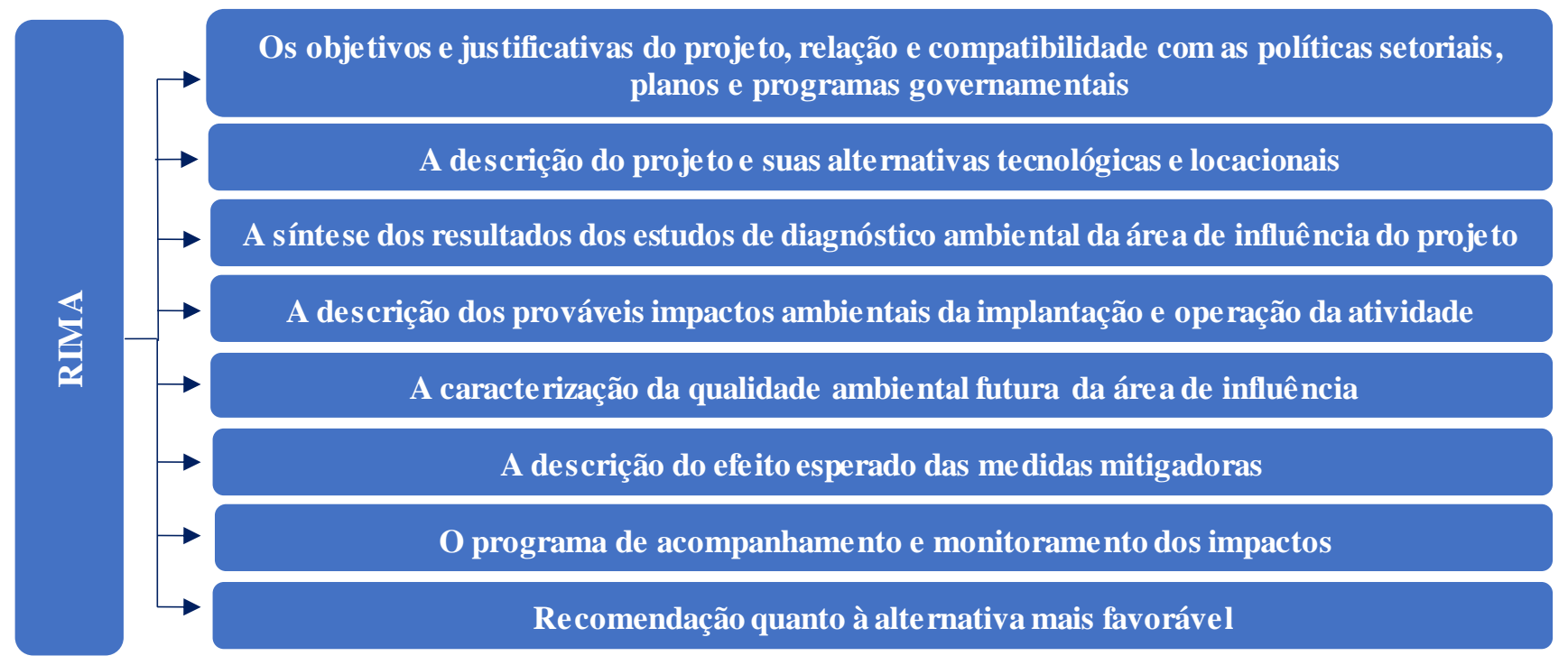

Figura 4 - Conteúdo mínimo do Relatório de Impacto ao Meio Ambiente (RIMA)

Fonte: Reis, 2012-adaptado

Para o processo de licenciamento ambiental (exemplificado pela Figura 5) ser efetivo é necessário que se obtenham as três licenças, uma para o planejamento do empreendimento, a licença prévia, uma para a construção, a licença de instalação, e outra para a operação, a licença de operação. Essas licenças são definidas pelo Decreto no 99.274/97 (ARAUJO, 2002):

- Licença Prévia (LP): tem por base viabilizar o empreendimento. Para isso, inicia o processo de licenciamento pela aprovação do projeto com o órgão ambiental. Para a emissão, deve-se atender os requisitos básicos com relação às fases de localização, instalação e operação. Com estudos de impacto ambiental, identificação e programas de mitigação de impactos negativos, além de eventual maximização dos positivos, tem-se então a verificação da viabilidade do empreendimento. Nessa fase que são feitos os estudos de impacto ambiental, com apresentação dos respectivos relatórios.

- Licença de Instalação (LI): tem como principal objetivo autorizar a instalação do empreendimento. Para sua obtenção, analisa a licença anterior (LP), verificando se as ações mitigatórias e demais condicionantes para a sustentabilidade do projeto estão sendo seguidas, 
que compõem o Plano de Controle Ambiental (PCA), como medidas de compensação ambiental etc.

- Licença de Operação (LO): tem como função a autorização da operação do empreendimento, atendendo dessa forma o que foi estabelecido nas licenças anteriores. Para fiscalização do que foi proferido nas licenças anteriores, é feita uma vistoria pelo órgão que está responsável pelo licenciamento (OLIVEIRA, 2012).

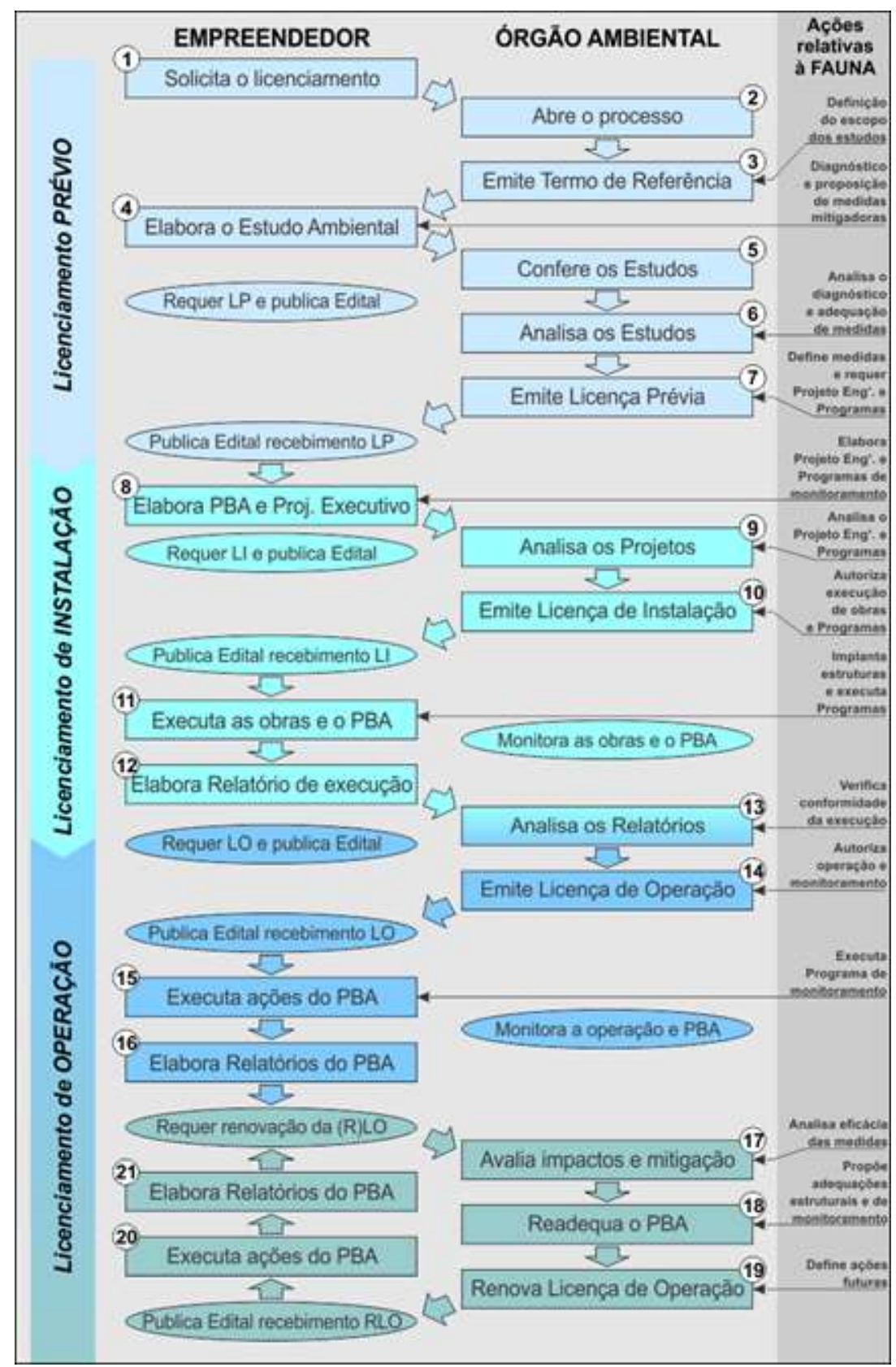

Figura 5 - Processo de Licenciamento Ambiental

Fonte: Conecte, 2012 
Os prazos de validade das licenças determinados pela Resolução CONAMA 237/97 são:

- Licença Prévia: máximo de 5 anos

- Licença de Instalação: máximo de 6 anos

- Licença de Operação: mínimo e 4 anos e máximo de 10 anos

Os prazos são limites e o órgão ambiental fica responsável por estabelecer a validade de cada licença em relação às condições dos pedidos. Na Licença Prévia, deve-se considerar o cronograma estabelecido para elaboração de todos os componentes relacionados ao empreendimento ou atividade. Na Licença de Instalação, é necessário levar em conta o cronograma de instalação do empreendimento ou atividade. Na Licença de Operação, a consideração está relacionada aos planos de controle ambiental.

A análise dos pedidos das três licenças também tem prazos máximos, assim como é descrito no artigo 14 da resolução CONAMA 237/97:

Art. 14 - O órgão ambiental competente poderá estabelecer prazos de análise diferenciados para cada modalidade de licença (LP, LI e LO), em função das peculiaridades da atividade ou empreendimento, bem como para a formulação de exigências complementares, desde que observado o prazo máximo de 6 (seis) meses a contar do ato de protocolar o requerimento até seu deferimento ou indeferimento, ressalvados os casos em que houver EIA/RIMA e/ou audiência pública, quando o prazo será de até 12 (doze) meses. (BRASIL, 1997)

Conforme mencionado anteriormente, para empreendimentos com baixo potencial poluidor, o processo de licenciamento ambiental pode ser feito de maneira simplificada, conforme estabelecido na Resolução CONAMA n²279 de 27 de junho de 2001:

Art. $1^{\circ}$ - Os procedimentos e prazos estabelecidos nesta Resolução, 
aplicam-se, em qualquer nível de competência, ao licenciamento ambiental simplificado de empreendimentos elétricos com pequeno potencial de impacto ambiental, aí incluídos:

I - Usinas hidrelétricas e sistemas associados;

II - Usinas termelétricas e sistemas associados;

III - Sistemas de transmissão de energia elétrica (linhas de transmissão e subestações).

IV - Usinas Eólicas e outras fontes alternativas de energia (BRASIL, 2001).

Seguindo o processo simplificado, o licenciamento ambiental das usinas solares fotovoltaicas se inicia com a identificação do órgão competente para emitir as licenças. Se o empreendimento se enquadrar no caso do processo simplificado, o responsável pelo empreendimento, assim como o responsável técnico pelo licenciamento, serão encarregados de elaborar uma declaração de que o empreendimento de fato se enquadra para o processo simplificado, e irão também providenciar a solicitação da licença prévia, que então será acompanhada pelo Relatório Ambiental Simplificado (RAS), conforme define a Resolução CONAMA n²79 de 2001:

Art. 2o Para os fins desta Resolução, são adotadas as seguintes definições:

I - Relatório Ambiental Simplificado RAS: os estudos relativos aos aspectos ambientais relacionados à localização, instalação, operação e ampliação de uma atividade ou empreendimento, apresentados como subsídio para a concessão da licença prévia requerida, que conterá, dentre outras, as informações relativas ao diagnóstico ambiental da região de inserção do empreendimento, sua caracterização, a identificação dos impactos ambientais e das medidas de controle, de mitigação e de compensação. (BRASIL, 2001). 
Ainda, é necessário que seja providenciado o registro na Agência Nacional de Energia Elétrica (ANEEL), além de demais considerações por demais órgãos que estejam envolvidos. Além disso, dependendo do local do empreendimento, pode ser necessária uma outorga de direito dos recursos hídricos ou da reserva de disponibilidade hídrica.

Feito todo o processo mencionado, o órgão ao qual foi solicitada a licença prévia irá definir se o empreendimento se enquadra para o processo simplificado. Se caso o empreendimento não se enquadrar, irá seguir então o processo não simplificado, e se for enquadrado irá seguir com o Relatório Ambiental Simplificado (RAS - Figura 6). O RAS irá fazer também a descrição do projeto, o diagnóstico e prognóstico ambiental e definir medidas mitigadoras e compensatórias, porém com um processo mais simplificado, cuja vantagem é o fato de ser muito mais rápido. $\mathrm{O}$ prazo para a emissão das licenças é de, no máximo, sessenta dias, contados a partir da data de protocolização do requerimento das licenças.

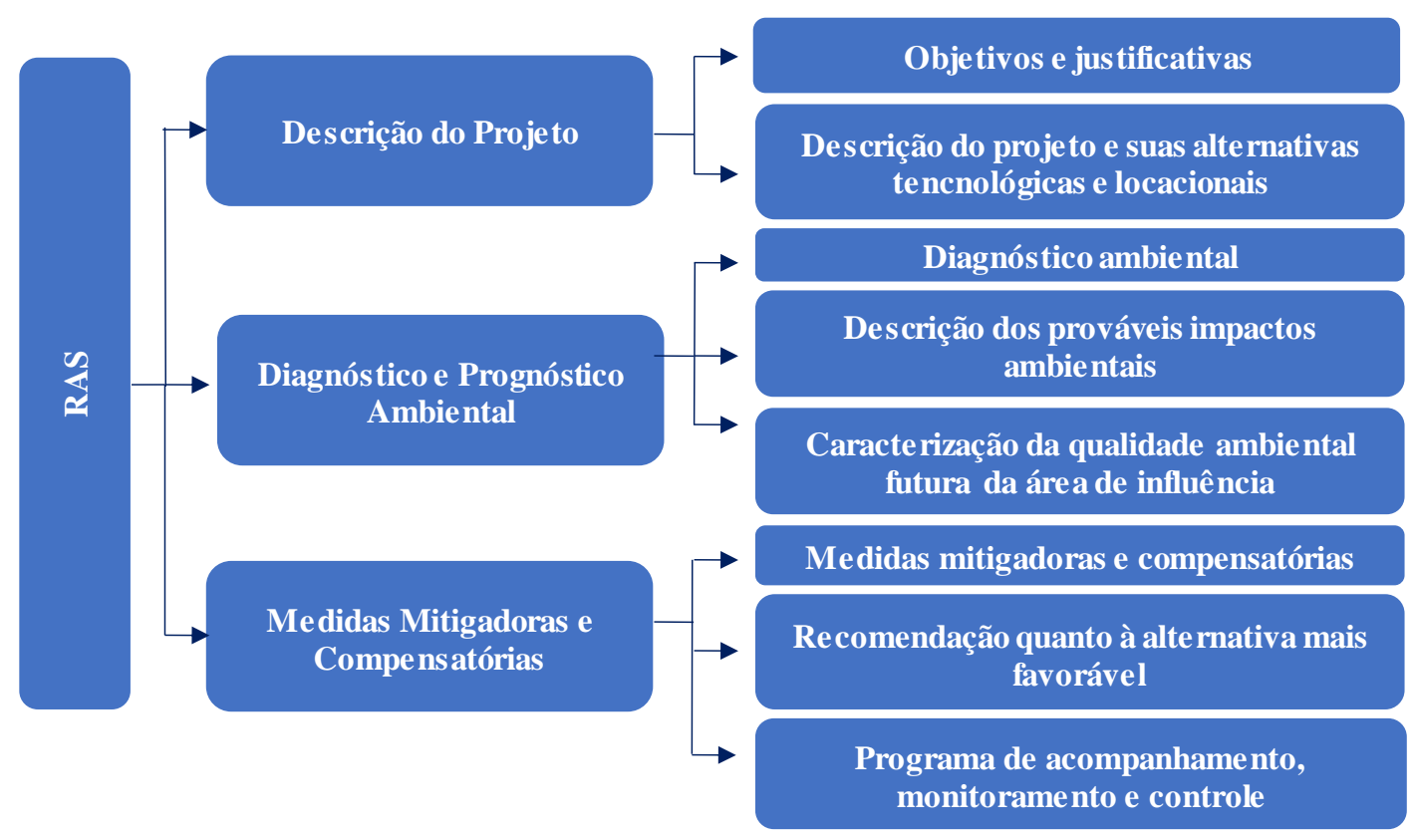

\section{Figura 6 - Conteúdo do RAS}

Fonte: Reis, 2012

Entretanto, o prazo pode ser estendido se o órgão responsável julgar necessidade de maiores esclarecimentos. Pode ocorrer, por exemplo, o requerimento de estudos complementares (mediante justificativas técnicas). Dessa forma, o prazo será suspenso até a conclusão dos novos estudos, podendo esse período se estender até sessenta dias. Caso esse prazo não seja suficiente 
para a conclusão dos estudos, o empreendedor poderá prorrogar sua entrega e, caso não seja efetiva, o processo será cancelado.

Com a licença de instalação, o empreendedor tem a obrigação de se atentar ao planejamento e cronograma apresentado na licença prévia, caso o prazo não seja cumprido, a licença de instalação perderá sua eficácia. Com uma justificativa, o empreendedor pode pedir a prorrogação do prazo.

Durante o processo de implantação dos sistemas, é obrigação do investidor providenciar a Licença de Operação, que só será emitida caso haja o cumprimento das condicionantes solicitadas na Licença de Instalação pelo órgão ambiental responsável. O prazo desta é de também até sessenta dias após requerimento. Para a verificação de que todos as condicionantes tenham sido cumpridas, pode-se solicitar testes para a verificação do atendimento.

Caso haja a não comunicação de alguma atividade ou fato que não tenha sido identificado, a responsabilidade para fazê-lo é do empreendedor, mesmo estando a cargo do órgão ambiental responsável. Dessa forma, poderá ser punido caso haja uma omissão comprovada, podendo haver mudanças no processo de licenciamento se houver identificação de que houve negligência pela não comunicação por parte do empreendedor.

\subsection{Roteiro para Elaboração de Estudos Ambientais}

De acordo com os Artigos $5^{\circ}$ e $6^{\circ}$ da Resolução CONAMA n ${ }^{\circ} 1$ de 23 de janeiro de 1986, um Estudo de Impacto Ambiental, além de atender à legislação, deve atender algumas diretrizes, tais como:

Avaliação de alternativas tecnológicas e de localização do projeto, analisando-as em confronto com a hipótese de não execução

Definição dos limites da área que pode ser direta ou indiretamente afetada por impactos decorrentes do projeto; 
> Verificação da compatibilidade do projeto com programas governamentais que estejam propostos e em implantação na área de influência do empreendimento;

Elaboração de diagnóstico ambiental da área de influência do empreendimento, considerando os meios físico, biótico e socioeconômico;

Identificação e análise dos potenciais impactos ambientais provenientes das fases do licenciamento: planejamento, implantação e operação da atividade;

Definição das medidas mitigadoras dos impactos negativos, avaliando a eficiência de cada uma delas; e

Elaboração de programa de acompanhamento e monitoramento das medidas propostas.

Além disso, conforme a CONAMA 01/86, o órgão ambiental fica encarregado de solicitar demais instruções adicionais que julgar pertinentes.

Como muitos estados não possuem sua própria regulamentação, no Apêndice A apresentase uma proposta de instruções relativas ao conteúdo de um estudo de impacto ambiental, elaborado com base na Decisão de Diretoria no 217/2014/I, de 06 de agosto da CETESB.

\section{2 Compensação Ambiental}

Caso haja impactos negativos sobre a área afetada pelo empreendimento ou atividade que não possam ser mitigados, a Lei Federal no 9.985/2000 (Sistema Nacional de Unidades de Conservação - SNUC), em seu artigo $n^{\circ} 36$, institui um mecanismo financeiro de forma que se pague para compensar os danos causados. Esta lei também se refere à Compensação Ambiental, sendo que sua publicação revigorou implicitamente a Resolução CONAMA n 02/1996 quando em seu art. 36 afirma:

Art. 36. Nos casos de licenciamento ambiental de empreendimentos de significativo impacto ambiental, assim considerado pelo órgão ambien- 
tal competente, com fundamento em estudo de impacto ambiental e respectivo relatório - EIA/RIMA, o empreendedor é obrigado a apoiar a implantação e manutenção de unidade de conservação do Grupo de Proteção Integral, de acordo com o disposto neste artigo e no regulamento desta Lei.(Regulamento)

$\S 1^{\circ} \mathrm{O}$ montante de recursos a ser destinado pelo empreendedor para esta finalidade não pode ser inferior a meio por cento dos custos totais previstos para a implantação do empreendimento, sendo o percentual fixado pelo órgão ambiental licenciador, de acordo com o grau de impacto ambiental causado pelo empreendimento. (Vide ADIN n ${ }^{\circ} 3.378-$ 6 , de 2008)

$\S 2^{\circ}$ Ao órgão ambiental licenciador compete definir as unidades de conservação a serem beneficiadas, considerando as propostas apresentadas no EIA/RIMA e ouvido o empreendedor, podendo inclusive ser contemplada a criação de novas unidades de conservação. [...] (BRASIL, Lei no 9985, 2000)

Como visto pela Resolução CONAMA no 02/1996, após a apresentação dos estudos ambientais, no caso o EIA/RIMA para projetos que causem tamanhos impactos negativos sobre o meio ambiente, o empreendedor é responsável por compensar pela degradação da área e a população local atingida, destinando recursos (no mínimo meio por cento dos custos totais previstos para a implantação do empreendimento) à criação de UCs (Unidades de Conservação) de Proteção Integral (áreas com permissão apenas do uso indireto de seus recursos) ou manutenção destas.

A Lei $n^{\circ}$ 9.985/2000 em 2002 começou a ser regulamentada pelo Decreto Federal $n^{\circ}$ 4.340/2002, no qual encontra-se o Capítulo VIII que é específico para a "compensação por significativo impacto ambiental". Neste capítulo estão descritos em quatro artigos os detalhes sobre o procedimento de compensação:

Art. 31. Para os fins de fixação da compensação ambiental de que trata o art. 36 da Lei no 9.985, de 2000, o órgão ambiental licenciador esta- 
belecerá o grau de impacto a partir de estudo prévio de impacto ambiental e respectivo relatório - EIA/RIMA realizados quando do processo de licenciamento ambiental, sendo considerados os impactos negativos e não mitigáveis aos recursos ambientais. (Alterado pelo Decreto Federal $n^{\circ}$ 6.848, de 2009) Parágrafo único. Os percentuais serão fixados, gradualmente, a partir de meio por cento dos custos totais previstos para a implantação do empreendimento, considerando-se a amplitude dos impactos gerados, conforme estabelecido no caput. (Alterado pelo Decreto Federal $n^{\circ} 6.848$, de 2009)

Art. 32. Será instituída no âmbito dos órgãos licenciadores câmaras de compensação ambiental, compostas por representantes do órgão, com a finalidade de analisar e propor a aplicação da compensação ambiental, para a aprovação da autoridade competente, de acordo com os estudos ambientais realizados e percentuais definidos. (Alterado pelo Decreto Federal $n^{\circ} 6.848$, de 2009)

Art. 33. A aplicação dos recursos da compensação ambiental de que trata o art. 36 da Lei no 9.985, de 2000, nas unidades de conservação, existentes ou a serem criadas, deve obedecer à seguinte ordem de prioridade:

I - regularização fundiária e demarcação das terras;

II - elaboração, revisão ou implantação de plano de manejo;

III - aquisição de bens e serviços necessários à implantação, gestão, monitoramento e proteção da unidade, compreendendo sua área de amortecimento;

IV - desenvolvimento de estudos necessários à criação de nova unidade de conservação; e

$\mathrm{V}$ - desenvolvimento de pesquisas necessárias para o manejo da unidade de conservação e área de amortecimento. 
Parágrafo único. Nos casos de Reserva Particular do Patrimônio Natural, Monumento Natural, Refúgio de Vida Silvestre, Área de Relevante Interesse Ecológico e Área de Proteção Ambiental, quando a posse e o domínio não sejam do Poder Público, os recursos da compensação somente poderão ser aplicados para custear as seguintes atividades:

I - elaboração do Plano de Manejo ou nas atividades de proteção da unidade;

II - realização das pesquisas necessárias para o manejo da unidade, sendo vedada a aquisição de bens e equipamentos permanentes;

III - implantação de programas de educação ambiental; e

IV - financiamento de estudos de viabilidade econômica para uso sustentável dos recursos naturais da unidade afetada.

Art. 34. Os empreendimentos implantados antes da edição deste Decreto e em operação sem as respectivas licenças ambientais deverão requerer, no prazo de doze meses a partir da publicação deste Decreto, a regularização junto ao órgão ambiental competente mediante licença de operação corretiva ou retificadora. (Brasil, Decreto 4.340, 2002)

Posteriormente foi editado o Decreto Federal no 6.848/2009, alterando os arts. 31 e 32 do Decreto Federal n ${ }^{\circ}$ 4.340/2002 e acrescentando os artigos 31-A e 31- B.

Art. $1^{\circ}$. Os arts. 31 e 32 do Decreto no 4.340, de 22 de agosto de 2002, passam a vigorar com a seguinte redação:

“Art. 31. Para os fins de fixação da compensação ambiental de que trata o art. 36 da Lei no 9.985, de 2000, o Instituto Brasileiro do Meio Ambiente e dos Recursos Naturais Renováveis - IBAMA estabelecerá o grau de impacto a partir de estudo prévio de impacto ambiental e respectivo relatório - EIA/RIMA, ocasião em que considerará, exclusivamente, os impactos ambientais negativos sobre o meio ambiente. 
$\S 1^{\circ} \mathrm{O}$ impacto causado será levado em conta apenas uma vez no cálculo.

$\S 2^{\circ} \mathrm{O}$ cálculo deverá conter os indicadores do impacto gerado pelo empreendimento e das características do ambiente a ser impactado.

$\S 3^{\circ}$ Não serão incluídos no cálculo da compensação ambiental os investimentos referentes aos planos, projetos e programas exigidos no procedimento de licenciamento ambiental para mitigação de impactos, bem como os encargos e custos incidentes sobre o financiamento do empreendimento, inclusive os relativos às garantias, e os custos com apólices e prêmios de seguros pessoais e reais.

$\S 4^{\circ}$ A compensação ambiental poderá incidir sobre cada trecho, naqueles empreendimentos em que for emitida a licença de instalação por trecho” (NR) “

Art. 32. Será instituída câmara de compensação ambiental no âmbito do Ministério do Meio Ambiente, com a finalidade de:

I - estabelecer prioridades e diretrizes para aplicação da compensação ambiental;

II - avaliar e auditar, periodicamente, a metodologia e os procedimentos de cálculo da compensação ambiental, de acordo com estudos ambientais realizados e percentuais definidos;

III - propor diretrizes necessárias para agilizar a regularização fundiária das unidades de conservação; e

IV - estabelecer diretrizes para elaboração e implantação dos planos de manejo das unidades de conservação" (NR)

Art. $2^{\circ}$. O Decreto no 4.340, de 2002, passa a vigorar acrescido dos seguintes artigos: 
“Art. 31-A. O Valor da Compensação Ambiental - CA será calculado pelo produto do Grau de Impacto - GI com o Valor de Referência - VR, de acordo com a fórmula a seguir:

$\mathrm{CA}=\mathrm{VR} \times \mathrm{GI}$, onde:

$\mathrm{CA}=$ Valor da Compensação Ambiental;

$\mathrm{VR}=$ somatório dos investimentos necessários para implantação do empreendimento, não incluídos os investimentos referentes aos planos, projetos e programas exigidos no procedimento de licenciamento ambiental para mitigação de impactos causados pelo empreendimento, bem como os encargos e custos incidentes sobre o financiamento do empreendimento, inclusive os relativos às garantias, e os custos com apólices e prêmios de seguros pessoais e reais; e

$\mathrm{GI}=$ Grau de Impacto nos ecossistemas, podendo atingir valores de $0 \mathrm{a}$ $0,5 \%$.

$\S 1^{\circ} \mathrm{O}$ GI referido neste artigo será obtido conforme o disposto no Anexo deste Decreto.

$\S 2^{\circ} \mathrm{O}$ EIA/RIMA deverá conter as informações necessárias ao cálculo do GI.

$\S 3^{\circ}$ As informações necessárias ao calculo do VR deverão ser apresentadas pelo empreendedor ao órgão licenciador antes da emissão da licença de instalação.

$\S 4^{\circ}$ Nos casos em que a compensação ambiental incidir sobre cada trecho do empreendimento, o VR será calculado com base nos investimentos que causam impactos ambientais, relativos ao trecho." (NR)

“Art. 31-B. Caberá ao IBAMA realizar o cálculo da compensação ambiental de acordo com as informações a que se refere o art. 31-A. 
$\S 1^{\circ} \mathrm{Da}$ decisão do cálculo da compensação ambiental caberá recurso no prazo de dez dias, conforme regulamentação a ser definida pelo órgão licenciador.

$\S 2^{\circ} \mathrm{O}$ recurso será dirigido à autoridade que proferiu a decisão, a qual, se não a reconsiderar no prazo de cinco dias, o encaminhará à autoridade superior.

$\S 3^{\circ} \mathrm{O}$ órgão licenciador deverá julgar o recurso no prazo de até trinta dias, salvo prorrogação por igual período expressamente motivada.

$\S 4^{\circ}$ Fixado em caráter final o valor da compensação, o IBAMA definirá sua destinação, ouvido o Instituto Chico Mendes de Conservação da Biodiversidade - Instituto Chico Mendes e observado o $§ 20$ do art. 36 da Lei no 9.985, de 2000” (NR) (BRASIL, Decreto nº 6.848, 2009).

Com isso, foi estabelecido um critério para o cálculo de forma a mensurar o valor da Compensação Ambiental, sendo este o produto do grau de impacto (que pode variar entre 0 a 0,5\%, conforme Anexo do próprio Decreto acima descrito) com o valor de referência, que corresponde aos custos necessários para que se instale o empreendimento, com exceção dos citados no $\S 3^{\circ}$ do art. 31 do Decreto (Revista Argumentum apud DOMINGUES, CARNEIRO, 2010).

\subsection{Os Impactos Ambientais Atrelados às Usinas Solares Fotovoltaicas}

As usinas solares fotovoltaicas apresentam impactos em suas fases de planejamento, instalação e operação. No início do processo, período anterior à instalação do projeto, não são observados impactos consideráveis ao meio ambiente.

As fases seguintes, de instalação e operação, já apresentam impactos mais significativos. Para cada uma leva-se em consideração as medidas mitigadoras capazes de solucionar ou reduzir os impactos adversos que possam ser decorrentes dos processos.

Para avaliar os potenciais impactos ambientais, são listados os principais e as fases nos quais são decorrentes, de acordo com a verificação da interferência com meio. Posteriormente, 
são aplicadas atribuições de valor para cada impacto, dessa forma informando então quais são mais significativos, propondo a essas medidas de mitigação e definindo planos de controle ambiental. Para que estes impactos sejam classificados são considerados os seguintes atributos:

- Natureza: Positivo ou Negativo;

- Área de Abrangência: com relação às áreas de influência: ADA (Área Diretamente Afetada), AID (Área de Influência Direta), ou AII (Área de Influência Indireta);

- Duração do impacto: curta, cíclica, longa;

- Magnitude: pequena, média, grande;

- Importância: pequena, média, grande;

- Reversibilidade (capacidade de retornar ao estado natural): Irreversível, parcialmente reversível, reversível

Alguns dos impactos observados de usinas solares fotovoltaicos são descritos na tabela 2 a seguir, assim como quais meios são afetados (F - físico; $\mathrm{S}$ - social; B - biótico) por esses.

Tabela 2- Principais aspectos e impactos ambientais relacionados às usinas fotovoltaicas (UFV) 


\begin{tabular}{|c|c|c|c|}
\hline Fases & Aspectos ambientais das UFV & Impactos ambientais em potencial & Meio \\
\hline \multirow{20}{*}{ Implantação } & Terraplanagem e movimentação do solo & $\begin{array}{l}\text { Erosão do solo pela alteração da topografia e } \\
\text { exposição do solo }\end{array}$ & $\mathrm{F}$ \\
\hline & $\begin{array}{c}\text { Construção de vias de acesso (não } \\
\text { pavimentadas) }\end{array}$ & Assoreamento de cursos hídricos & $\mathrm{F}$ \\
\hline & $\begin{array}{l}\text { Montagem das estruturas metálicas de } \\
\text { sustentação dos módulos }\end{array}$ & Geração de resíduos da construção civil & $\mathrm{F}$ \\
\hline & $\begin{array}{c}\text { Conexão dos painéis, dos inversores e das } \\
\text { estruturas de suporte, que utiliza solda e } \\
\text { chumbo }\end{array}$ & \multirow[t]{3}{*}{ Possível contaminação do solo } & $\mathrm{F}$ \\
\hline & Instalação dos módulos & & $\mathrm{F}$ \\
\hline & Geração de resíduos de construção civil & & $\mathrm{F}$ \\
\hline & \multirow{3}{*}{ Área ocupada pela UFV } & $\begin{array}{c}\text { Impacto visual (Comprometimento da } \\
\text { paisagem) }\end{array}$ & $\mathrm{S}$ \\
\hline & & Alteração do uso do solo natural & $\mathrm{F}$ \\
\hline & & $\begin{array}{l}\text { Remoção e realocação de familias ou } \\
\text { comunidades }\end{array}$ & $\mathrm{S}$ \\
\hline & \multirow{4}{*}{ Supressão de vegetação } & Perda da cobertura vegetal original & $\mathrm{B}$ \\
\hline & & $\begin{array}{l}\text { Redução do habitát natural de espécies vegetais } \\
\text { e animais }\end{array}$ & $\mathrm{B}$ \\
\hline & & Afugentamento da fauna & $\mathrm{B}$ \\
\hline & & Riscos de acidentes com animais & $\mathrm{B}$ \\
\hline & $\begin{array}{c}\text { Aumento do tráfego de veículos leves e } \\
\text { pesados no entorno e interior da área de } \\
\text { implantação }\end{array}$ & $\begin{array}{c}\text { Redução na abundância populacional por meio } \\
\text { do atropelamento de fauna }\end{array}$ & $\mathrm{B}$ \\
\hline & \multirow[b]{2}{*}{ Demanda por mão de obra } & Geração de empregos diretos e indiretos & $\mathrm{S}$ \\
\hline & & $\begin{array}{l}\text { Desenvolvimento da qualificação da população } \\
\text { do entorno }\end{array}$ & $\mathrm{S}$ \\
\hline & \multirow{4}{*}{ Aumento da atividade econômica } & Aumento da arrecadação de impostos & $\mathrm{S}$ \\
\hline & & $\begin{array}{l}\text { Aumento de demanda por serviços públicos } \\
\text { (saúde, educação, infraestrutura, moradia) }\end{array}$ & $\mathrm{S}$ \\
\hline & & Valorização imobiliária & $\mathrm{S}$ \\
\hline & & $\begin{array}{l}\text { Aumento do fluxo de veículos nas estradas } \\
\text { locais }\end{array}$ & $\mathrm{S}$ \\
\hline \multirow{12}{*}{ Operação } & \multirow{3}{*}{ Área ocupada pela UFV } & $\begin{array}{l}\text { Comprometimento da paisagem, ofuscamento } \\
\text { por reflexão da luz }\end{array}$ & $\mathrm{F} / \mathrm{S}$ \\
\hline & & $\begin{array}{l}\text { Restrição de ocupação no entorno da UFV, } \\
\text { para evitar sombreamento }\end{array}$ & $\mathrm{F}$ \\
\hline & & $\begin{array}{c}\text { Aumento da susceptibilidade à erosão do solo } \\
\text { pelo maior escoamento superficial }\end{array}$ & $\mathrm{F}$ \\
\hline & Consumo de água para limpeza dos módulos & $\begin{array}{c}\text { Aumento do volume de escoamento superficial } \\
\text { de água (requer construção de sistema de } \\
\text { drenagem e contenção da água da chuva) }\end{array}$ & $\mathrm{F}$ \\
\hline & Cercamento da área (segurança) & $\begin{array}{c}\text { Restrição à circulação de certas espécies } \\
\text { animais }\end{array}$ & $\mathrm{B}$ \\
\hline & Sombreamento do solo pelos painéis FV & $\begin{array}{c}\text { Alteração do microclima para a vegetação } \\
\text { rasteira e pequenos animais }\end{array}$ & $\mathrm{B}$ \\
\hline & Demanda por mão de obra & $\begin{array}{c}\text { Geração/supressão de empregos diretos e } \\
\text { indiretos }\end{array}$ & S \\
\hline & \multirow{2}{*}{ Aumento da atividade econômica } & Aumento da arrecadação de impostos & $\mathrm{S}$ \\
\hline & & Valorização imobiliária & $\mathrm{S}$ \\
\hline & \multirow{3}{*}{ Geração de energia renovável } & Melhoria na oferta de energia elétrica & $\mathrm{S}$ \\
\hline & & $\begin{array}{c}\text { Complementariedade com relação a outras } \\
\text { fontes de geração de energia elétrica (aumento } \\
\text { da confiabilidade do sistema de geração de } \\
\text { energia elétrica) }\end{array}$ & $\mathrm{S}$ \\
\hline & & Emissões de GEE evitadas & $\mathrm{F}$ \\
\hline \multirow{3}{*}{ Desativação } & $\begin{array}{c}\text { Geração de resíduos sólidos de construção civil } \\
\text { e eletrônicos }\end{array}$ & $\begin{array}{l}\text { Potencial de contaminação do solo e ambiente } \\
\text { com metais pesados (chumbo, cromo, comp. } \\
\text { bromados) }\end{array}$ & $\mathrm{F}$ \\
\hline & \multirow[t]{2}{*}{ Desmobilização da UFV } & $\begin{array}{c}\text { Comprometimento paisagístico e degradação } \\
\text { ambiental }\end{array}$ & $\mathrm{S}$ \\
\hline & & Supressão de postos de trabalho & $\mathrm{S}$ \\
\hline
\end{tabular}


Fonte: Perazzoli et al. (2020)

Na etapa de montagem e complexação da estrutura dos painéis, são observados impactos advindos da conexão dos painéis, inversores e estruturas de suporte, cujos perigos estão relacionados aos industriais, envolvendo alumínio, aço e concreto.

Ainda, frequentemente faz-se a utilização de chumbo para a interligação dos circuitos eletrônicos e fiação, material também presente em pastas de impressão e revestimento de tiras de cobre.

Com relação aos impactos que não envolvem diretamente os painéis, o principal deles é a ocupação do solo. Para a inserção dos painéis, é necessária a supressão da vegetação da área na qual serão instalados, como consequência também exercendo impacto negativo sobre o meio biótico ali presente. Além disso, a terraplanagem, que é uma técnica construtiva que visa aplainar e aterrar um terreno, causa a erosão e salinização do solo pela alteração da topografia e exposição dele.

A área ocupada pela usina fotovoltaica não se restringe apenas à área ocupada pelos módulos fotovoltaicos inseridos. Além de ser necessário um espaço entre eles, para evitar assim sombreamento, é preciso também caminhos para manutenção. Todos esses impactos causam alterações na região (REIS, 2015).

Pode-se citar também outros impactos ambientais negativos relevantes, como o aumento da susceptibilidade à erosão do solo pelo maior escoamento superficial, alteração do microclima para a vegetação rasteira e pequenos animais, entre outros.

$\mathrm{Na}$ fase de desativação da usina também são esperados impactos ambientais relacionados à geração de resíduos sólidos de construção civil e eletrônicos, podendo causar contaminação do solo e ambiente com metais pesados provenientes desses materiais (como chumbo etc). 


\section{ESTUDO DE CASO: EMPREENDIMENTOS DE GERAÇÃO DE ENERGIA ELÉTRICA SOLAR FOTOVOLTAICA NO ESTADO DO CEARÁ}

Para fins comparativos e análise mais direcionada do processo de licenciamento ambiental para usinas solares fotovoltaicas, é feito um estudo de caso no estado do Ceará, uma vez que, além de ser uma região de muita incidência solar propícia para esse tipo de empreendimento, o estado recentemente avançou nessa questão ao estruturar a forma como deve ser feito o processo de licenciamento ambiental para esse tipo de fonte.

\subsection{Potencial de geração solar no Brasil}

O Atlas Brasileiro de Energia Solar (Figuras 7 e 8), que contou com a contribuição científica do Instituto Nacional de Ciência e Tecnologia para Mudanças Climáticas (INCT-MC), através de processos CNPq e FAPESP, o qual apoiou a fase de pesquisa, consolidação e de sua montagem final, avaliou o potencial de geração de energia elétrica a partir da fonte solar, utilizando 17 anos de dados satelitais e implementados vários avanços nas parametrizações do modelo de transferência radiativa BRASIL-SR.

O Atlas é resultado do trabalho cooperativo entre o INPE (Instituto Nacional de Pesquisas Espaciais) e pesquisadores de várias instituições no Brasil: a Universidade Federal de São Paulo (UNIFESP), a Universidade Federal de Santa Catarina (UFSC), a Universidade Tecnológica Federal do Paraná (UTFPR) e o Instituto Federal de Santa Catarina (IFSC). 


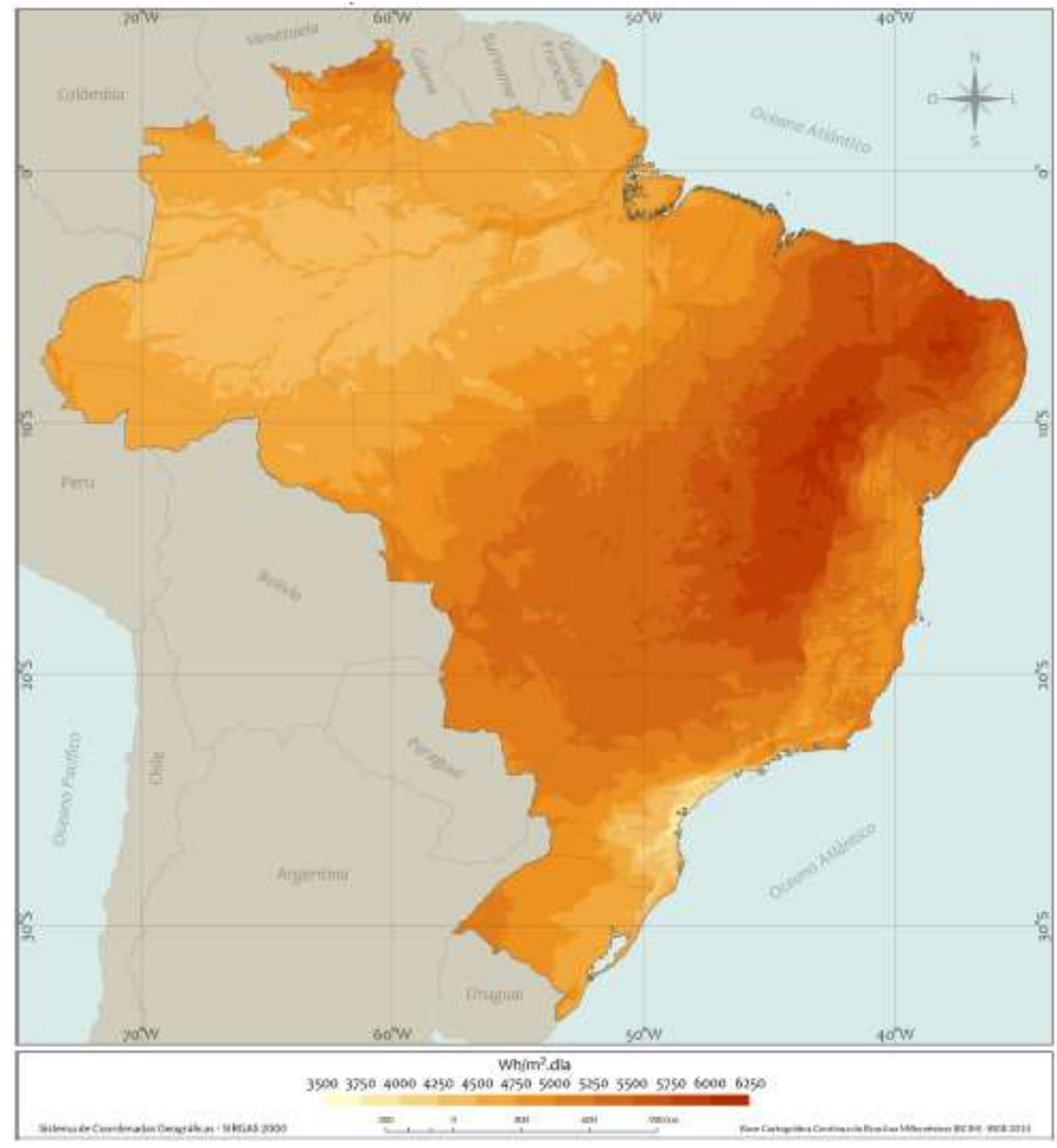

Figura 7 - Total diário da irradiação no plano inclinado na latitude - média anual Fonte: (O ATLAS BRASILEIRO DE ENERGIA SOLAR, 2017).

Como pode ser observado, o maior potencial está no Cinturão Solar, faixa que abrange desde o Nordeste até o Pantanal. Embora os estados do Nordeste tenham alta incidência solar, não estão em uma região com muitas opções de conexão com a rede nacional de distribuição de energia elétrica, o que pode inviabilizar os projetos, uma vez que torna mais cara a interligação dos sistemas fotovoltaicos às redes de distribuição (PESQUISA FAPESP, 2017).

Ainda, conforme Figura 8 a seguir, que mostra o total diário de irradiação, é observado que a região Nordeste apresenta um grande potencial de irradiação ao longo do ano todo, o que demonstra que a opção por instalações de usinas solares na região é vantajosa. 


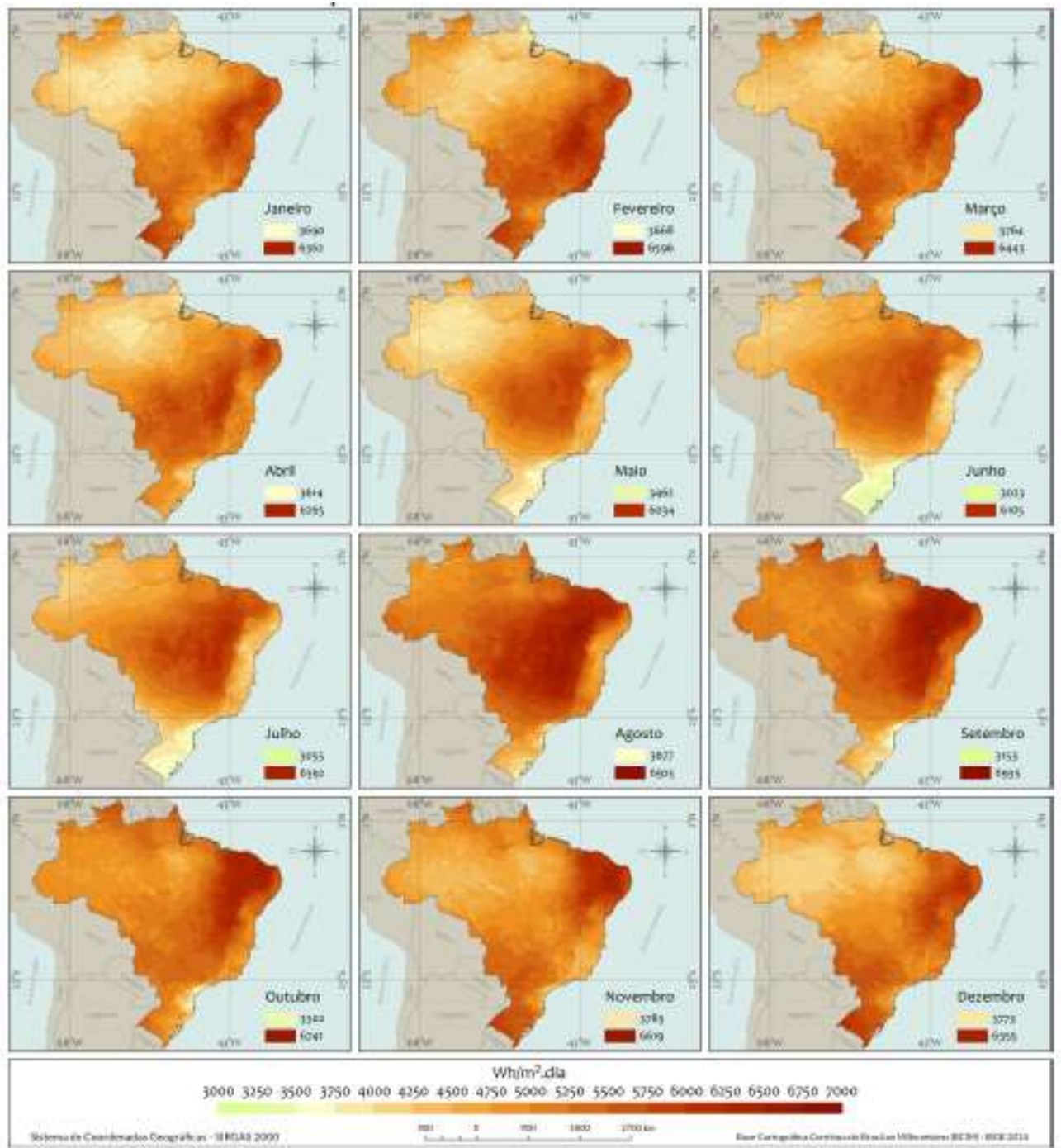

Figura 8 - Total diário da irradiação no plano inclinado na latitude

Fonte: (O ATLAS BRASILEIRO DE ENERGIA SOLAR, 2017).

\subsection{Usinas Solares em Operação no Ceará}

Atualmente, existem 4.259 projetos solares no Brasil, somando um total de 3.113.946,25 $\mathrm{kW}$ de potência instalada. Esse total corresponde a 1,79\% da matriz de eletricidade do país. Embora sua participação ainda seja tímida, ultrapassou a capacidade instalada da fonte nuclear e ainda há muito espaço para crescer.

Do total desse montante instalado, a participação do estado do Ceará é correspondente a 7\% (conforme mostrado na Figura 9) do potencial instalado, com oito projetos em execução, sendo três deles extremamente recentes, de 2019 (SIGA - ANEEL, 2020). 
Tabela 3 - Usinas solares em operação no Ceará

\begin{tabular}{|c|c|c|c|}
\hline Usina & Data Operação & Potência Fiscalizada (kW) & Município \\
\hline Tauá & $01 / 07 / 2011$ & 5.000 & Tauá - CE \\
\hline Apodi I & $28 / 11 / 2018$ & 33.000 & Quixeré - CE \\
\hline Apodi II & $28 / 11 / 2018$ & 33.000 & Quixeré - CE \\
\hline Apodi III & $28 / 11 / 2018$ & 33.000 & Quixeré - CE \\
\hline Apodi IV & $28 / 11 / 2018$ & 33.000 & Quixeré - CE \\
\hline $\begin{array}{c}\text { Sol do Futuro I (Steelcons Sol } \\
\text { do Futuro I) }\end{array}$ & $02 / 03 / 2019$ & 27.000 & Aquiraz - CE \\
\hline $\begin{array}{c}\text { Sol do Futuro II (Antiga } \\
\text { Steelcons Sol do Futuro III) }\end{array}$ & $02 / 03 / 2019$ & 27.000 & Aquiraz - CE \\
\hline $\begin{array}{c}\text { Sol do Futuro III (Antiga } \\
\text { Steelcons Sol do Futuro III) }\end{array}$ & $02 / 03 / 2019$ & 27.000 & Aquiraz - CE \\
\hline \multicolumn{2}{c}{ Total } & 218.000 & \multirow{2}{*}{}
\end{tabular}

\section{PARTICIPAÇÃO - USINA SOLAR NO CEARÁ}

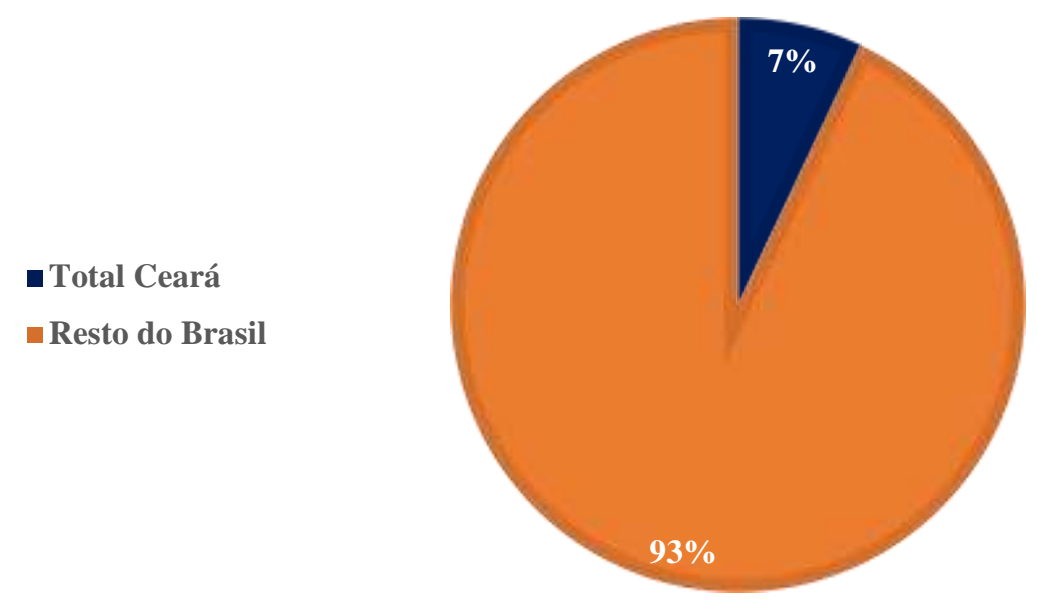

Figura 9 - Participação do Ceará no montante de potência instalada da fonte solar

Fonte: Autoria própria

\subsection{Legislação ambiental no Ceará}

No Ceará, a execução da política estadual de controle ambiental e administração do licenciamento de atividades poluidoras são funções da Superintendência Estadual do Meio Ambiente (Semace), que está vinculada ao Conselho de Políticas e Gestão do Meio Ambiente (Conpam) (MMA,2018). 
Criado a partir da Lei Estadual n 13.875/2007 (CEARÁ, 2007), o Conpam é um órgão colegiado responsável pela formulação e planejamento da política ambiental do estado do Ceará, além de ser o articulador do sistema de gestão estadual. Além desses, há um outro órgão que faz parte do processo de licenciamento ambiental, o Conselho Estadual do Meio Ambiente (Coema/CE), que está vinculado diretamente ao governador. Durante o processo de obtenção das licenças, com a apresentação do EIA/RIMA, o Coema/CE deve ser ouvido pela Semace antes da decisão (MMA, 2018).

Os principais instrumentos legais e normativos que embasam os processos e licenciamento e autorização para intervenção ambiental no estado do Ceará são mostrados na Tabela 4 a seguir:

Tabela 4 - Instrumentos legais que embasam os processos de licenciamento para intervenção ambiental no estado do Ceará

\begin{tabular}{|c|c|c|}
\hline Instrumento Legal & Descrição & Referência \\
\hline $\begin{array}{l}\text { Lei Estadual } n^{\circ} \\
11.411, \text { de } 28 \text { de } \\
\text { dezembro } 1987 \\
\end{array}$ & \begin{tabular}{|c|} 
Dispõe sobre a Política Estadual do Meio Ambiente \\
(Coema/CE) e Superintendência Estadual do Meio Ambiente \\
(Semace) e dá outras providências
\end{tabular} & (CEARÁ, 1987) \\
\hline $\begin{array}{c}\begin{array}{c}\text { Portaria Semace } \mathrm{n}^{\mathrm{o}} \\
154, \text { de } 22 \text { de julho } \\
\text { de } 2002\end{array} \\
\end{array}$ & $\begin{array}{l}\text { Dispõe sobre padrões e condições para lançamento de } \\
\text { efluentes líquidos gerados por fontes poluidoras }\end{array}$ & (CEARÁ, 2002a) \\
\hline $\begin{array}{c}\text { Portaria Semace } \mathrm{n}^{\mathrm{o}} \\
151, \text { de } 25 \text { de } \\
\text { novembro de } 2002 \\
\end{array}$ & $\begin{array}{c}\begin{array}{c}\text { Dispõe sobre normas técnicas e administrativas necessárias à } \\
\text { execução e ao acompanhamento do automonitoramento de } \\
\text { efluentes líquidos industrias }\end{array} \\
\end{array}$ & (CEARÁ, 2002b) \\
\hline $\begin{array}{c}\text { Resolução } \\
\text { Coema/CE n }{ }^{\circ} 8 \text {, de } \\
15 \text { de abril de } 2004 \\
\end{array}$ & $\begin{array}{l}\text { Revisa critérios e parâmetros outrora aplicados aos processos } \\
\text { de licenciamento e autorização ambiental no estado do Ceará }\end{array}$ & (CEARÁ, 2004) \\
\hline $\begin{array}{l}\text { Lei Estadual } n^{\circ} \\
13.875, \text { de } 2 \text { de } \\
\text { fevereiro de } 2007\end{array}$ & $\begin{array}{c}\text { Dispõe sobre a criação do Conselho de Políticas e Gestão do } \\
\text { Meio Ambiente (Conpam) }\end{array}$ & (CEARÁ, 2007) \\
\hline $\begin{array}{c}\text { Instrução Normativa } \\
\text { Semace } n^{\circ} 1 \text {, de } 29 \\
\text { de setembro de } 2010\end{array}$ & $\begin{array}{c}\text { Define normas e procedimentos a serem seguidos nas } \\
\text { diversas etapas e fases do procedimento licenciamento } \\
\text { ambiental dos empreendimentos, obras ou atividades } \\
\text { utilizadoras de recursos ambientais, potencial ou efetivamente } \\
\text { poluidoras, bem como aqueles que causem, sob qualquer } \\
\text { forma, degradação ambiental }\end{array}$ & (CEARÁ, 2010b) \\
\hline $\begin{array}{l}\text { Instrução Normativa } \\
\text { Semace } \mathrm{n}^{\circ} 2 \text {, de } 20 \\
\text { de outubro de } 2010\end{array}$ & $\begin{array}{c}\text { Regula os procedimentos para apuração de infrações } \\
\text { administrativas por condutas e atividades lesivas ao meio } \\
\text { ambiente }\end{array}$ & (CEARÁ, 2010a) \\
\hline $\begin{array}{c}\text { Resolução } \\
\text { Coema/CE n }{ }^{\circ} 20, \text { de } \\
28 \text { de outubro de } \\
2010 \\
\end{array}$ & $\begin{array}{c}\text { Estabelece procedimentos para a exigência do documento de } \\
\text { outorga do uso da água no curso do licenciamento ambiental, } \\
\text { promovido pela Semace }\end{array}$ & (CEARÁ, 2010c) \\
\hline $\begin{array}{l}\text { Lei Estadual } n^{\circ} \\
14.882 \text {, de } 31 \text { de } \\
\text { janeiro de } 2011\end{array}$ & $\begin{array}{c}\text { Dispõe sobre procedimentos ambientais simplificados para } \\
\text { implantação e operação de emprrendimentos e/ou atividades } \\
\text { de porte micro com potencial poluidor degradador baixo }\end{array}$ & (CEARÁ, 2012) \\
\hline $\begin{array}{c}\text { Resolução } \\
\text { Coema/CE n } 4 \text {, de } \\
12 \text { de abril de } 2012\end{array}$ & $\begin{array}{c}\text { Dispoõe sobre a atualização dos procedimentos, critérios, } \\
\text { parâmetros e custos aplicados aos processos de licenciamento } \\
\text { e autorização ambiental na Superintendência Estadual do Meio } \\
\text { Ambiente (Semace) }\end{array}$ & (CEARÁ, 2012) \\
\hline
\end{tabular}

Fonte: MMA, 2018. 


\subsection{Resoluções Normativas para Licenciamento Ambiental no Ceará de projetos de energia solar}

Em 3 de março de 2016, foi aprovada a Resolução COEMA nº 3, que dispõe sobre critérios e procedimentos simplificados para sistemas de micro e mini geração distribuída de energia elétrica a partir de fontes renováveis, sendo que os requisitos da mesma são resumidos a seguir:

Tabela 5 - Critérios para o licenciamento ambiental de empreendimentos de micro e mini geração fotovoltaica no Ceará

\begin{tabular}{|c|c|c|}
\hline Potência Nominal & Área de Instalação & Processo de Licenciamento \\
\hline Menor ou igual a $75 \mathrm{~kW}$ & Área que não interfere em APP ou UC & $\begin{array}{c}\text { Isento de Licença (caso necessário, } \\
\text { pode ser emitida Declaração de } \\
\text { Isenção) }\end{array}$ \\
\hline Acima de $75 \mathrm{~kW}$ e até $2 \mathrm{MW}$ & Área urbana ou rural, sobre telhado ou fachada & $\begin{array}{c}\text { Isento de Licença (caso necessário, } \\
\text { pode ser emitida Declaração de } \\
\text { Isenção) }\end{array}$ \\
\hline Acima de 2 MW e até $3 \mathrm{MW}$ & Área urbana ou rural & $\begin{array}{c}\text { Obrigado a fazer a autodeclaração } \\
\text { online (preenchida pelo interessado) }\end{array}$ \\
\hline Acima de 3 MW e até $5 \mathrm{MW}$ & Área urbana ou rural & $\begin{array}{c}\text { Requer licença ambiental simplificada } \\
\text { (prazo de 60 dias) }\end{array}$ \\
\hline Acima de $5 \mathrm{MW}$ & Qualquer área & $\begin{array}{c}\text { Não há processo simplificado (requer } \\
\text { EIA/RIMA) }\end{array}$ \\
\hline
\end{tabular}

Fonte: Resolução COEMA 03/2016, adaptado.

Dessa maneira, acima de uma potência nominal de 5MW, o empreendimento requer um EIA/RIMA, já que não se enquadra em um caso simplificado, independente da área onde será instalado o projeto.

Mais recentemente, o Conselho Estadual do Meio Ambiente (COEMA) modernizou e estabeleceu novos critérios para o processo de licenciamento ambiental para empreendimentos de energia solar, o que agiliza os processos, além de desencadear mais oportunidade em energias renováveis no Ceará, atraindo novos investimentos e propiciando melhores condições para o desenvolvimento de projetos desse tipo de usina, também aumentando as possibilidades de os empreendimentos cearenses serem contratados em leilões.

A resolução COEMA n ${ }^{\circ}$ 06, de 6 de setembro de 2018, que concede um marco regulatório para o setor, estabelecendo procedimentos e conteúdos mínimos para estudos atrelados ao licenciamento ambiental de empreendimentos de geração de energia elétrica a partir de fonte solar fotovoltaica no Ceará, permite que o estado tenha uma regulamentação para licenciamento 
ambiental, tanto na geração distribuída (até $5 \mathrm{MW}$ ) quanto na centralizada (acima de $5 \mathrm{MW}$ ) mais definida.

A resolução estabelece normas, critérios e padrões relativos ao controle de manutenção da qualidade do meio ambiente enfatizando a utilização, preservação e conservação dos recursos ambientais.

O Potencial Poluidor-Degradador - PPD do empreendimento, obra ou atividade objeto do licenciamento ou autorização ambiental classifica-se como Baixo (B), Médio (M) ou Alto (A). O potencial poluidor dos investimentos de geração de energia elétrica a partir da fonte solar fotovoltaica são estabelecidos da seguinte forma:

Tabela 6 - Potencial poluidor de empreendimentos de energia solar fotovoltaica

\begin{tabular}{|l|c|c|c|c|c|c|}
\hline Energia Solar/Fotovoltaica & \multicolumn{5}{|c|}{ Porte - Área (Hectare) } \\
\hline Potencial Poluidor & Baixo & $\mathrm{Mc}>15<=30$ & $\mathrm{Pe}>30<=90$ & $\mathrm{Me}>90<=180$ & $\mathrm{Gr}>180<=450$ & $\mathrm{Ex}>450$ \\
\hline
\end{tabular}

Fonte: Resolução COEMA No 6 DE 06/09/2018 - adaptado. Sendo: Mc = micro; Pe = pequeno; $\mathrm{Me}=$ médio; $\mathrm{Gr}=$ grande $; \mathrm{Ex}=$ excepcional .

Não será exigida licença/autorização ambiental para a obra ou atividade que se enquadre abaixo do valor apontado como limite mínimo para respectiva obra ou atividade, sendo classificada como porte menor que micro $(<\mathrm{Mc})$.

Considerando o porte, a localização e o baixo potencial poluidor serão seguidos os seguintes procedimentos de licenciamento ambiental:

- Para os portes micro, pequeno, médio e grande a licença ambiental será emitida em duas etapas: Licença Prévia (LP) e Licença de Instalação juntamente com a de Operação (LIO)

- Para o porte excepcional, a licença ambiental será emitida em três etapas: Licença Prévia (LP), Licença de Instalação (LI) e Licença de Operação (LO)

O prazo de análise e emissão das licenças será de até 45 dias, contabilizados a partir da data 
de protocolização do requerimento da Licença Prévia ou de no máximo 45 dias contabilizados a partir da data da protocolização da referida Licença de Instalação e Operação (LIO).

Os empreendimentos solares de porte excepcional não serão considerados de baixo impacto, exigindo-se então a apresentação de Estudo de impacto Ambiental e respectivo Relatório de Impacto Ambiental (EIA/RIMA) com comprovação de inexistência de alternativa técnica e locacional dos projetos além de audiências públicas, que estiverem localizados em:

1. Formações dunares, planícies fluviais e de deflação, mangues e demais áreas úmidas;

2. Bioma Mata Atlântica e implicar corte e supressão de vegetação primária e secundária no estágio avançado de regeneração;

3. Zona Costeira e implicar alterações significativas das suas características naturais;

4. Zonas de amortecimento de unidades de conservação de proteção integral, adotando-se o limite de $3 \mathrm{~km}$ a partir do limite da unidade de conservação, cuja zona de amortecimento não esteja ainda estabelecida;

5. Áreas regulares de rota, pouso, descanso, alimentação e reprodução de aves migratórias que estejam no Relatório Anual de Rotas e Áreas de Concentração de Aves Migratórias no Brasil, a ser emitido pelo Instituto Chico Mendes de Conservação da Biodiversidade - ICMBio, em até 90 dias;

6. Locais em que venham a gerar impactos socioculturais diretos que impliquem na inviabilização de comunidades ou sua completa remoção;

7. Áreas de ocorrência de espécies ameaçadas de extinção e áreas de endemismo restrito, conforme listas oficiais.

Nos casos em que houver conflitos socioambientais ou que haja comunidade significativa afetada deverá ser realizada uma Reunião Técnica Informativa, às custas do empreendedor.

Os empreendimentos de geração de eletricidade a partir de fonte solar em que seja exigido 
um EIA/RIMA estarão sujeitos ao pagamento da Compensação Ambiental, conforme estabelecido pela Lei Federal n ${ }^{\circ}$ 9.985/2000

Nos casos de sistemas híbridos, deverá ser apresentado um único RAS, com informações de todas as atividades, modalidades e fontes envolvidas. Os testes pré-operacionais e atividades de comissionamento deverão estar definidos no cronograma de instalação do empreendimento, e tais atividades deverão ser precedidas de comunicação à SEMACE.

A análise técnica dos processos sujeitos à apresentação de RAS será feita pela SEMACE, nos termos da Resolução COEMA nº 06/2018 por uma equipa multidisciplinar de ao menos três técnicos nas fases iniciais de licenciamento de Licença Prévia e Licença de Operação.

A Instrução Normativa $n^{\circ}$ 01/2018 estabelece procedimentos e conteúdo mínimo para estudos atrelados ao licenciamento ambiental de empreendimentos de geração de energia elétrica a partir de fonte solar fotovoltaica e eólica em superfície terrestre, previstos na Resolução COEMA nº6, de 06 de setembro de 2018 e Resolução COEMA nº7, de 06 de setembro de 2018, respectivamente, no estado do Ceará

Essa Instrução Normativa foi divulgada pelo Diário Oficial do Estado - Série 3 - ano x nº218 - Fortaleza, em 22 de novembro de 2018 e nela é apresentada uma proposta de conteúdo mínimo para o Relatório Ambiental Simplificado (RAS).

\subsection{O Processo de Licenciamento de Usinas Solares Fotovoltaicas no Ceará}

De acordo com Juliana Louyza de Souza Cavalquante Aquino, coordenadora da área socioambiental na empresa Quadran Brasil Participações LTDA localizada no Ceará, o processo de licenciamento ambiental no estado é iniciado com a licença prévia (LP) juntamente com um Relatório Ambiental Simplificado (RAS), que é necessariamente o estudo a ser apresentado para dar entrada ao processo da licença prévia no Ceará.

A licença prévia tem a função fundamental de avaliar a viabilidade ambiental do empreendimento, analisando seus impactos sociais e ambientais e a possibilidade de mitigá-los. A validade dessa licença não pode ser superior a cinco anos e deve estar de acordo, no mínimo, 
com o prazo estabelecido para o planejamento do projeto em seu cronograma de elaboração, de acordo com a Resolução CONAMA 237/1997.

O processo de licenciamento ambiental é feito pelo site da SEMACE. Toda a documentação é enviada pelo processo online. A SEMACE (órgão licenciador do Ceará), analisa a documentação e gera guia para pagamento da licença. Caso algum documento não seja aceito, a SEMACE abre uma pendência e explica por meio de uma mensagem qual o ponto que a fez invalidar o documento. Neste caso, o empreendedor tem então um prazo para enviar a documentação adequada. Após confirmação do pagamento e validação de todos os documentos encaminhados, o processo é gerado. Assim, é iniciado o processo de análise pelo técnico.

Sendo um processo que siga com um RAS, o técnico vai fazer a vistoria, analisar o relatório e emitir a LP. Em seguida, deve-se cumprir as condicionantes da LP e será aberto dessa forma o processo de LIO, protocolando a documentação online, cumprindo um checklist de licenciamento com os documentos necessários, gerando então o guia para pagamento da licença.

As condicionantes dizem respeito aos compromissos que o empreendedor assume junto aos órgãos ambientais, para então manter as licenças ambientais. Estas asseguram a sustentabilidade do empreendimento e podem ser gerais ou específicas. As condicionantes gerais dizem respeito às exigências legais que estão relacionadas ao licenciamento ambiental, já as específicas estão relacionadas ao conjunto de exigências e restrições técnicas particulares à atividade a ser licenciada.

Sendo um processo que precise de um estudo mais completo, caso o porte do empreendimento seja considerado como excepcional, conforme a legislação vigente, o procedimento vem com uma condicionante de que no ato do requerimento da licença de instalação é necessária a apresentação de um EIA/RIMA, além do PBA (Plano Básico Ambiental) também incluso. Esse processo é comumente chamado de LP para leilão, e vai emitir a LP com uma condicionante para apresentação do EIA/RIMA, necessário no pedido da LI. Em 45 dias, contados a partir da entrega deste relatório, faz-se assim a publicação da audiência pública, necessária para que o empreendimento seja aprovado. 
Estabelecida pelas Resoluções Conama 01/86 e 09/87, a audiência pública é o principal instrumento de participação social que há em um processo de licenciamento, tornando transparente esse processo para a sociedade, as peculiaridades e relevância do empreendimento. Durante a audiência, dúvidas são esclarecidas, críticas são formuladas e sugestões são concedidas. Uma vez solicitada a audiência pública para o processo de licenciamento, ela se torna obrigatória. Dessa forma, caso não seja realizada não há obtenção de licença e o projeto então não inicia suas atividades.

A audiência pública, que deve ocorrer em local de fácil acesso aos interessados, possui uma ata que pode servir de base para o parecer final sobre a licença solicitada, juntamente com os estudos ambientais realizados. Nelas, são apresentados ao COEMA pareceres técnicos pelo SEMACE referentes aos meios físico, biótico, social e antrópico, indicando assim após análise se o empreendimento é viável ou não para o processo, para então apresentar um parecer final de EIA/RIMA, consolidando os anteriores, o que leva a embasar a aprovação do projeto. Devese estar com todas as autorizações que possam ser necessárias, como do IPHAN (Instituto do Patrimônio Histórico e Artístico Nacional), do COMAER (Comando da Aeronáutica), do ICMBIO (caso o empreendimento esteja em alguma unidade de proteção ambiental que seja de administração federal), do resgate de fauna, do manejo de fauna e de supressão vegetal

Com o relatório final, pode-se solicitar a licença de operação, cumprindo-se todas as condicionantes da licença de instalação. Caso as condicionantes não sejam atendidas durante essa fase, o pedido de licença pode ser suspenso ou até mesmo cancelado.

O empreendedor que apresente um projeto que necessita da apresentação do EIA/RIMA deve firmar o termo de compensação ambiental, quitá-lo para poder pedir a Licença de Operação. É importante destacar que o termo de compensação ambiental no Ceará é firmado na Secretaria Estadual do Meio Ambiente e não na SEMACE.

Assim, faz-se o requerimento da Licença de operação (LO), tendo sido emitidas todas as anteriores. Esta deve ser solicitada após verificação da SEMACE do cumprimento de todas as medidas estabelecidas pelas licenças anteriores, assim como a verificação das medidas de controle ambiental propostas. Essa licença autoriza o início da operação do empreendimento e tem uma validade entre 4 a 10 anos, dependendo do projeto (CONAMA 237, 1997). 
Os custos a serem pagos pelas licenças e pelos estudos ambientais são de responsabilidade de seus solicitantes. Os custos operacionais pagos pelo empreendedor terão de estar de acordo com a resolução COEMA No 10/2015, de acordo com o porte e potencial poluidor da atividade, e terão de corresponder ao resultado da multiplicação da unidade Federal de Referência (UFIRCE), ou índice substituto, pelos respectivos coeficientes.

Em qualquer momento em que sejam verificadas inconsistências e irregularidades pela SEMACE, como informações falsas, graves impactos ambientais presentes, alterações não notificadas para o órgão etc., a licença pode ser cancelada.

O prazo da renovação das licenças ambientais deve obedecer ao mesmo procedimento de sua obtenção, assim como a validade das mesmas e seus custos. A renovação da licença deve ser solicitada no mínimo 120 dias antes de sua validade. Caso esse prazo não seja cumprido, irá ser configurada uma infração ambiental, com penas previstas na Lei para o infrator.

Ao ser entregue ao empreendedor as licenças, ele é então responsável pelos compromissos que deverão ser assegurados para sua manutenção, ou seja, fica encarregado de garantir a qualidade ambiental no local do empreendimento. Caso as condicionantes sejam descumpridas, deverão ser pagas multas aos cofres públicos, além de perder a licença. 


\section{CONSIDERAÇÕES FINAIS}

A temática do licenciamento ambiental pode gerar muitos conflitos, discordâncias e então, por consequência, muitos problemas para o andamento do processo também. Dentre as dificuldades que comumente são encontradas, há as de caráter normativo, estrutural e de característica da população. Há uma postura de competição entre os entes envolvidos, quando há a necessidade de se ter uma regulação do processo ambiental que seja desenvolvida em conjunto entre estes.

Um dos principais problemas encontrados no processo de licenciamento ambiental é a ausência de normativa federal para licenciamento de usinas solares fotovoltaicas, o que faz com que o gestor ambiental não tenha inicialmente o suporte necessário para avaliação do estudo a ser realizado, ficando a critério deste os parâmetros a serem seguidos, uma vez que não há um direcionamento claro advindo das normas existentes. Outro problema recorrente é o conflito de competências, que ocorre em virtude da falta de clareza em relação ao ordenamento jurídico para definição das competências para a regulação ambiental, podendo ser solicitado o IBAMA, os OEMAs ou os OMMAs, o que acaba gerando muitas dúvidas dessa forma sobre a distribuição das mesmas, qual esfera é responsável pelo licenciamento etc., dificultando então o processo.

A problemática tem origem na Política Nacional do Meio Ambiente, lei 6938/81, uma vez que a mesma divide a competência do licenciamento entre os entes federais, estaduais e municipais. Apesar de se ter assim uma república consistente, na prática esse nunca foi o perfil brasileiro, já que os estados, de forma geral, não possuem uma estrutura organizada e suficiente, de forma que pudessem tratar as diversas questões existentes no processo de licenciamento ambiental.

Assim sendo, sem uma estruturação bem fundamentada no estado, a União acaba intervindo constantemente nas questões, o que pode ocasionar um problema em função de uma atuação motivada por interesses, levando em conta que o Brasil tem uma situação política frágil, com agravante de corrupção frequente, podendo então abrir espaço para atendimento de interesses. Ainda que haja motivação por parte dos estados, a ausência de uma definição clara sobre as competências a serem responsáveis pelo processo para licenciar, fiscalizar e punir acaba gerando um ambiente desordenado e, por isso, desfavorável para a criação de projetos. 
A lei complementar $n^{\circ} 140$, de 8 de dezembro de 2011 regulamentou o art. 23 da Constituição Federal/88, com o objetivo de fixar normas para a cooperação entre os entes federativos nas ações administrativas relacionadas à proteção do meio ambiente e ao combate à poluição. A lei promove a gestão descentralizada de forma que não haja a sobreposição de atuação. Em relação à aplicação prática, os entes federativos não podem atuar de forma autônoma sobre as matérias discriminadas no art 23 da CF, de maneira cumulativa e sobreporse uns aos outros, o que acaba dificultando uma atuação simultânea dos entes em prol da defesa do meio ambiente.

Outro problema encontrado e que dificulta muitas vezes o processo é a deficiência de conhecimento técnico científico, de uma maneira geral, verificado tanto nos órgãos ambientais quanto nos responsáveis pelos estudos a serem realizados, ficando assim a cargo do fiscal a avaliação, sem uma delimitação mais técnica anterior. Como consequência, a qualidade de alguns estudos de impactos ambientais pode ficar prejudicada, sem trabalhos científicos aprofundados sobre os impactos e sem parâmetros técnicos bem definidos como base de comparação. Dessa forma, quando iniciado o processo de licenciamento, é recorrente a necessidade de condicionantes nas licenças ambientais, o que acaba gerando então atrasos no processo. Ainda mais considerando usinas fotovoltaicas, já que não é abrangente o conhecimento acerca desse tipo de fonte e por ser relativamente recente.

Outro ponto importante a ser mencionado é o fato de que há um vínculo contratual entre a empresa executora do relatório de impacto ambiental e o interessado no empreendimento, o que pode fazer com que haja suspeita dos dados apresentados referentes à avaliação de impacto ambiental. Tal fato pode ser muito prejudicial para o meio ambiente, visto que há a possibilidade de não se ter uma análise completa dos impactos ambientais e suas respectivas ações mitigadoras. É essencial que esse tipo de estudo seja estritamente imparcial e transparente.

Outro problema que é frequentemente evidenciado é a falta de planejamento integrado, que é uma medida que auxilia para que haja um bom controle ambiental, promovendo o desenvolvimento econômico sustentável da região a ser afetada pelo empreendimento. Para isso, é necessário que se tenha uma análise dos possíveis empreendimentos que a região possa vir a ter, a viabilidade dos mesmos e o retorno que trarão para a região. 
Entretanto, no Brasil não se tem uma avaliação ambiental estratégica integrada, de forma que sejam consideradas as demandas da região para seu desenvolvimento sustentável, bem como as ações de mitigação dos impactos ambientais. O tratamento das questões relacionadas ao meio ambiente é tratado de forma isolada, visando apenas as emissões das licenças para que o empreendimento seja aprovado. Se fosse feito um planejamento integrado, haveria a análise de possível outra atividade que trouxesse benefícios ambientais e econômicos.

Ainda, o sistema de controle ambiental no Brasil é voltado para o processo de licenciamento de atividades, sem ser dada a devida importância para o acompanhamento destas. Em outras palavras, o sistema normativo é focado nos procedimentos para a aquisição das licenças, sem priorizar da mesma forma o acompanhamento das atividades e o cumprimento das medidas de controle ambiental depois de obtidas as licenças.

Isso ocorre em virtude de que a preocupação principal não é com as medidas requisitadas no processo de mitigação dos impactos ambientais advindos da atividade, mas sim com as necessárias para que se tenha a obtenção das licenças. Como consequência, pouco se sabe sobre a efetividade da regulação ambiental. Apenas quando está próximo do período de renovação de licença que se tem uma preocupação com a atividade novamente, para avaliar se a atividade está cumprindo com os procedimentos solicitados e ter então sua licença renovada.

Entretanto, dessa forma se algum impacto nocivo já foi causado ele será repercutido por um tempo. Por isso, um acompanhamento da atividade é muito importante para assegurar a defesa do meio ambiente. A principal causa dessa situação é a gestão dos órgãos ambientais, muitas vezes com reduzido número de funcionários para que se possa acompanhar, de maneira efetiva, todos os empreendimentos cujas licenças já tenham sido concedidas.

Outra questão que é importante de ser destacada é que eventualmente é necessária a consulta de diversos órgãos, o que pode tornar o processo burocrático e pouco eficiente, sem uma centralização dos procedimentos. Dependendo da localização do empreendimento, do impacto causado etc., podendo até intervir em órgãos de outras instâncias. Por exemplo, órgãos responsáveis pelas unidades de conservação afetadas, pelo patrimônio histórico, gestão das águas etc. 
Algumas medidas podem ser utilizadas para solucionar os problemas mencionados. A regulamentação dos princípios do direito ambiental é uma medida essencial para que se tenha uma proteção ambiental efetiva e segura. Com definições objetivas, não há espaço para que fatores que não sejam técnicos impactem de alguma forma, tornando assim o processo mais eficiente.

Inicialmente, é indicado que se crie parâmetros, de tal forma que haja a delimitação das decisões dos entes envolvidos no licenciamento. Como este é um ambiente muito discricionário, há uma necessidade de que as normas sejam claras, com definições de limites dos impactos ambientais e regulando as ações mitigadoras.

Outra questão que auxiliaria no processo é a aprovação de normas que definam, de maneira objetiva, quais as competências atribuídas a cada esfera (federal, estadual e municipal) para acompanhamento do licenciamento, responsabilizando dessa forma os órgãos ambientais de cada um deles, tanto no âmbito administrativo como normativo. Para isso, deve-se levar em consideração as limitações de cada ente envolvido, de forma que haja um ambiente colaborativo entre eles, que deixaria todo o processo mais rápido e eficiente.

Ainda, seria importante também uma padronização das normas entre os estados, tornando dessa forma mais simples o processo de fiscalização pelos órgãos competentes, reduzindo assim também o ambiente de competição entre eles, focando assim apenas no objetivo final de assegurar a proteção do meio ambiente. Essas padronizações precisam visar a simplificação do processo de licenciamento ambiental, de forma que este seja mais transparente para a sociedade e para os investidores, facilitando a eficiência do processo, do ponto de vista burocrático, e assegurando a efetividade do controle ambiental.

Para minimizar problemas na regulação ambiental, uma solução que poderia ser benéfica é passar o desenvolvimento do conhecimento das atividades a serem licenciadas a um órgão independente, sem nenhum vínculo com o empreendedor que pretende obter o licenciamento. Dessa forma, a parte independente é a detentora do conhecimento e tem a única preocupação de assegurar a qualidade ambiental, minimização e mitigação de impactos ambientais negativos, sendo responsáveis não apenas pelos estudos, mas sobre toda a atividade, assim como é feito na Alemanha. Com isso, os órgãos reguladores auxiliariam o empreendedor no desenvolvimento de atividades que culminariam nos relatórios de impacto ambiental, 
facilitando dessa forma o acompanhamento dos empreendimentos que adquiriram as licenças, tornando assim possível uma fiscalização mais eficiente.

Dessa forma, seria possível reduzir então influências políticas no processo de licenciamento ambiental, passando as atribuições dos estudos para um órgão de amplo conhecimento técnico e científico, que ficariam responsáveis ainda pelas consequências adversas após liberação das licenças, o que iria fazer com que assegurassem dessa forma a eficácia das medidas solicitadas.

Ainda, seria interessante a criação de mais cursos específicos orientados à energia solar, voltados não apenas à Pós-Graduação mas também à Graduação, de forma que atenda então à esta demanda de conhecimento técnico científico na área.

A centralização do processo de regulação ambiental também traria benefícios, eliminando assim a necessidade de exigir consulta de diversos órgãos reguladores. Com as definições técnicas estabelecidas, apenas um órgão estaria encarregado de fazer cumprir os procedimentos requeridos. Assim, este órgão poderia também acompanhar o empreendimento após a concessão da licença de operação, assegurando o cumprimento por parte da empresa de todas as medidas solicitadas para a obtenção das licenças.

O caso do Ceará, que foi analisado de forma comparativa nesse trabalho, apresenta uma normatização específica para esse tipo de projeto, que abrange até os híbridos eólico-solar, o que faz com que sirva de exemplo a ser seguido para demais estados que ainda não possuam uma regulamentação específica para esse tipo de empreendimento.

Assim como já mencionado anteriormente, o processo de licenciamento ambiental das usinas solares fotovoltaicas no Brasil possui deficiências em relação a normatização e padronização entre os entes federativos. Essa questão é resultante do fato de que a primeira usina solar fotovoltaica foi instalada em 2011, porém as legislações que abrangem o licenciamento ambiental são mais antigas, assim como a avaliação de impacto ambiental, e não abrangem os sistemas fotovoltaicos. Por isso, a nível federal o licenciamento ambiental desse tipo de empreendimento não possui uma regulamentação específica.

Entretanto, o Ceará já dispõe de uma regulamentação estadual de licenciamento ambiental para empreendimentos de energia solar fotovoltaica com a Resolução COEMA nª 6/2018, 
simplificando então os procedimentos e, concedendo assim, um direcional mais claro de como proceder para aquisição de licenciamento ambiental desse tipo de empreendimento no estado.

Através dessa Resolução, é possível verificar que no estado a exigência de um estudo complexo e, por consequência, mais detalhado e que demanda um tempo maior e, portanto, uma organização maior, é para áreas acima de 450 hectares ou áreas sensíveis conforme dispõe a Resolução, ou seja, é possível afirmar que a legislação estadual é mais branda do que a CONAMA 01/86. Com essa regulamentação, o estado do Ceará passou a ser mais atrativo para o investimento nesse tipo de fonte.

Ainda, é importante ressaltar que apesar disso há o caráter discricionário e, de acordo com a área requerida para licenciamento e intervenções do projeto, podem surgir pedidos de complemento do estudo dependendo da análise, já que nenhum licenciamento ambiental é linear, cada um tem suas particularidades que devem ser consideradas.

Uma observação importante a ser mencionada é que após as vantagens acerca das Tarifas de Uso dos Sistemas de Transmissão (TUST) e de Distribuição (TUSD), que oferece descontos nessas tarifas para empreendimentos em que a potência injetada nos sistemas de distribuição e de transmissão seja equivalente ou menor do que $30.000 \mathrm{~kW}$, as usinas começaram a não serem construídas com um potencial acima deste valor, mesmo que sejam do mesmo complexo fotovoltaico, ou seja, possivelmente em virtude da aquisição desses descontos concedidos.

Além disso, há ainda a possibilidade de venda direta, sem intermediação de distribuidoras, das geradoras de energia solar com potência inferior a $50.000 \mathrm{~kW}$, para consumidores especiais que irão então se beneficiar com o desconto na TUSD, ou seja, tornando então a compra a partir desse tipo de fonte ainda mais atrativa.

Em relação à trabalhos futuros relacionados ao tema, complementando o conhecimento sobre este, pode-se recomendar uma análise mais aprofundada das normas, de forma a determinar se os parâmetros impostos são suficientes para garantir a manutenção da sustentabilidade da área que será afetada pelo novo empreendimento. Ainda, seria interessante uma análise de possíveis procedimentos para acompanhamento da região afetada pela usina solar, de forma que assegure então a boa manutenção desta não apenas para emissão das licenças. 
Além disso, é fundamental uma análise sobre o ciclo de vida dos materiais usados nas usinas solares, verificando dessa forma o real impacto que esta exerce sobre o meio ambiente, desde a fabricação das células fotovoltaicas até o descomissionamento da usina. Como ainda é uma tecnologia relativamente recente, ainda há muito a ser estudado sobre essa questão. Atrelado à isso, seria interessante verificar os diferentes tipos de tecnologia das células já existentes e quais as vantagens sobre seus usos do ponto de vista ambiental, uma vez que grande parte das células utilizadas nos módulos fotovoltaicos são feitas de silício, cujo processo de extração exerce um grande impacto ambiental.

Por fim, é importante também uma atenção à etapa de descomissionamento da usina fotovoltaica, uma vez que por ser uma tecnologia ainda recente não é amplamente estudado os impactos advindos de sua desativação, com os resíduos finais gerados a partir deste processo. 


\section{REFERÊNCIAS BIBLIOGRÁFICAS}

ABSOLAR - Associação Brasileira de Energia Solar Fotovoltaica - Energia Solar Fotovoltaica: Panorama, Oportunidades e Desafios. Natal - RN, 2017. Disponível em: < http://viexamericas.com/2016/wp-content/uploads/2017/02/RODRIGO-LOPES-2017.02.08-

ABSOLAR-Energia-Solar-Fotovoltaica-Dr.-Rodrigo-Lopes-Sauaia.pdf $>$ Acesso em 15 de janeiro de 2019.

ABSOLAR - Associação Brasileira de Energia Solar Fotovoltaica -Energia Solar Fotovltaica: Leilões A-6 e Realização de LER 2018. Brasília - DF, 2018. Disponível em: < https://www2.camara.leg.br/atividade-legislativa/comissoes/comissoespermanentes/cme/audiencias-publicas/2018/20-06-2018-esclarecer-a-nao-inclusao-da-energiasolar-fotovoltaica-no-leila-a-6-2018-1/apresentacoes/3_ABSOLAR\%20\%20Energia\%20Solar\%20Fotovoltaica\%20-\%20Ricardo\%20Barros_rev02.pdf> Acesso em 15 de janeiro de 2019.

AGÊNCIA NACIONAL DE ENERGIA ELÉTRICA (ANEEL). Atlas da Energia Elétrica do Brasil. Brasília - $\quad$ DF, 2005. $2^{\mathrm{a}}$ Edição. Disponível em: http://www.aneel.gov.br/aplicacoes/Atlas/download.htm. 23 de fevereiro de 2019.

AGÊNCIA NACIONAL DE ENERGIA ELÉTRICA (ANEEL). Energia Solar, pg 29-42. Disponível em <http://www.aneel.gov.br/aplicacoes/atlas/pdf/03-Energia_Solar(3).pdf>. Acesso em: 23 de fevereiro de 2019.

AGÊNCIA NACIONAL DE ENERGIA ELÉTRICA (ANEEL). Sistema de Informações de Geração da ANEEL - SIGA. Disponível em: < siscg@aneel.gov.br>. Acesso em: 07 de outubro de 2020 .

AGÊNCIA NACIONAL DE ENERGIA ELÉTRICA (ANEEL). Banco de Informações de Geração.

Disponível em:

http://www2.aneel.gov.br/aplicacoes/capacidadebrasil/capacidadebrasil.cfm>. Acesso em: 23 de fevereiro de 2019. 
AGÊNCIA NACIONAL DE ENERGIA ELÉTRICA (ANEEL). Resumo Geral dos Novos Empreendimentos de Geração. Disponível em: < http://www.aneel.gov.br/acompanhamentoda-expansao-da-oferta-de-geracao-de-energia-eletrica $>$. Acesso em: 23 de fevereiro de 2019.

AGÊNCIA NACIONAL DE ENERGIA ELÉTRICA (ANEEL). Atlas da Energia Elétrica do Brasil. Brasília - $\quad$ DF, 2005. 2a $2^{\mathrm{a}}$ Edição. Disponível em: http://www.aneel.gov.br/aplicacoes/Atlas/download.htm. Acesso em 23 de fevereiro de 2019.

AGÊNCIA NACIONAL DE ENERGIA ELÉTRICA (ANEEL). Nota Técnica nº 0025/2011, de 20 de junho de 2011. Proposta de abertura de Audiência Pública para o recebimento de contribuições visando reduzir as barreiras para a instalação de geração distribuída de pequeno porte, a partir de fontes incentivadas, conectada em tensão de distribuição e também alteração do desconto na TUSD e TUST para usinas com fonte solar. Disponível em: http://www.aneel.gov.br/aplicacoes/audiencia/arquivo/2011/042/documento/nota_tecnic a_0025_gd.pdf. Acesso em 03 de março de 2019.

AGÊNCIA NACIONAL DE ENERGIA ELÉTRICA (ANEEL). Nota Técnica nº 0163/2012, de 16 de novembro de 2012. Proposta de abertura de Audiência Pública para o recebimento de contribuições visando retificar a Resolução Normativa $n^{0}$ 482/2012. Disponível em: http://www.aneel.gov.br/aplicacoes/audiencia/arquivo/2012/100/documento/nota_tecnic a_0163_srd.pdf. Acesso em 15 de dezembro de 2018.

AGÊNCIA NACIONAL DE ENERGIA ELÉTRICA (ANEEL). Nota Técnica nº 0056/2017SRD. Atualização das projeções de consumidores residenciais e comerciais com microgeração solar fotovoltaicos no horizonte 2017-2024. Disponível em: $<$ http://www.aneel.gov.br/documents/656827/15234696/Nota+T\%C3\%A9cnica_0056_PR OJE\%C3\%87\%C3\%95ES+GD+2017/38cad9ae-71f6-8788-0429-d097409a0ba9>. Acesso em 20 de outubro de 2018.

AGÊNCIA NACIONAL DE ENERGIA ELÉTRICA (ANEEL). Relatório de Análise de Contribuições: Análise de Contribuições Referente à Audiência Pública no 042/2011. Disponível em: http://www.aneel.gov.br/aplicacoes/audiencia/arquivo/2011/042/resultado/relatorio_de_ analise_de_contribuicoes_ap_42_2011_resolucao_final.pdf. Acesso em 26 de abril de 2018. 
AGÊNCIA NACIONAL DE ENERGIA ELÉTRICA (ANEEL). Resolução Normativa ANEEL $\mathrm{n}^{\mathrm{o}}$ 488, de 15 de maio de 2012 de novembro de 2007. Estabelece as condições para revisão dos planos de universalização dos serviços de distribuição de energia elétrica na área rural. Disponível em: http://www.aneel.gov.br/cedoc/ren2012488.pdf. Acesso em 28 de abril de 2018.

AGÊNCIA NACIONAL DE ENERGIA ELÉTRICA (ANEEL). Resolução Normativa $n^{\circ}$ 481, de 17 de abril de 2012. Altera a Resolução Normativa n ${ }^{\circ}$ 77, de 18 de agosto de 2004. Disponível em: http://www.aneel.gov.br/cedoc/ren2012481.pdf. Acesso em 20 de outubro de 2018.

AGÊNCIA NACIONAL DE ENERGIA ELÉTRICA (ANEEL). Resolução Normativa $n^{\circ} 482$, de 17 de abril de 2012. Estabelece as condições gerais para o acesso de microgeração e minigeração distribuída aos sistemas de distribuição de energia elétrica, o sistema de compensação de energia elétrica, e dá outras providências. Disponível em: http://www.aneel.gov.br/cedoc/ren2012482.pdf. Acesso em 19 de maio de 2018.

AGÊNCIA NACIONAL DE ENERGIA ELÉTRICA (ANEEL). Resolução Normativa $n^{\circ} 493$, de 5 de junho de 2012. Estabelece os procedimentos e as condições de fornecimento por meio de Microssistema Isolado de Geração e Distribuição de Energia Elétrica - MIGDI ou Sistema Individual de Geração de Energia Elétrica com Fonte Intermitente - SIGFI. 47 Disponível em: http://www.aneel.gov.br/cedoc/ren2012493.pdf. Acesso em 11 de agosto de 2018.

AGÊNCIA NACIONAL DE ENERGIA ELÉTRICA (ANEEL). Resolução Normativa ${ }^{\circ} 517$, de 11 de dezembro de 2012. Altera a Resolução Normativa $n^{\circ} 482$, de 17 de abril de 2012, e o Módulo 3 dos Procedimentos de Distribuição - PRODIST. Disponível em: http://www.aneel.gov.br/cedoc/ren2012517.pdf. Acesso em 11 de agosto de 2018.

AGÊNCIA NACIONAL DE ENERGIA ELÉTRICA (ANEEL). Resolução Normativa nº 77, de 18 de agosto de 2004. Estabelece os procedimentos vinculados à redução das tarifas de uso dos sistemas elétricos de transmissão e de distribuição, para empreendimentos hidroelétricos e aqueles com base em fonte solar, eólica, biomassa ou cogeração qualificada, cuja potência injetada nos sistemas de transmissão e distribuição seja menor ou igual a $30.000 \mathrm{~kW}$. Disponível em: http://www.aneel.gov.br/cedoc/bren2004077.pdf. Acesso em 28 de abril de 2018. 
AGÊNCIA NACIONAL DE ENERGIA ELÉTRICA (ANEEL). ANEEL - ANEEL abre audiência pública para analisar revisão de regras para geração distribuída. 22 de Janeiro, 2019. Disponível $\quad<\quad$ http://www.aneel.gov.br/sala-de-imprensa-exibicao//asset_publisher/XGPXSqdMFHrE/content/aneel-abre-audiencia-publica-para-analisarrevisao-de-regras-para-geracao-distribuida/656877>. Acesso em: 20/09/2019.

ARAUJO, S.M.V.G - Licenciamento Ambiental e Legislação. Biblioteca Digital Câmera dos Deputados, 2002. Acesso em: 31 de março de 2019.

ATLAS BRASILEIRO DE ENERGIA SOLAR - $2^{\mathrm{a}}$ edição - São José dos Campos: INPE, 2017. Acesso em: 29 de agosto de 2019.

\section{AUSTRALIA ENVIRONMENTAL LEGISLATION LICENSES AND PERMITS DEPARTMENT OF INDUSTRY, INNOVATION AND SCIENCE. Disponível em: https://www.business.gov.au/riskmanagement/environmental-impact/environmental- management/environmentallegislation-licences-and-permits.}

BARBOSA, V. Os 10 países que mais usam energia solar no mundo. Exame. Av. das Nações Unidas, 7221, São Paulo - SP, 28 de novembro de 2012.

Disponível em: < http://exame.abril.com.br/economia/noticias/os-10-paises-que-mais-usamenergia-solar-no-mundo>. Acesso em: 11 de agosto de 2018.

BARBOSA FILHO, W.P.; FERREIRA, W.R.; AZEVEDO, A.C.S.; COSTA, A.L.C.; PINHEIRO, R.B. (2015) Expansão da Energia Solar Fotovoltaica no Brasil: Impactos Ambientais e Políticas Públicas. Gestão e Sustentabilidade Ambiental, Florianópolis, n. esp., p. 628-642.

BRASIL. Lei Federal n ${ }^{\circ}$ 6.938, de 31 de agosto de 1981. Dispõe sobre a Política Nacional do Meio Ambiente, seus fins e mecanismos de formulação e aplicação, e dá outras providências. Disponível em:<http://www.planalto.gov.br/ccivil_03/leis/L6938.htm>. Acesso em 16 de março de 2019. 
BRASIL. Constituição (1988). Constituição da República Federativa do Brasil: promulgada em 5 de outubro de $1988 . \quad$ Disponível em: http://www.planalto.gov.br/ccivil_03/constituicao/constituicaocompilado.htm. Acesso em 16 de março de 2019.

BRASIL. Decreto $n^{\circ} 4.212$, de 26 de abril de 2012. Define os setores da economia prioritários para o desenvolvimento regional, nas áreas de atuação da extinta SUDAM, e dá outras providências. Disponível em: http://www.planalto.gov.br/ccivil_03/decreto/2002/d4212.htm. Acesso em 11 de agosto de abril de 2018.

BRASIL. Decreto n ${ }^{\circ} 4.213$, de 26 de abril de 2012. Define os setores da economia prioritários para o desenvolvimento regional, nas áreas de atuação da extinta SUDENE, e dá outras providências. Disponível em: http://www.planalto.gov.br/ccivil_03/decreto/2002/d4213.htm. Acesso em 28 de abril de 2018.

BRASIL. Decreto $n^{\circ} 7.343$, de 26 de outubro de 2010. Regulamenta a Lei $n^{\circ} 12.114$, de 9 de dezembro de 2009, que cria o Fundo Nacional sobre Mudança do Clima - FNMC, e dá outras providências. Disponível em: http://www.planalto.gov.br/ccivil_03/_Ato20072010/2010/Decreto/D7343.htm. Acesso em 15 de maço de 2018.

BRASIL. Decreto $n^{\circ}$ 7.603, de 9 de novembro de 2011. Regulamenta as condições para aprovação dos projetos de investimento considerados como prioritários na área de infraestrutura ou de produção econômica intensiva em pesquisa, desenvolvimento e inovação, para efeito do art. $2^{\circ}$ da Lei $\mathrm{n}^{\circ}$ 12.431, de 24 de junho de 2011, e dá outras providências. Disponível em: http://www.planalto.gov.br/ccivil_03/_ato2011-2014/2011/decreto/d7603.htm. Acesso em 23 de fevereiro de 2019.

BRASIL. Lei Complementar $n^{\circ}$ 87, de 13 de setembro de 1996. Dispõe sobre o imposto dos Estados e do Distrito Federal sobre operações relativas à circulação de mercadorias e sobre prestações de serviços de transporte interestadual e intermunicipal e de comunicação, e dá outras providências. Disponível em: http://www.planalto.gov.br/ccivil_03/leis/lcp/lcp87.htm. Acesso em 28 de abril de 2018. 
BRASIL. Lei $\mathrm{n}^{\mathrm{o}}$ 11.077, de 30 de dezembro de 2004. Altera a Lei ${ }^{\circ} 8.248$, de 23 de outubro de 1991, a Lei no 8.387, de 30 de dezembro de 1991, e a Lei no 10.176, de 11 de janeiro de 2001, dispondo sobre a capacitação e competitividade do setor de informática e automação e dá outras providências. Disponível em: http://www.planalto.gov.br/ccivil_03/leis/18248.htm. Acesso em 19 de abril de 2018.

BRASIL. Lei $\mathrm{n}^{\mathrm{o}}$ 12.114, de 9 de dezembro de 2009. Cria o Fundo Nacional sobre Mudança do Clima, altera os arts. $6^{\circ}$ o e 50 da Lei ${ }^{\circ} 9.478$, de 6 de agosto de 1997 , e dá outras providências. Disponível em: http://www.planalto.gov.br/ccivil_03/_Ato2007- 2010/2009/Lei/L12114.htm. Acesso em 28 de abril de 2018.

BRASIL. Lei $\mathrm{n}^{\mathrm{o}}$ 12.212, de 20 de janeiro de 2010. Dispõe sobre a Tarifa Social de Energia Elétrica; altera as Leis $n^{\circ}$ s 9.991, de 24 de julho de 2000, 10.925, de 23 de julho de 2004, e 10.438, de 26 de abril de 2002; e dá outras providências. Disponível em https://www.planalto.gov.br/ccivil_03/_Ato2007-2010/2010/Lei/L12212.htm. Acesso 28 de abril de 2018.

BRASIL. Lei n ${ }^{\circ}$ 9.991, de 24 de julho de 2000. Dispõe sobre realização de investimentos em pesquisa e desenvolvimento e em eficiência energética por parte das empresas concessionárias, permissionárias e autorizadas do setor de energia elétrica, e dá outras providências. Disponível em: http://www.planalto.gov.br/ccivil_03/leis/19991.htm. Acesso em 28 de abril de 2018.

BRASIL. Projeto de Lei do Senado $n^{\circ}$ 167, de 2013. Reduz alíquotas de tributos incidentes em painéis fotovoltaicos e similares. Disponível em: http://www.senado.leg.br/atividade/materia/detalhes.asp?p_cod_mate=112612. Acesso em 20 de outubro de 2018.

BRASIL. Projeto de Lei do Senado n ${ }^{\circ} 204$, de 2014. Altera a Lei $n^{\circ} 9.991$, de 24 de julho de 2000, para incluir a microgeração distribuição distribuída no percentual mínimo obrigatório de aplicação de recursos em projetos de eficiência energética pelas concessionárias e permissionárias de distribuição de energia elétrica. Disponível em: http://www.senado.leg.br/atividade/materia/detalhes.asp?p_cod_mate=118046. Acesso em 20 de outubro de 2018. 
BRASIL. Projeto de Lei do Senado n ${ }^{\circ}$ 249, de 2014. Altera a Lei Complementar $n^{\circ}$ 87, de 13 de setembro de 1996, para determinar a não incidência do imposto sobre operações relativas à circulação de mercadorias e sobre prestações de serviços de transporte interestadual e intermunicipal e de comunicação relativo a operações de compensação de energia elétrica que especifica. Disponível em: http://www.senado.leg.br/atividade/materia/detalhes.asp?p_cod_mate=118448. Acesso em 20 de outubro de 2018.

BRASIL. Projeto de Lei do Senado $n^{\circ} 317$, de 2013. Isenta do Imposto sobre a Importação os equipamentos e componentes de geração elétrica de fonte solar. Disponível em: http://www.senado.leg.br/atividade/materia/detalhes.asp?p_cod_mate=113843. Acesso em 20 de outubro de 2018.

BRASIL. Resolução CONAMA Nº 001, de 23 de janeiro de 1986. Dispõe sobre critérios básicos e diretrizes gerais para a avaliação de impacto ambiental. Disponível em: $<$ http://www.mma.gov.br/port/conama/res/res86/res0186.html $>$. Acesso em 30 de março de 2019.

BRASIL. Resolução CONAMA n 237, de 19 de dezembro de 1997. Regulamenta os aspectos de licenciamento ambiental estabelecidos na Política Nacional do Meio Ambiente. Disponível em: <http://www.mma.gov.br/port/conama/res/res97/res23797.html>. Acesso em 23 de março de 2019 .

BRASIL. Resolução CONAMA n 279, de 27 de julho de 2001. Estabelece procedimentos para o licenciamento ambiental simplificado de empreendimentos elétricos com pequeno potencial de impacto ambiental. Disponível em: $<$ http://www.mma.gov.br/port/conama/legiabre.cfm?codlegi=277> . Acesso em 23 de março de 2019.

BRYANSKY, N., SALSMAN, J., RIDGE, S., 2018. Environmental aspects of wind and solar projects in alberta. Bennett jones. Available at: https://www.bennettjones.com/en/ BlogsSection/Environmental-Aspects-of-Wind-and-Solar-Projects-inAlberta?utm_source=Mondaq\&utm_medium=syndication\&utm_campaign=View-. 
CABRAL, I. S.; TORRES, A. C.; SENNA, P. R. - Energia Solar - Análise Comparativa entre Brasil e Alemanha. IBEAS - Instituto Brasileiro de Estudos Ambientais - IV Congresso Brasileiro de Gestão Ambiental Salvador/BA - 25 a 28/11/2013. Disponível em: < http://www.ibeas.org.br/congresso/Trabalhos2013/X-009.pdf $>$. Acesso em: Acesso em: 28 de abril de 2018.

CAIXA Econômica Federal (Brasil). O que é o Construcard. 2015. Disponível em: $<$ http://www.caixa.gov.br/voce/cartoes/casa/construcard/Paginas/default.aspx $>$ Acesso em: 28 de abril de 2018 .

CANAL ENERGIA - Dominado por solar, leilão A-4 termina com contratação de 228,7 MW médios - $2017 . \quad$ Disponível em: < https://www.canalenergia.com.br/noticias/53045554/dominado-por-solar-leilao-a-4-terminacom-contratacao-de-2287-mw-medios>, Acesso em 17 de março de 2019.

CÂMARA DE COMERCIALIZAÇÃO DE ENERGIA ELÉTRICA (CCEE). InfoLeilão nº 009 - $6^{\circ}$ Leilão de Energia de Reserva - 31 de outubro de 2014. São Paulo, 2014. Disponível em: http://www.ccee.org.br/portal/faces/acesso_rapido_header_publico_nao_logado/bibliote ca_virtual?tipo $=$ Boletim\&assunto $=$ Leil\%C3\%A3o\&_afrLoop $=1514864233598126 \# \% 4$ 0\%3F_afrLoop\%3D1514864233598126\%26tipo\%3DBoletim\%26assunto\%3DLeil\%25 C3\%25A3o\%26_adf.ctrl-state\%3Df11bvwq0q_79. Acesso em 28 de abril de 2018.

CÂMARA DE COMERCIALIZAÇÃO DE ENERGIA ELÉTRICA (CCEE). 20 Anos do Mercado Brasileiro de Energia Elétrica - Edição CCEE, São Paulo, 2018.

CARVALHO, R. L. - Proteção ao meio ambiente, uma prioridade alemã. Revista da Faculdade de Direito da UFRGS, v. 15, 1998.

CENTRO DE PESQUISAS DE ENERGIA ELÉTRICA - CEPEL - ELETROBRAS. As energias solar e eólica no Brasil. Rio de Janeiro, RJ, 2013. Disponível em: http://www.cresesb.cepel.br/download/casasolar/casasolar2013.pdf. Acesso em: 28 de abril de 2018. 
CEPEL - CRESESB - Manual de Engenharia para Sistemas Fotovoltaicos. Rio de Janeiro, RJ, 2014. Disponível em: http://www.redemulhersustentabilidade.org.br/Acervo/Manual_de_Engenharia_FV_2014.pdf. Acesso em: 11 de agosto de 2018.

CHINA, 1989. Environmental Protection Law of the People's Republic of China.

CHINA, 2003. Law of the People's Republic of China on Environmental Impact Assessment.

CHIQUITO, A. J. - Pontos Quânticos: átomos artificiais e transistores atômicos. Rev. Bras. Ensino Fís. vol.23 no.2 São Paulo June 2001. Acesso em: 21 de setembro de 2018.

CONECTE - Guia de procedimentos para mitigação de efeitos de rodovias sobre a fauna, 2012. Disponível em: <https://www.conecte.bio.br/lic_etp.html>. Acesso em: 30 de junho de 2019.

CONJUR/MMA. PARECER N 312 de 2004. Conflito de competência para licenciamento ambiental. Disponível em: $<$ https://www.google.com.br/url?sa=t\&rct=j\&q=\&esrc=s\&source=web\&cd=1\&ved=0CB4QF jAA\&url=http $\% 3 \mathrm{~A} \% 2 \mathrm{~F} \% 2 \mathrm{Fwww.ibama.gov.br} \% 2 \mathrm{Flicenciamento} \% 2 \mathrm{Fmodulos} \% 2 \mathrm{Farquivo.p}$ hp\%3Fcod_arqweb\%3Dpar312\&ei=4L6UVamzOoingwTM0IOYAw\&usg=AFQjCNGX3Mm KR7jcIUm34bDTrmjd_KOoug\&sig2=I0DBYirHgnMVvcLq3iWQ8g\&bvm=bv.96952980,d.e $\mathrm{XY} \& \mathrm{cad}=\mathrm{rja}>$. Acesso em 21 de janeiro de 2020.

CONSELHO DELIBERATIVO DO DESENVOLVIMENTO DO CENTRO-OESTE (CONDEL/SUDECO). Resolução $\mathrm{n}^{\mathrm{o}}$ 016, 6 de setembro de 2013. FUNDO DE DESENVOLVIMENTO DO CENTRO-OESTE (FDCO) - Diretrizes e Prioridades para 2014. Disponível em: http://www.sudeco.gov.br/documents/10157/175907/Anexo+09++ Diretrizes + e+Prioridades+do+FDCO+para+2014.pdf. Acesso em 28 de abril de 2018.

CONSELHO NACIONAL DE POLÍTICA FAZENDÁRIA (CONFAZ). Convênio ICMS nº 101, de 12 de dezembro de 1997. Concede isenção do ICMS nas operações com equipamentos e componentes para o aproveitamento das energias solar e eólica que especifica. Disponível em: http://www1.fazenda.gov.br/confaz/confaz/convenios/ICMS/1997/CV101_97.htm. Acesso em 21 de setembro de 2018. 
CONSELHO NACIONAL DE POLÍTICA FAZENDÁRIA (CONFAZ). Convênio ICMS nº, de 5 de abril de 2013. Estabelece disciplina para fins da emissão de documentos fiscais nas operações internas relativas à circulação de energia elétrica, sujeitas a faturamento sob o Sistema de Compensação de Energia Elétrica de que trata a Resolução Normativa No 482/2012, da Agência Nacional de Energia Elétrica - ANEEL. Disponível em: http://www1.fazenda.gov.br/confaz/confaz/Convenios/ICMS/2013/CV006_13.htm. Acesso em 21 de setembro de 2018.

CRESESB - Centro de Referência para Energia Solar e Eólica Sérgio de Salvo Brito, Disponível em: < http://www.cresesb.cepel.br>. Acesso em: 28 de abril de 2018.

CRUZ, V. O. R. - Avaliação das alterações ambientais ocasionadas por usinas solares fotovoltaicas no Ceará. Universidade Federal Rural do Rio de Janeiro - Instituto Três Rios. Três Rios - RJ - dezembro de 2018.

DAUKES, N. J. E. - Solar Energy for heat and electricity: the potential for mitigating climate change. Grantham Institute for Climate Change - Briefing paper $n^{\circ} 1,2009$ - Imperial College, London. Acesso em: 28 de abril de 2018.

DERÍSIO, J. C. Introdução ao controle de poluição ambiental. 2a Edição. São Paulo: Signus, 2000.

DINIZ, M. H. Compêndio da introdução à ciência do direito. São Paulo : Saraiva, 2008.

EM DISCUSSÃO - SENADO FEDERAL - O desafio da energia: Saídas para a geração de eletricidade. Ano 6 - $\mathrm{N}^{\mathrm{o}} 25$ - junho de 2015. Disponível em: $<$ https://www12.senado.leg.br/emdiscussao/edicoes/o-desafio-da-energia $>$

EMPRESA DE PESQUISA ENERGÉTICA (EPE). Análise da Inserção da Geração Solar na Matriz Elétrica Brasileira. Rio de Janeiro, maio/2012 (Nota Técnica). Disponível em: http://www.epe.gov.br/geracao/Documents/Estudos_23/NT_EnergiaSolar_2012.pdf. Acesso em 28 de abril de 2018. 
EMPRESA DE PESQUISA ENERGÉTICA (EPE). Nota Técnica DEA 19/14 - Inserção da Geração Fotovoltaica Distribuída no Brasil - Condicionantes e Impactos. Rio de Janeiro, outubro/2014. Disponível em: http://www.epe.gov.br/mercado/Documents/S\%C3\%A9rie\%20Estudos\%20de\%20Ener gia/DEA\%2019\%20\%20\%20Inser\%C3\%A7\%C3\%A3o\%20da\%20Gera\%C3\%A7\%C3\%A3o\%20Fotovoltai ca\%20Distribu\%C3\%ADda\%20no\%20Brasil\%20-

\%20Condicionantes\%20e\%20Impactos\%20VF\%20\%20\%28Revisada\%29.pdf. Acesso em 28 de abril de 2018.

ESPOSITO, A.S.; FUCHS, P.G. - Desenvolvimento tecnológico e inserção da energia solar no Brasil. Revista do BNDES, v. 40, dez/2013, pp. 85-114. Disponível em: http://www.bndes.gov.br/SiteBNDES/export/sites/default/bndes_pt/Galerias/Arquivos/c onhecimento/revista/rev4003.pdf. Acesso em 28 de abril de 2018.

EXAME - Conheça Fujisawa, a cidade verde e inteligente. Disponível em: http://exame.abril.com.br/tecnologia/conheca-fujisawa-a-cidade-verde-e-inteligente-dojapao/\#1. Acesso em: 28 de abril de 2018.

FERREIRA, W.R.; BARBOSA FILHO, W.P.; SILVA, L.M.L.; AZEVEDO, A.C.S. (2016) Levantamento de Impactos Ambientais na construção e operação de usinas Heliotérmicas. In: CONGRESSO BRASILEIRO DE PLANEJAMENTO ENERGÉTICO, 10., 2016. Anais... Gramado.

FIORILLO, C. A. P. Curso de direito ambiental brasileiro. 6. Ed. São Paulo: Saraiva, 2005.

GALDINO, M. A. \& LIMA, J. H. G. PRODEEM - O Programa Nacional de Eletrificação Rural Baseado em Energia Solar Fotovoltaica. CEPEL - Centro de Pesquisas de Energia Elétrica. Congresso Brasileiro de Energia, 2002.

GLASSON, J., THERIVEL, R., CHADWICH, A., 2005. Introduction to Environmental Assessment, third ed. Taylor \& Francis Group, London \& New Work. 
GOMES, F. F.; SILVA, C. L. - O conflito resultante do licenciamento ambiental: o cenário das pequenas centrais hidrelétricas no Paraná - Universidade Tecnológica Federal do Paraná (UTFPR), Curitiba, Paraná, Brasil - INTERAÇÕES, Campo Grande, MS, v. 18, n. 4, p. 155168, out./dez. 2017.

HENRIQUES, A. R. S. - Previsão de Potencial de Mercados Emergentes de Tecnologia Fotovoltaica. Faculdade de Economia - Universidade do Porto, Portugal, 2012. Acesso em: 28 de abril de 2018.

HG Legal Resources. Environmental and Natural Resources Law. 2013. Disponível em: < http://www.hg.org/environ.html >.

HOFFMANN, A.S.; CARVALHO, G. H.; JR, R.A.F.C - Environmental licensing challenges for the implementation of photovoltaic solar energy projects in Brazil. Energy Policy 132 (2019) $1143-1154$.

IBAMA - Instituto Brasileiro do Meio Ambiente e dos Recursos Naturais. Edital No 1, de 25 de Outubro de 2012. Concurso Público para Provimento de Vagas no Cargo de Analista Ambiental. Disponível em: $<$ http://www.cespe.unb.br/concursos/ibama_12_analista_ambiental/arquivos/ed_1_2012_iba ma_analista_abt.pdf>

IBAMA - INSTITUTO BRASILEIRO DO MEIO AMBIENTE E DOS RECURSOS NATURAIS. Disponível em: <http://www.ibama.gov.br.>

INSTITUTO DE ENERGIA E AMBIENTE - Universidade de São Paulo. História. Disponível em: http://www.iee.usp.br/?q=pt-br/institucional/hist\%C3\%B3ria. Acesso em: 28 de abril de 2018.

INSTITUTO DE ENERGIA E AMBIENTE - Universidade de São Paulo. Projeto de Pesquisa e Desenvolvimento (PD-0068-0029/2011). Acesso em: 17 de setembro de 2017.

JUNIOR, A. A. Noções de direito e direito internacional. Brasília : Fundação Alexandre de Gusmão, 2012. 242 p. 
LUQUE, A.; HEGEDUS S. Handbook of Photovoltaic Science and Engineering. 2. ed. Chichester: John Wiley and Sons, 2011. 1168 p.

MACHADO, P. A. L. Direito ambiental brasileiro. 13 ed. rev. atual e ampl São Paulo: Malheiros, 2005.

MACHADO, C. T.; MIRANDA, F. S. - Energia Solar Fotovoltaica: Uma Breve Revisão. Rev. Virtual Quim., 2015, 7 (1), p. 126-143, 2014. Acesso em: 18 de agosto de 2017.

MARIANO, J.D.; SANTOS, F.R.; BRITO, G.W.; URBANETZ JR., J.; CASAGRANDE JUNIOR, E.F. (2016) Hydro, thermal and photovoltaic power plants: A comparison between electric power generation, environmental impacts and $\mathrm{CO} 2$ emissions in the Brazilian scenario. International Journal of Energy and Environment, v. 7, n. 4, p. 347-356.

MARKVART, T. e CASTANER, L. Overview of Potential Hazards. Practical Handbook of Photovoltaics: Fundamentals and Applications. New York :Elsevier, 2003.

MARTIN, N., RICE, J., 2015. Improving Australia's renewable energy project policy and planing: a multiple stakeholder analysis. Energy Policy 84, 128-141.

MATSUMOTO, A. - Desenvolvimento de Células Fotovoltaicas Orgânicas e Flexíveis. Universidade de Campinas, 2013. Acesso em: 17 de setembro de 2017.

MCCRARY, M.D.; MCKERNAN, P.A.F.; WAGNER, W.D. (1984) Wildlife interactions at solar one: final report. Rosemead: Southern California Edison.

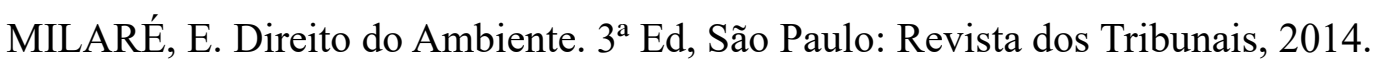

MINISTÉRIO DO MEIO AMBIENTE. Parecer 312 CONJUR. IBAMA, 2004. Disponível em: $<$ http://www.ibama.gov.br/licenciamento/>.

MINISTÉRIO PÚBLICO FEDERAL. Deficiências em estudos de impacto ambiental: síntese de uma experiência. Brasília: Ministério Público Federal, 4 a Câmara de Coordenação e Revisão, 2004. 38 p. 
MMA Ministério do Meio Ambiente. Resolução no 237 de 19 de dezembro de 1997. Disponível em: < http://www2.mma.gov.br/port/conama/res/res97/res23797.html>. Acesso em 16 de março de 2019.

MME. Ministério de Minas e Energia. Relatório Sumário Executivo das Atividades Desenvolvidas pelo Programa de Desenvolvimento Energético de Estados e Municípios (PRODEEM). Período de jun 2003 - dez 2004. Janeiro 2005. Programa de Incentivo as Fontes Alternativas de Energia Elétrica - PROINFA. Disponível em:< http://www.mme.gov.br/programs_display>. Acesso em: 18 de agosto de 2018.

MME. Ministério de Minas e Energia. Plano Nacional de Energia 2030. Disponível em< http://www.epe.gov.br/PNE/20080512_3.pdf>. Acesso em 18 de agosto de 2018.

MME. Ministério de Minas e Energia. Eólicas têm papel fundamental no compromisso do Brasil na COP 21, diz Azevedo. Disponível em:< http://www.mme.gov.br/web/guest/paginainicial/outras-noticas/-/asset_publisher/32hLrOzMKwWb/content/eolicas-tem-papelfundamental-no-compromisso-do-brasil-na-cop-21-diz-azevedo >. Acesso em: 28 de abril de 2018.

MOCELIN, A. R. - Qualificação Profissional e Capacitação Laboratorial em Sistemas Fotovoltaicos. Universidade de São Paulo, SP, 2014. Acesso em: 17 de setembro de 2018.

MONTEIRO, J. M. B. M - Aplicações de Energia Solar em Meio Urbano. Faculdade de Engenharia da Universidade do Porto, Lisboa - Portugal, janeiro de 2005. Acesso em: 17 de setembro de 2018.

MONTENEGRO, S. BNDES pode emprestar para distribuidoras e instaladoras para projetos de microgeração. Canal Energia. Rio de Janeiro, 10 abr. 2014. Investimentos e Finanças. Disponível em: http://www.canalenergia.com.br/zpublisher/materias/Newsletter.asp?id=100611\#. Acesso em 28 de abril de 2018.

MULVANEY, D., et al. Toward a Just and Sustainable Solar Energy Industry. United States : Silicon Valley Toxics Coalition. 2009. 45 p. 
NAKABAYASHI, R. K. - Microgeração Fotovoltaica no Brasil: condições atuais e perspectivas futuras. Universidade de São Paulo, USP - Instituto de Energia e Ambiente, 2014. Acesso em: 17 de setembro de 2017.

NIEDHARDT, J. T. - Novas Perspectivas para a Energia Solar no Brasil. Lavras - MG, 2009. Acesso em: 17 de setembro de 2018.

ABRACEEL - Associação Brasileira dos Comercializadores de Energia. Cartilha: Mercado Livre de Energia Elétrica - um guia básico para consumidores potencialmente livres e especiais, 2016.

OLIVEIRA, C.M.F.V - Licenciamento Ambiental. Universidade Federal do Rio Grande do Sul - Curso de Pós-Graduação em Direito, 2012. Acesso em: 31 de março de 2019.

ONTARIO, 2018. Ministry of energy. Guide to provincial approvals for renewable energy projects. Available at. http://www.energy.gov.on.ca/en/renewable-energyfacilitationoffice/Ontarioresources-and-contacts-2/guide-to-provincial-approvalsfor-renewable-energyprojects/.

PERAZZOLI, D. L.; GOBBI, E. F.; TIEPOLO, G. M. Proposta de critérios norteadores e requisitos mínimos para licenciamento ambiental de usinas fotovoltaicas no Brasil. Eng. Sanit. Ambient. vol.25 no.2 Rio de Janeiro Mar./Apr. 2020 Epub Apr 17, 2020. Acesso em maio de 2020.

PERCIVAL, R. V. - The EPA as a Catalyst for the Development of Global Environmental Law, 70 Case W. Res. L. Rev. 1151 (2020)

PEREIRA, E. B., et al. Atlas brasileiro de energia solar.; 2. Ed. - São José dos Campos: INPE, 2017.; 88p.: Il.(E_BOOK).; ISBN 978-85-17-00089-8. Acesso em maio de 2020.

PEREIRA, N. X. - Desafios e Perspectivas da Energia Solar Fotovoltaica no Brasil: Geração Distribuída vs Geração Centralizada. Universidade Estadual Paulista "Júlio de Mesquita Filho" - UNESP - Curso de Pós Graduação em Ciências Ambientais, 2019. Acesso em maio de 2020. 
PORTAL SOLAR - Energia Solar no Brasil Cresceu 70\% em apenas 2 anos. Disponível em: http://www.portalsolar.com.br/blog-solar/energia-solar/energia-solar-no-brasil-cresceu-70-emapenas-2-anos. Acesso em 28 de abril de 2018.

PORTAL SOLAR - China alcança novo recorde mundial em energia solar. Disponível em: http://www.portalsolar.com.br/blog-solar/energia-solar/china-alcanca-novo-recorde-mundialem-energia-solar.html. Acesso em: 28 de abril de 2018.

PORTO, L. Comunicação via e-mail. Diretora do Departamento de Desenvolvimento Energético e Coordenadora da Sala de Monitoramento do PROINFA. Novembro 2007. Acesso em: 28 de abril de 2018.

PROJETO DE LEI FEDERAL No 1.563. Dispõe sobre fontes renováveis de energia, com o objetivo de promover a universalização, a geração distribuída e a racionalização energética, e altera a Lei $\mathrm{n}^{\mathrm{o}} 10.438$, de 26 de abril de 2002, para modificar o Proinfa e aumentar a participação de fontes alternativas na matriz energética nacional. S/D, 2007. Acesso em: 11 de agosto de 2018.

REIS, D. C. - Análise crítica do processo de licenciamento ambiental de usinas fotovoltaicas. Programa de Pós-Graduação em Energia Elétrica da Universidade Federal de Minas Gerais Belo Horizonte, MG - 2015. Acesso em 17 de setembro de 2017.

REN21. 2015 - Renewables 2015 Global Report. Paris, France.

REN21. 2016 - Renewables 2016 Global Report. Paris, France.

REN21. 2017 - Renewables 2017 Global Report. Paris, France.

REN21. 2018 - Renewables 2018 Global Report. Paris, France.

REN21. 2019 - Renewables 2019 Global Report. Paris, France. 
REVISTA PESQUISA FAPESP - Edição 258 - Agosto de 2017. Disponível em: $<$ http://revistapesquisa.fapesp.br/2017/08/18/para-aproveitar-o-sol/?cat=politica $>$. Acesso em 31 de março de 2019.

ROMANZOTI, N. - Usina de Energia Solar: conheça a maior do mundo. Hype Science, 16 de fevereiro de 2014. Disponível em: http://hypescience.com/usina-de-energia-solar/. Acesso em: 28 de abril de 2018.

ROSA, D. J. M. - Caracterização da Radiação Solar: O Caso da Cidade Universitária/USP e a Ilha do Cardoso/Cananéia. Universidade de São Paulo - Programa Interunidades de PósGraduação em Energia PIPGE-USP (EP/FEA/IEE/IF), 2003. Acesso em: 28 de abril de 2018.

ROSA, A. R. O.; GASPARIN, F. P. - Panorama da Energia Solar Fotovoltaica no Brasil. Revista Brasileira de Energia Solar- Ano 7, vol. VII, n², dezembro de 2016, p. 140 - 147. Acesso em: 17 de setembro de 2017.

\section{SECRETARIA DE ASSUNTOS ESTRATÉGICOS PRESIDÊNCIA DA REPÚBLICA. Licenciamento ambiental. Disponível} em: $<$ http://www.law.harvard.edu/faculty/unger/portuguese/pdfs/11_Licenciamento_ambiental 1.pdf $>$. Acesso em: 16 de março de 2019.

SENADO FEDERAL. O Desafio da Energia - Saídas para a Geração de Eletricidade. Revista "Em Discussão", no 25.

SILVA, R. M. - Energia Solar no Brasil: dos incentivos aos desafios. 2015. Disponível em: $<$ http://www12.senado.leg.br/publicacoes/estudos-legislativos/tipos-de-estudos/textos-paradiscussao/td166>. Acesso em: 14 de abril de 2018.

SIRVINSKAS, L. P. - Manual do Direito Ambiental - 16 ed. São Paulo, Saraiva Educação, 2018. Acesso em 16 de março de 2019.

SOLAR ENERGY DEVELOPMENT PROGRAMMATIC EIS SOLAR PEIS. Disponível em: http://solareis.anl.gov/ 
THE GREENEST POST. MIWA, Jessica. Coréia do Sul produz energia solar. Disponível em: Acesso em: 28 de abril de 2018.

TCU - Tribunal de Contas da União. TC 009.362/2009-4 Relatório de Levantamento de Auditoria no IBAMA - avaliação dos instrumentos de controle ambiental. 2009. 69 p.

TCU - Tribunal de Contas da União. Cartilha de licenciamento ambiental. 2.ed. Brasília: $4^{\mathrm{a}}$ Secretaria de Controle Externo, 2007. 83 p.

TCU - Tribunal de Contas da União. Cartilha de licenciamento ambiental. 2.ed. Brasília: $4^{\mathrm{a}}$ Secretaria de Controle Externo, 2007. 83 p.

TEIXEIRA, A. A.; CARVAlHO, M. C.; LEITE, L. H. M. - Análise de Viabilidade para a Implantação do Sistema de Energia Solar Residencial. e-xacta, Belo Horizonte, v. 4, n. 3, p. 117-136. (2011). Editora UniBH. Disponível em: <www.unibh.br/revistas/exacta/>. Acesso em: 28 de abril de 2018.

TURNEY, D.; FTHENAKIS, V. (2011) Environmental impacts from the installation and operation of large-scale solar power plants. Renewable and Sustainable Energy Reviews, v. 15, p. 3261-3270. https://doi.org/10.1016/j.rser.2011.04.023. Acesso em maio de 2020.

VARELLA, F. K. O. M.; CAVALIERO, C. K. N.; SILVA, E. P. - Energia Solar Fotovoltaica no Brasil: Incentivos Regulatórios. Revista Brasileira de Energia, Vol. 14, No . 1, 1o Sem. 2008, pp. 9-22. Disponível em: $\quad<$ http://new.sbpe.org.br/wpcontent/themes/sbpe/img/artigos_pdf/v14n01/v14n01a1.pdf $>$. Acesso em: 7 de abril de 2018.

VIANELLO, R. L.; ALVES, A. R. Meteorologia básica e aplicações $2^{\mathrm{a}}$ Edição. Viçosa:UFV, 2013. ISBN: 9788572694322. VICHI, Flavio Maron \& MANSOR, Maria Teresa Castilho.; Energia, meio ambiente e economia: o Brasil no contexto mundial,; Quím. Nova, v..32 n. 3 São Paulo 2009 SciElo. Disponível em: http://www.scielo.br/scielo.php?script=sci_arttext\&pid=S0100- 40422009000300019. Acesso em maio de 2020. 
VITORETI, A. B. F. et al.. Células solares sensibilizadas por pontos quânticos. Quim. Nova, Vol. 40, No. 4, 436-446, 2017. Acesso em: 28 de abril de 2018.

VULCANIS, A. Os problemas do Licenciamento Ambiental e a Reforma do Instrumento. In: $14^{\circ}$ Congresso Internacional de Direito Ambiental, 2010, São Paulo. Florestas, Mudanças Climáticas e Serviços Ecológicos. Anais. São Paulo: Imprensa Oficial do Estado de São Paulo, 2010. v. 1. p. $27-42$

WANG, Y., MORGANB, R.K., CASHMORE, M., 2003. Environmental impact assesment of projects in the People's Republic of China: new law, old problems. In: Environmental Impact Assessment Review. vol. 23. ELSEVIER, pp. 543-579.

ZILLES, R. - Energia Solar Fotovoltaica. Instituto de Eletrotécnica e Energia da Universidade de São Paulo (USP), São Paulo, SP, 2012. Cap 13 - pg 116-120. Disponível em: $<$ http://ws1.iee.usp.br/biblioteca/producao/2012/Livros/zillesenergiasolar.pdf $>$. Acesso em: 7 de abril de 2018. 


\section{APÊNDICE}

\section{APÊNDICE A - Roteiro para Elaboração de Estudos Ambientais}

1. Introdução

Como conteúdo introdutório é importante descrever, de modo geral, o empreendimento, ressaltando o contexto em que se insere, utilizando-se assim de ilustração em carta topográfica IBGE em escala de 1:50.000 ou maior, assim como requisitos para o licenciamento e o estudo a ser elaborado.

2. Informações Gerais

É necessário que se destaque o objetivo do licenciamento, os dados do empreendedor e do responsável por elaborar o estudo ambiental.

\subsection{Objetivo do Licenciamento}

Deve-se descrever, de maneira resumida, o objeto do licenciamento, assim como os aspectos que caracterizam o empreendimento, como nome, instalações, descrição de obras (informando áreas ocupadas, extensão etc.) e equipamentos a serem utilizados. Os dados mais detalhados do empreendimento são dispostos na descrição do projeto que constará a licença ambiental.

\subsection{Empreendedor}

Apresentação de dados do empreendedor referentes ao projeto (as informações devem ser sempre atualizadas caso haja alterações), como:

- Razão social;

- Nome fantasia da empresa;

- CNPJ;

- Endereço; 
- Nome do representante legal;

- Telefone do representante legal;

- E-mail do representante legal;

- Pessoa para contato;

- Telefone da pessoa para contato; e

- E-mail da pessoa para contato.

\subsection{Empresa Responsável pelo Estudo Ambiental}

Apresentação de dados referentes à empresa responsável pela elaboração do estudo ambiental, como:

- Razão social;

- Nome fantasia da empresa

- Endereço;

- CNPJ;

- Nome do representante legal;

- Telefone do representante legal;

- E-mail do representante legal;

- Coordenador do estudo ambiental;

- Telefone do coordenador do estudo ambiental; e 
- E-mail do coordenador do estudo ambiental.

3. Justificativa do Empreendimento

Deve-se apresentar as justificativas econômicas e socioambientais da implantação do empreendimento na região a qual será inserido, assim como o setor a que pertence. A justificativa deve visar o apelo da relevância do projeto, como demanda a ser atendida.

Para os projetos de energia, é interessante destacar que um dos principais indicadores de desenvolvimento econômico e de qualidade de vida é o consumo anual de energia por habitante, de forma que a inserção de por exemplo a usina solar será então vantajosa, já que o índice está ligado à capacidade do habitante de adquirir bens e serviços.

\section{Estudos de Alternativas}

Nesse item, apresentam-se as alternativas tecnológicas e locacionais para implantação do empreendimento, assim como a análise que fundamentou a escolha da alternativa apresentada no estudo ambiental. Para isso, é feita uma análise comparativa, justificando-se técnica, econômica e ambientalmente a alternativa escolhida em relação às demais. Ainda, levando em consideração também os impactos sobre os meios físico, biótico e socioeconômico com as demais alternativas.

É recomendável que os resultados dessas análises comparativas sejam apresentados em forma de quadro e a alternativa escolhida devidamente justificada.

De acordo com a Resolução CONAMA 01/86 (Artigo $5^{\circ}$, inciso I), as alternativas propostas devem ser confrontadas com a hipótese da não execução do projeto.

\subsection{Alternativas Tecnológicas}

Neste item é feita uma análise comparativa quanto às alternativas tecnológicas viáveis do projeto, como estruturas, equipamentos previstos, suas vantagens bem como desvantagens, considerando os aspectos ambientais, técnicos e econômicos. 


\subsection{Alternativas Locacionais}

Com relação às alternativas locacionais, estas resumem-se em diferentes possibilidades de traçado, sítio, e/ou layout para que os objetivos sejam atendidos, além de possibilitar o projeto de ser técnico, ambiental e economicamente viável.

Deve-se incluir na avaliação uma análise comparativa, através do resultado dos indicadores, com escalas de valoração e ponderação, para as alternativas mencionadas.

Para o estudo de locação de usinas fotovoltaicas, devem ser considerados inúmeros fatores, como disponibilidade de insolação no local e o então consequente nível de radiação solar. Ainda, é importante analisar a possibilidade de interligação da usina ao Sistema Brasileiro de transmissão e distribuição de energia.

Por fim, apresenta-se então a composição final das alternativas, destacando a escolhida devidamente justificada.

\section{Aspectos Legais e Institucionais}

Para este item, deve-se apresentar a legislação e normas ambientais que são aplicáveis à tipologia do empreendimento, bem como sua localização, nos âmbitos federal, estadual e municipal, levando em consideração o uso e ocupação do solo e preservação de recursos ambientais e naturais.

Ainda, deve-se informar e avaliar as recomendações, proibições e obrigações, segundo as normas, considerando as atividades a serem desenvolvidas pelo projeto, a área de influência deste e seus ecossistemas, o alcance espacial dos impactos e o processo de licenciamento ambiental.

6. Compatibilidade com Planos, Programas e Projetos Colocalizados

Conforme proposto pelo artigo $5^{\circ}$ da Resolução CONAMA 01/86, neste item descreve-se os planos e programas governamentais dos âmbitos federal, estadual e municipal, assim como projetos públicos e privados propostos em implantação na área de influência do projeto, como 
Planos e Programas de Ordenamento Territorial e Ambiental (uso e ocupação do solo dos municípios, Unidades de Conservação - UC - áreas de proteção de mananciais, Planos Diretores, Planejamento Macroregional etc); Políticas Públicas Ambientais; Compatibilidade com projetos regionais e municipais, interferências com outros projetos a serem instaurados na região e Plano de Bacia Hidrográfica.

Assim, devem ser avaliados possíveis conflitos entre os planos e programas, solucionandoos se possível, caso sejam ocorrentes com alternativas propostas.

\section{Caracterização do Empreendimento}

$\mathrm{Na}$ caracterização do projeto, é apresentada uma imagem por satélite ou foto da área que terá o empreendimento, indicando os limites do mesmo, com todas as instalações, acessos e outras estruturas que tenham relação com a implantação e operação do projeto.

Deve-se caracterizar, com o auxílio de incorporação de plantas, ilustrações e tabelas, o empreendimento, assim como intervenções previstas para sua implantação, incluindo informações especializadas como procedimentos construtivos, além de informações sobre infraestrutura de apoio ao projeto (como canteiro de obras, escritório, alojamentos, estacionamento, área para armazenamento de materiais etc), infraestrutura para frente de obra e canteiros, estimativa de investimento da obra, quantificação dos principais insumos, estimativa de volume envolvido em atividades de terraplanagem e cronograma de implantação etc.

\section{8. Áreas de Influência}

De acordo com o artigo $5^{\circ}$ da Resolução CONAMA 01/86, o Estudo de Impacto Ambiental deve conter a delimitação das áreas de influência do empreendimento a ser implantado, sendo estas diretamente ou indiretamente afetadas pelo mesmo.

São três os limites dessas áreas: 
- Área Diretamente Afetada (ADA) - corresponde à região que sofre ação direta do projeto pela sua implantação. No caso de uma usina fotovoltaica compreende à área onde estão inseridos os painéis fotovoltaicos, ou seja, à área da usina em si.

- Área de Influência Direta (AID) - corresponde à região que sofre os impactos diretos da implantação e operação do projeto, como impactos socioeconômicos por exemplo.

- Área de Influência Indireta (AII) - corresponde à região que sofre impactos indiretos da implantação e operação do projeto.

\section{Diagnóstico Ambiental}

Nesta parte do relatório, é necessário que se avaliem todos os aspectos dos meios físico, biótico e socioeconômico das áreas de influência do projeto, seja na fase de planejamento, implantação e operação.

Em se tratando de informações técnicas, deve ser feito um levantamento de campo ou mesmo consulta de dados secundários na literatura ou outros relatórios.

O nível de detalhamento para cada área de influência pode variar muito, dependendo do empreendimento e seus impactos sobre as regiões.

\section{Identificação e Avaliação de Impactos}

Feitas a caracterização do empreendimento e o diagnóstico ambiental, é necessário que se identifiquem e avaliam os impactos advindos do planejamento, instalação e operação do projeto, com as devidas quantificações e especificações.

Para isso, devem ser apresentados alguns dados, como procedimentos metodológicos adotados, identificação dos aspectos do projeto e fatores ambientais impactados e avaliação dos mesmos. 
Neste item, deve-se apresentar os programas e planos ambientais que contenham medidas preventivas, mitigadoras e/ou compensatórias aos impactos negativos identificados.

Ao apresentar tais programas e planos, os mesmos devem ser separados por fase do projeto, fator ambiental e impacto que destinam.

Além disso, os Programas de Monitoramento são importantes para o acompanhamento dos efeitos reais do projeto sobre o meio ambiente, avaliando se as medidas mitigadoras que foram propostas são de fato eficazes, ajustando-as caso não sejam.

\section{Prognóstico Ambiental}

No prognóstico ambiental, a situação ambiental das áreas de influência é avaliada, de acordo com a implantação e operação do projeto, levando ainda em consideração os planos e programas apresentados.

É importante realizar um comparativo da região na presença e ausência do empreendimento, destacando seus benefícios.

\section{Conclusões}

As conclusões são referentes à viabilidade ambiental do empreendimento, além de algumas considerações feitas relativas à fatores que possam alterar a viabilidade deste.

\section{Referências Bibliográficas}

Toda a bibliografia utilizada para a elaboração do relatório deve ser listada.

\section{Equipe Técnica}

A equipe para um Estudo Ambiental deve ser multidisciplinar habilitada, uma vez que a análise é multidisciplinar. 
Os participantes responsáveis devem ser listados, juntamente com sua formação acadêmica, registro de classe e informar qual parte do estudo foi feito sob sua responsabilidade.

Ainda, é necessário que sejas apresentadas as Anotações de Responsabilidade Técnica ART dos coordenadores de cada equipe de especialistas, de acordo com o $\S 2^{\circ}$ do Artigo 19 Capítulo III, da Lei Estadual no 9509/97. 